$1-1-2017$

\title{
Repeat Players in Multidistrict Litigation: The Social Network
}

Elizabeth Chamblee Burch

Charles H. Kirbo Chair of Law University of Georgia School of Law, eburch@uga.edu

Margaret S. Williams

Charles H. Kirbo Chair of Law Federal Judicial Center

University of Georgia School of Law

Research Paper Series

Paper No. 2016-04

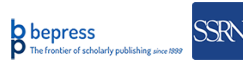

\section{Repository Citation}

Elizabeth Chamblee Burch and Margaret S. Williams, Repeat Players in Multidistrict Litigation: The Social Network, 102 Cornell L. Rev. 1335 (2017),

Available at: https://digitalcommons.law.uga.edu/fac_artchop/1178

This Article is brought to you for free and open access by the Faculty Scholarship at Digital Commons @ University of Georgia School of Law. It has been accepted for inclusion in Scholarly Works by an authorized administrator of Digital Commons @ University of Georgia School of Law. Please share how you have benefited from this access For more information, please contact tstriepe@uga.edu. 


\title{
REPEAT PLAYERS IN MULTIDISTRICT LITIGATION: THE SOCIAL NETWORK
}

\author{
Elizabeth Chamblee Burch $\dagger$ \& Margaret S. Williams $\dagger^{\dagger}$
}

As class certification wanes, plaintiffs' lawyers resolve hundreds of thousands of individual lawsuits through aggregate settlements in multidistrict litigation. But without class actions, formal rules are scarce and judges rarely scrutinize the private agreements that result. Meanwhile, the same principal-agent concerns that plagued class-action attorneys linger. These circumstances are ripe for exploitation: few rules, little oversight, multi-million dollar common-benefit fees, and a push for settlement can tempt a cadre of repeat players to fill in the gaps in ways that further their own self-interest.

Although multidistrict litigation now comprises 36\% of the pending federal civil caseload, legal scholars have offered little sustained theoretical or empirical analysis as to how repeat players' enforcement efforts shape litigation or claims resolution. We wade into this increasingly controversial territory to offer the first comprehensive empirical investigation of private attorneys' efforts in multidistrict leadership on both the plaintiff and defense side. We found that transferee judges regularly appoint the same lead attorneys.

To then uncover what the naked eye cannot see, we employed a social-network analysis to reveal repeat actors' connections to one another. No matter what measure of centrality we used, a key group of attorneys maintained their elite position within the network. This matters considerably, for lead lawyers control the proceeding and negotiate settlements. They can bargain for what may matter to them most: defendants want to end lawsuits, and plaintiffs' lawyers want to

$\dagger$ Charles H. Kirbo Chair of Law, University of Georgia Law School. Our thanks to Christina Boyd, Brannon Denning, Emery Lee, Kay Levine, Jonathan Nash, Adam Zimmerman, anonymous transferee judges, and anonymous multidistrict litigation attorneys, as well as participants at Duke Law School's MassTort MDL Program for Judicial Conference Committees, and Emory/UGA's faculty workshop for their comments on earlier drafts and insights on the topic. Thanks also to Payton Bradford, Hayes Dever, and Kyle Hollomon for their research and data collection assistance, and especially to Georgia School of Law for generously funding this research. With one exception in 2009, Professor Burch has never provided outside consulting or expert witness services. No outside funding or grants have been used to fund our work.

$\dagger \dagger$ Visiting Assistant Professor at Vanderbilt Law School. 
recover for their clients and receive high fee awards along the way.

By identifying settlement provisions that one might argue principally benefit the repeat players, we examined the publicly available nonclass settlements these elite lawyers designed. Over a twenty-two-year span, we were unable to find any deal that did not feature at least one closure provision for defendants, and likewise found that nearly all settlements contained some provision that increased lead plaintiffs' lawyers' common-benefit fees. Bargaining for attorneys' fees with one's opponent is a stark departure from traditional contingent-fee principles, which are designed to tie lawyers' fees to their clients' outcome. Based on the evidence available to us, we found reason to be concerned that when repeat players influence the practices and norms that govern multidistrict proceedings-when they "play for rules," so to speak-the rules they develop may principally benefit them at the expense of one-shot plaintiffs.

INTRODUCTION $\ldots \ldots \ldots \ldots \ldots \ldots \ldots \ldots \ldots \ldots \ldots \ldots \ldots$

I. THE Rise of REPEAT Players in MultidistRict

LITIGATION

A. The Growth of Multidistrict Litigation and the Lack of Formal Rules .................. 1455

B. Why Repeat Players are so Likely in

Multidistrict Litigations .................. 1459

1. Lead Lawyer Selection Methods.......... 1460

2. Emphasis on Factors that Favor Repeat Players ......................... 1461

3. Settlement Pressure ................ 1463

C. Costs and Benefits of Repeat Play-Why This Matters ............................ 1465

II. EMPIRICALly ASSESSING REPEAT PlaY: THE SOCIAL NETWORK . . . . . . .................... 1469

A. Data Description and Sample Selection ..... 1470

B. The Network Methodology .............. 1472

C. Results ........................ 1475

1. The Social Network................... 1475

2. Centrality's Importance to Leadership Selection........................... 1484

III. EMPIRICALlY ASSESSING THE DEALS THOSE REPEAT Players DEsign ........................ 1488

A. Settlement Attorneys ................. 1495

B. Settlement Provisions and Lead Lawyers'

Fees ............................. 1496

1. Closure Provisions. .................... 1504 
2. Common-Benefit Fee Awards ........... 1509

3. Latecomer Reductions and Reversion

Clauses ......................... 1514

IV. ImPLICATIONS ....................... 1516

A. Repeat Players' Impact ............. 1518

B. Implications for Leverage, Ethics, and

Collusion ........................ 1521

C. Implications for Law Reform ........... 1526

APPENDIX .................................. 1532

\section{INTRODUCTION}

Time and again judges appoint the same plaintiffs' attorneys to lead large multidistrict litigations, then compensate them handsomely for doing so. But identifying repetitive play is merely the tip of the iceberg, for what lies beneath repeat plaintiff and defense attorneys' formal interactions has critical implications for the development of law and the fulfillment of fundamental procedural and tort goals such as fairness, efficiency, compensation, and deterrence. When repeat players interact over time, their past and present connections can impact norm development and entrenchment. Social architecture may thus affect how actors perceive ethically grey areas in structuring aggregate settlements, whether they privilege selfinterest over clients' interests, and how they approach regulatory ambiguities.

Because hard-and-fast formal rules are scarce when multidistrict litigation is not certified as a class action, transferee judges tend to seek guidance from predecessors, peers, and lawyers who have litigated other multidistrict proceedings. ${ }^{1}$ Even though multidistricting aims to avoid duplicative pretrial efforts, most cases settle. ${ }^{2}$ So, the small cadre of repeat players

1 For example, the Zyprexa litigation heavily influenced both the Guidant and the Vioxx litigation. E.g., In re Vioxx Prods. Liab. Litig., No. 1657, 650 F. Supp. 2d 549, 560 (E.D. La. Aug. 3, 2009); In re Vioxx Prods. Liab. Litig., No. 1657, 574 F. Supp. 2d 606, 611-12 (E.D. La. Aug. 27, 2008); In re Guidant Corp. Implantable Defibrillators Prods. Liab. Litig., No. 05-1708, 2008 WL 682174, at *17-18 (D. Minn. Mar. 7, 2008).

228 U.S.C. $§ 1407$ (a) (2012) (limiting multidistrict proceedings to pretrial litigation only); Lexecon, Inc. v. Milberg Weiss Bershad Hynes \& Lerach, 523 U.S. 26, 40 (1998). The Panel has remanded only 2.9\% of cases to their original districts. Since its creation in 1968, the Panel has centralized 462,501 civil actions for pretrial proceedings. By the end of 2013, a total of 13,432 actions had been remanded for trial, 398 had been reassigned within the transferee districts, 359,432 had been terminated in the transferee courts, and 89,123 were pending throughout the district courts. UNITED STATES COURTS, JUDICIAL PANEL ON MULTIDISTRICT LITIGATION-JUDICIAL BUSINESS 2013 (2013), http://www.uscourts.gov/statis- 
and the procedural norms they develop are integral to resolving the cases.

The prevalence of norms over formal, legal precedent affords repeat players a critical opportunity. As they act strategically to maximize gains over a series of cases, and play for "rules," the shorthand term for standardized practices that will tip the scales in their favor in future cases, those rules may well stick. When layered atop "bet-the-company" litigation, multimillion-dollar attorneys' fees, and significant media attention, the full picture for potential abuse and influence begins to emerge. Multidistrict cases like those against Volkswagen over its emission-defeat device ${ }^{3}$ and General Motors over its ignition-switch defect ${ }^{4}$ have increased in both prominence and quantity; they have risen from $16 \%$ of the federal courts' civil caseload in 2002 to $36 \%$ in $2014 .{ }^{5}$ Excluding social security and prisoner cases escalates that number to $45.6 \% .^{6}$ Consequently, through publicity, replication, and proportion, key players' influence and rules can impact the entire civil justice system. ${ }^{7}$

High stakes, rising filings, private settlements, and significant attorneys' fees-sometimes more than $\$ 350$ million $^{8}$ in common-benefit fees alone-have spurred heated debate. Multidistrict litigation's champions herald its quiet efficiency and ability to benefit claimants and attorneys through uniform decisions and resolutions. ${ }^{9}$ But critics suggest that it can lead to "lawless administration of aggregate claims" and "black holes." 10

tics-reports/criminal-justice-act-judicial-business-2013 [https://perma.cc/ XH8G-ZRDR].

3 In re Volkswagen “Clean Diesel” Mktg., No. 15-md-2672 (N.D. Cal. 2016).

4 In re GM LLC Ignition Switch Litig., No. 14-md-02543 (S.D.N.Y. 2014).

5 MDL Standards and Best Practices x, DUKE LAW CTR. FOR JUD. STUD. (2014).

6 Id. at $\mathrm{x}-\mathrm{xi}$.

728 U.S.C. $\S 1407$ (2012).

8 See Eldon E. Fallon, Common Benefit Fees in Multidistrict Litigation, 74 LA.

L. REV. 371, 385 (2014).

9 E.g., id. at 380; John G. Heyburn II, A View from the Panel: Part of the Solution, 82 TUL. L. REV. 2225, 2233 (2008).

10 E.g., In re United States Lines, Inc., 1998 WL 382023, at *7 (S.D.N.Y. 1998) (explaining appellants' description of the asbestos multidistrict litigation as "a black hole" and "the third level of Dante's inferno"); John G. Heyburn II \& Francis E. McGovern, Evaluating and Improving the MDL Process, 38 LITIG. 27, 31 (2012) ("The single most prominent complaint about multidistrict litigation arises from counsel's negative experiences in so-called black hole cases-those that seem not to move at an acceptable pace."); Linda Mullenix, Aggregate Litigation and the Death of Democratic Dispute Resolution, 107 Nw. L. REV. 511, 552 (2013) (noting that the use of "quasi-class action," a term used in some multidistrict proceed- 
The lead attorneys who run these litigations must act as fiduciaries to all plaintiffs, yet critics claim that those lawyers have engaged in self-enriching acts: by offering lead lawyers' " 'red-carpet treatment on fees' in return for favorable terms elsewhere," defendants can take advantage of lead attorneys' control over settlement negotiations to strike deals that benefit the leaders and the defendant, but not the claimants. ${ }^{11}$ Moreover, because transferee judges handpick lead attorneys and control their financial remuneration through fee transfers from non-lead attorneys, critics contend that "obedience is the prudent course for non-lead lawyers . . .."12 Critics likewise note that, as "veterans," leaders "have developed an arsenal of strategies to corral, convince, and coerce other lawyers to come together for purposes of organizing and settling cases en masse." 13 Yet, repeat players explain that it is only through their extensive experience and financial means that they can "go toe to toe" with big defense firms. ${ }^{14}$

Despite this burgeoning battle over multidistrict proceedings and the ramifications of repeat play, relatively little empirical research exists. This Article begins to fill that gap not just by collecting data or investigating the centrality of repeat plaintiff and defense attorneys, but also by analyzing the results they obtain on behalf of themselves and their clients. Part I launches this inquiry with a look into the circumstances behind multidistrict litigation's ascent and its absence of formal rules. When formal rules are scarce, socially constructed rules and norms impact legal outcomes on a broad scale. Accordingly, this Part theorizes the ways in which current practices, including judicial methods for selecting lead lawyers, create fertile conditions for repeat play and norm development. It likewise evaluates the costs and benefits of appointing repeat players, and thus rounds out the usual efficiency maxim that typically justifies centralizing cases. ${ }^{15}$

ings, "is a convenient, lazy fabrication to justify the lawless administration of aggregate claims.").

11 Charles Silver \& Geoffrey P. Miller, The Quasi-Class Action Method of Managing Multi-District Litigations: Problems and a Proposal, 63 VAND. L. REV. 107, 133 (2010).

12 Id. at 110.

13 Myriam Gilles, Tribal Rituals of the MDL, 5 J. TORT L. 173, 174 (2012).

14 Amanda Bronstad, 'Good Ol' Boys Club' in MDL, NAT'L L.J., Sept. 28, 2015; see also Perry Cooper, MDLs Led by Usual Suspects, and Not Everyone is Happy, BNA ClASS ACTION LITIG. RPT., June 24, 2016.

1528 U.S.C. $\S 1407$ (a) (2012) (noting that transfer must "promote the just and efficient conduct of such actions"). 
By focusing on the institutional players who routinelyand somewhat administratively-negotiate and settle similar claims, this Article then adds three missing ingredients to the empirical and theoretical literature on aggregate litigation. First, Part II introduces an affiliation network analysis (a scientific approach to understanding how agents in a complex system interact) ${ }^{16}$ to visualize the connections among plaintiffs' attorneys and between lead plaintiffs' and defense attorneys. To do this, we built an original dataset out of all the judicially selected lead lawyers in all product liability and sales practice proceedings pending on the multidistrict litigation docket as of May 2013-seventy-three total proceedings. The Judicial Panel on Multidistrict Litigation (the Panel) centralized those proceedings over a twenty-two-year span and collectively they include over 312,500 actions.

Using that data for the social-network analysis, Part II captures the interplay between lead plaintiff and defense attorneys. When many agents interact-judges, multiple attorneys, and defendants, for instance-game theory's traditional analytic focus on bilateral interactions can break down. ${ }^{17}$ Network analysis, however, provides us with a tool for mapping the complex connections between many people (lead attorneys) and events (multidistrict proceedings), allows us to identify critical actors and proceedings, and helps us to theorize more accurately about how multidistricting promotes efficiency and resolves cases. ${ }^{18}$ With the network intact, we can then hypothesize about what flows through it and what repeat players' connectedness might mean to the outcomes they generate. Central actors might, for example, wield their power to create

16 Daniel M. Katz \& Derek K. Stafford, Hustle and Flow: A Social Network Analysis of the American Federal Judiciary, 71 OHIO ST. L.J. 457, 467 (2010).

17 As John Miller and Scott Page point out:

When an agent interacts with only a few other agents, we can usually trace all of the potential actions and reactions. When an agent faces an infinity of other agents, we can average out . . . the behavior of the masses and again find ourselves back in a world that can easily be traced. It is in between these two extremes-when an agent interacts with a moderate number of others-that our traditional analytic tools break down.

John H. Miller \& ScotT E. PAGe, Complex AdAPtive Systems: An InTRoduction to COMPUTATIONAL MODELS OF SOCIAL LIFE 221 (2007).

18 See generally Nicholas A. Christakis \& JAMES H. Fowler, Connected: The SurPrising POWER OF OUR SOCIAL Networks AND HOW THEY SHAPE OUR Lives 9-10 (2009) (describing network attributes). 
and develop rules, influence settlement design, and shape ethical norms. ${ }^{19}$

Accordingly, Part III introduces the second ingredient missing from current scholarship: an empirical analysis of both the settlements repeat players design and the common-benefit fee practices used to compensate lead plaintiffs' lawyers. While the presence of tightly networked multidistrict-litigation attorneys is hardly surprising given our past findings, ${ }^{20}$ the influence these key players have on settlements has been largely ignored. Looking at the attorneys within the network, we confirmed that one of the top five most connected repeat players participated directly in each settled proceeding's leadership. We then analyzed the publicly available nonclass settlements that resulted within our dataset for provisions that may be more beneficial to counsel than to litigants. This brought to light the practices and norms that influential actors used to foster settlement and influence attorneys' fees outside of certified class actions.

All of the examined settlements featured at least one provision that encouraged closure and finality (which benefits the defendant), and nearly all settlements contained some provision that increased lead plaintiffs' lawyers' common-benefit fees. When plaintiffs' lawyers negotiate their fees with the defendant, it raises questions about self-dealing for it severs the traditional contingent-fee tie between attorneys and their clients and may compromise attorneys' loyalties. ${ }^{21}$ We thus found reason to be concerned that the rules and norms that repeat players collectively design may benefit them at the expense of one-shot plaintiffs.

To be sure, there is no viable means to demonstrate whether repeat play generates "better" or "worse" client outcomes, for few alternative settlement values are publicly available for comparison. And clauses that one might label as selfdealing or primarily benefitting counsel arise in the class context, too. ${ }^{22}$ But multidistrict litigation lacks Rule 23's struc-

19 See Charles Kadushin, Understanding Social NETworks: THEORIES, CONCEPTS, AND FINDINGS 202 (2013) (“[Social networks] are influenced by and responsive to social norms and institutions. Through repeated interactions, new norms and institutions are created.").

20 Elizabeth Chamblee Burch, Judging Multidistrict Litigation, 90 N.Y.U. L. REV. 71, 95-101 (2015); Margaret S. Williams, Emery G. Lee III \& Catherine R. Borden, Repeat Players in Federal Multidistrict Litigation, 5 J. TORT L. 141, 149-60 (Apr. 2014, backdated to 2012).

21 Silver \& Miller, supra note 11, at 134.

22 Howard M. Erichson, Aggregation as Disempowerment: Red Flags in Class Action Settlements, 92 NoTRE DAME L. REV. 859, 904 (2017). 
tural assurances of fairness-judicial settlement approval, objectors, and appeals. Setting aside bad faith and overt collusion, the fact that the same players appear in the vast majority of these proceedings and design remarkably similar settlements that benefit themselves raises new questions about adequate representation and the need for strong case management in multidistrict litigation.

Consequently, Part IV adds the third missing ingredient to the theoretical literature on aggregate litigation by exploring the impact well-connected repeat actors may have on case resolutions, ethical norms, and law reform. Take ethics, for example: the Model Rules of Professional Conduct were founded on an individual attorney-client relationship, and although rules like $1.8(\mathrm{~g})$ (the aggregate settlement rule) have evolved to address some concerns in mass representation, doctrinal confusion over the rule's application has opened it up to manipulation and social construction by the very parties it seeks to regulate. ${ }^{23}$ If the lines between ethical and unethical behavior blur and pushing boundaries benefits central players who possess the power and means to sanction others, that behavior may turn into the accepted norm. ${ }^{24}$ Accordingly, Part IV concludes by considering what effect a cohesive network of repeat actors may have on law reform efforts. Given agents' historical adaptability, regulatory designers may find more success with flexible measures that harness competitive forces already in play than top-down, external reforms.

23 E.g., Lynn A. Baker, Aggregate Settlements and Attorney Liability: The Evolving Landscape, 44 HOFSTRA L. REV. 291, 298-304 (2015).

24 Francesca Gina et al., Contagion and Differentiation in Unethical Behavior, 20 PSYCHOL. SCI. 393, 393-94, 398 (2009); see also Ernst Fehr \& Urs Fischbacher, Social Norms and Human Cooperation, 4 TRENDS IN COGNITIVE SCI. 185, 186-87 (2004) (discussing the relationship between social norms and punishment). Professor Charles Kadushin explains transmission through networks as follows:

[S]omething may be transmitted or diffused through (1) contact that involves some form of influence, persuasion, or coercion-for example, someone teaches me something or influences me to do something, to think a certain way, or provide me with a new tool; (2) contact that involves some kind of emulation-for example, my friend has an idea or tool that I think it would be useful to have; or (3) adoption or emulation without direct social contact-for example, I hear or read about something that I like.

KADUSHIN, supra note 19, at 135. 
I

The Rise of Repeat Players IN Multidistrict LITIGATION

Most people experience only the periphery of the legal system: requesting marriage licenses, paying traffic violations, executing and probating wills, and sometimes getting divorced. But, because of their profession or their size, certain people and corporations encounter the judicial system regularlythink Walmart or attorneys, for example. Of course, there is a wide margin between these two ends of the spectrum, and many people will have casual repeat encounters, falling somewhere in between "one-shotters" and more extensive "repeat players" as we use the term. ${ }^{25}$

Spurred by Marc Galanter's iconic work in the field, academics have long expected that routine repeat players who encounter the legal system time and again will have different goals than one-shotters. Regulars develop expertise, have a stable of go-to specialists, cultivate relationships with institutional incumbents like judges and their staff, and enjoy economies of scale with low start-up costs for any given case. ${ }^{26}$ Because they encounter the system and its inhabitants frequently, their reputation becomes important ${ }^{27}$ : attorneys might develop reputations as masterful trial lawyers or settlement artists, and corporations might decide to vigorously defend even meritorious cases to signal that they are not easy targets. Finally, repeat players tend to litigate with more in mind than just the stakes of a particular lawsuit. They may act strategically to maximize gains over a series of cases, and play for "rules," the short-hand term for standard practices and norms that will tip the scales in their favor in future cases. ${ }^{28}$

Much of the literature surrounding repeat players contemplates litigants as the repeat players-Walmart, Merck, or Johnson \& Johnson. ${ }^{29}$ And it is true that major corporate defendants are repeat actors in multidistrict litigation. But they are not the only ones. Many plaintiffs' and defense attor-

25 Marc Galanter, Why the "Haves" Come Out Ahead: Speculations on the Limits of Legal Change, in In LitigATION: Do THE "HAVES" STILl COME OUT AHEAD? 13, 14 (Herbert M. Kritzer \& Susan S. Silbey, eds. 2003).

26 Id.

27 Id.

28 Id.

29 E.g., Galanter, supra note 25, at 19, 22; see Ryan C. Black \& Christina L. Boyd, U.S. Supreme Court Agenda Setting and the Role of Litigant Status, 28 J. L. ECON. \& ORG. 286, 287-88 (2012). 
neys are repeat players, too. ${ }^{30}$ This leaves only one group as probable one-shotters: the plaintiffs themselves, and perhaps their individually retained attorney who must cede control to the judicially appointed lead lawyers-but typically not the lead lawyers themselves. To avoid having to coordinate with hundreds of attorneys, the judge appoints a small cadre of lawyers to run the lawsuit and make decisions on the group's behalf. Although plaintiffs' lead lawyers owe fiduciary obligations of loyalty to the plaintiffs, their judicial appointment insulates them from being fired or hired through conventional means. ${ }^{31}$

Corporate defendants, with a large cadre of sophisticated in-house attorneys, can easily and effectively monitor outside counsel. But multidistrict-litigation plaintiffs may be doubly disadvantaged: they are not only one-shotters, they also tend to be less knowledgeable about the law, which is, after all, why they hired an attorney. ${ }^{32}$ Yet, repeat plaintiffs' lawyers' financial interests might be intertwined with one another through formal joint-venture agreements that spell out funding coalitions, informal promises to distribute common-benefit work and leadership positions to allies, and settlement provisions that condition the deal on achieving a certain client participation rate. While lawyers compete with one another for leadership positions and clients, they may also play the long game to maximize their mutual financial gains. ${ }^{33}$ So, the concern is

30 Studies have shown, for example, that repeat players have been more successful in qui tam litigation, that attorneys who regularly appear before the same appellate court have higher win rates than their opponents, and that judges are more likely to vote against lawyers who lack experience before their court. David Freeman Engstrom, Harnessing the Private Attorney General: Evidence from Qui Tam Litigation, 112 Colum. L. REv. 1244, 1258 (2012); Susan Brodie Haire et al., Attorney Expertise, Litigant Success, and Judicial Decision Making in the U.S. Courts of Appeals, 33 LAW \& SOC'Y REV. 667, 678, 681 (1999).

31 PRINCIPLES OF THE LAW OF AGGREGATE LITIGATION $\S \S 1.04$ reporter's notes cmt. a, 1.05 illustrations 2, 4 (AM. LAW INST. 2010); Charles Silver, The Responsibilities of Lead Lawyers and Judges in Multidistrict Litigation, 79 FORDHAM L. REV. 1985, 1987-89 (2011).

32 See Robert W. Gordon, The Independence of Lawyers, 68 B.U. L. REV. 1, 30 (1988); Samuel Issacharoff \& Daniel R. Ortiz, Governing Through Intermediaries, 85 VA. L. REV. 1627, 1639 (1999); Russell Korobkin \& Chris Gutherie, Psychology, Economics, and Settlement: A New Look at the Role of the Lawyer, 76 TEX. L. REV. 77, 82 (1997).

33 E.g., Transcript of Proceedings at 41, In re Lithium Ion Batteries Antitrust Litig., No. 13-md-2420 (N.D. Cal. Apr. 16, 2013) [hereinafter Lithium Ion Batteries Transcript] ("Guido and I collectively have probably over a hundred years of experience . . . I've known Mr. Cotchett for decades, as well as the group from Lieff Cabraser. I've worked with them in virtually every case, so has everybody."). 
that repeat plaintiffs' lawyers may be more loyal to each other or even to defense attorneys than to their own clients. ${ }^{34}$

These issues do not occur in a vacuum; they take place against a rich backdrop of legal developments and socially and judicially constructed norms. Accordingly, this Part explores the legal context and leadership selection methodology, which sets the table for understanding how a small group of repeat players came to exert such a profound influence in aggregate litigation. It then considers those players' competitive advantages and the ways in which those advantages might serve or disserve plaintiffs.

A. The Growth of Multidistrict Litigation and the Lack of Formal Rules

Repeat players' influence derives in part from the steady use of multidistrict litigation to resolve mass harms as classcertification standards become more stringent. Corporations operate on an increasingly nationwide and worldwide scale, yet certifying a nationwide class action where state laws govern has become less likely due to a series of congressional and judicial decisions. Congress and the appellate courts have made certification more onerous by strengthening the commonality requirement, ${ }^{35}$ requiring plaintiffs to prove Rule 23 's prerequisites by a preponderance of the evidence, ${ }^{36}$ instructing judges to delve into a case's merits when the merits overlap

34 Galanter, supra note 25, at 24 ("The source of business generally counts for more than the client, especially where the client is unlikely to return or to send in other clients. The client is then expendable: he can be exploited to the full."). As plaintiff's attorney Francis Scarpulla noted in supporting the "consensus" group in the Lithium Ion Batteries litigation, "this group works collegially and cooperatively with every single person sitting at that defense table. I've known some of them for 45 years, as long as I [sic] been practicing. And I've probably been lead counsel in more cases than anybody in this courtroom . . . ." Lithium Ion Batteries Transcript, supra note 33, at 40. When the judge then asked the defendants' counsel about objections to the proposed plaintiffs' structure, Jim McGinnis responded, "I [sic] been practicing here for almost 34 years, have known all of the people on that side of the courtroom for most of those years, and I can tell you with the utmost confidence that I've never had a problem with any one of them." Id. at 44 .

35 Wal-Mart Stores, Inc. v. Dukes strengthened the commonality standard under Rule 23(a) and ensured that defendants could raise individual defenses, which could inhibit Rule 23(b)(3) certification. 564 U.S. 338, 363-67 (2011).

36 See Halliburton Co. v. Erica P. John Fund, Inc., 134 S. Ct. 2398, 2414 (2014); Amgen, Inc. v. Conn. Ret. Plans \& Trust Funds, 133 S. Ct. 1184, 1194-95 (2013) (internal citations excluded). 
with class-certification requirements, ${ }^{37}$ and complicating choice-of-law and manageability questions through federal jurisdiction. ${ }^{38}$ Thus, it is unsurprising that past researchers found an increasing number of personal-injury and productliability cases consolidated through multidistrict litigation, and a decreasing number of class-certification motions. ${ }^{39}$

Stricter certification requirements present challenges for the transferee judges who coordinate and manage multidistrict cases. While judges were often critiqued for their class-certification opinions, ${ }^{40}$ Rule 23 set forth clear judicial authority to appoint class counsel, ensure adequate representation, approve settlements, and award attorneys' fees. Plus, Rule 23(f) built in appellate jurisdiction, providing a clear path to error correction via interlocutory appeal. Time and again, appellate court judges overturned collusive deals that benefited the attorneys, but disserved class members. ${ }^{41}$

While plenary class certification has waned, claims of corporate wrongdoing have not. When those affected by corporate misconduct want to sue, plaintiffs' lawyers aggregate them through advertising and referrals, using the sheer number of people they represent to help defray litigation costs. Plaintiffs and their attorneys-many of whom who excelled in litigating class actions-are then transferred and coordinated through multidistrict litigation. ${ }^{42}$ This provides a forum with the same high-stakes, but without the overt judicial monitoring and error-correction built into Rule 23.

This leaves a lot of potential for both innovation and mischief. The lack of clear policing power has left judges scrambling to fill the void with class-action analogies and equitable

37 See Amgen, 133 S. Ct. at 1194-95; Wal-Mart Stores, Inc., 131 S. Ct. at 2551-52; In re Hydrogen Peroxide Antitrust Litig., 552 F.3d 305, 307, No. 07-1689 (3d Cir. Dec. 30, 2008).

38 Class Action Fairness Act of 2005 §§ 2(a), (b), Pub. L. No. 109-2, 119 Stat. 4, 5 (codified in scattered sections of 28 U.S.C.).

39 See Thomas E. Willging \& Emery G. Lee III, From Class Actions to Multidistrict Consolidations: Aggregate Mass Tort Litigation After Ortiz, 58 KAN. L. REV. 775, 777 (2010).

40 E.g., Pearson v. NBTY, Inc., 772 F.3d 778 (7th Cir. 2014).

41 E.g., id.; Eubank v. Pella Corp., 753 F.3d 718, 719 (7th Cir. 2014) (noting that the class action is "a worthwhile supplement to conventional litigation procedure" but that it is controversial "in part because it is frequently abused"); Reynolds v. Beneficial Nat'l Bank, 288 F.3d 277 (7th Cir. 2002). Scholarship is likewise rife with commentary on this concern. E.g., Erichson, supra note 22; Susan P. Koniak, Feasting While the Widows Weep: Georgene v. Amchem Products, Inc., 80 CORNELL L. REV. 1045 (1995); Susan P. Koniak \& George M. Cohen, Under Cloak of Settlement, 82 VA. L. REV. 1051 (1996).

4228 U.S.C. § 1407(a) (2012). 
powers. ${ }^{43}$ Without standardization, ad hoc practices develop, creating unpredictability and variation in key areas such as leadership appointments, compensating lead lawyers (in both practices and percentages), and endorsing or enforcing private settlements. ${ }^{44}$ To avoid the coordination problems inherent in communicating with many plaintiffs' attorneys, judges appoint leaders to shepherd the litigation and negotiate settlement. When those leaders perform work above and beyond what they would do for their own clients, they should be compensated. But there is no uniform theoretical basis or metric for doing so. ${ }^{45}$ Consequently, judges have tinkered with methodology and common-benefit percentages, sometimes cutting individual attorneys' fees along the way. ${ }^{46}$

This uncertainty over attorneys' fees prompts lawyers to experiment. Lead lawyers are searching for-and findingways to contract around judicial unpredictability via settlement. As we demonstrate, repeat attorneys with the most experience are more likely to be appointed to leadership positions, and those in leadership design settlements. ${ }^{47}$ But questions remain as to whether fee provisions in settlements benefit the litigants themselves. Without class certification, aggregate settlements are private deals that do not undergo Rule 23(e)'s vetting process to ensure that they are "fair, reasonable, and adequate." 48

43 E.g., In re Vioxx Prods. Liab. Litig., No. 1657, 574 F. Supp. 2d 606, 611 (E.D. La. Aug. 27, 2008); In re Guidant Corp. Implantable Defibrillators Prods. Liab. Litig., No. 05-1708, 2008 WL 682174, at*17 (D. Minn. Mar. 7, 2008); see also Linda S. Mullenix, Dubious Doctrines: The Quasi-Class Action, 80 CIN. L. REV. 389, 389-91 (2012) (criticizing the use of "quasi-class action").

44 E.g., In re Vioxx Prods. Liab. Litig., No. 1657, 650 F. Supp. 2d 549, 557 (E.D. La. Aug 3, 2009) (“[T]he parties have done more than simply ask the Court to approve a settlement agreement or move for a disbursement of funds. In fact, this Court is expressly authorized to be the Chief Administrator of the Settlement Agreement."); Howard M. Erichson, The Role of the Judge in Non-Class Settlements, 90 WASH. U. L. REV. 1015, 1024 (2013) ("Claims belong to claimants, not to the judge."); Jeremy T. Grabill, Judicial Review of Private Mass Tort Settlements, 42 Seton Hall L. Rev. 123, 127-29 (2012).

45 Burch, supra note 20, at 101-08.

46 E.g., In re Guidant, 2008 WL 682174 at*19 n.30; In re Zyprexa Prods. Liab. Litig., No. 04-01596, 424 F. Supp. 2d 488, 497 (E.D.N.Y. 2006) (awarding costs and lead lawyers' fees off the top of the general settlement fund, then awarding individual attorneys between 30 and 35\%). In Vioxx, however, the judge capped all lawyers' fees at $32 \%$ and then allocated $8 \%$ of that amount to lead lawyers. In re Vioxx Prods. Liab. Litig., No. 1657, 574 F. Supp. 2d 606, 607 (E.D. La. Aug. 27, 2008). This was later reduced.

47 Infra section II.C.2, Table 5.

48 FED. R. CIV. P. 23(e). 
Particular concerns arise in the aggregate settlement context because plaintiffs' claims and injuries can vary dramatically; multidistrict litigation requires only a common question of fact, not that common facts predominate as in a Rule 23(b)(3) class. ${ }^{49}$ If tried in plaintiffs' original fora, for a variety of reasons related to jury pool, injury severity, the lack of genetic predispositions, and even state laws, some plaintiffs would inevitably achieve awards much higher than those offered by an aggregate settlement. ${ }^{50}$ Thus, because their claims or circumstances present unique issues that deviate from the majority, some plaintiffs may experience suboptimal outcomes. ${ }^{51}$

It is here that nonclass cases can divege from class actions. In Rule 23(b)(3) class actions, dissatisfied class members-particularly those with idiosyncratic or high-value claims-can opt out. ${ }^{2}$ Competing attorneys exist to assist and even solicit them in this endeavor. When judges appoint class counsel and certify a class, only class counsel stands to gain from the attorneys' fees generated by the settlement. This incentivizes a host of lawyers who are otherwise ineligible for that fee award to investigate and cherry pick class members with individually marketable claims to opt out of the class regime. ${ }^{53}$

But the conditions in nonclass multidistrict litigation stifle the competitive check that exists in class actions in two ways. First, as the following section explains, the overwhelming message sent by transferee judges is that leadership appointments-and the lucrative fees that accompany them-are conditioned upon cooperation and team play. ${ }^{54}$ So, even though plaintiffs' attorneys are known to be an aggressive group, their rational and calculated response may be to publicly silence their discord and play the long game by climbing the leadership ranks. Second, there are more explicit reasons that even one-shot plaintiffs' attorneys do not buck. As we

49 Compare 28 U.S.C. § 1407(a) (2012) (requiring "civil actions involving one or more common questions of fact" as a predicate for multidistrict litigation), with FED. R. CIV. P. 23(b)(3) (requiring such common questions of fact to "predominate over any questions affecting only individual members" if it is the basis of a class action (emphasis added)).

50 The scholarly literature is rife with examples that we will not attempt to replicate here. The interested reader, however, might begin with these two sources: NEAL FEIGENSON, LEgAl BlaMe: How JURORS THINK AND TALK ABOUT ACCIDENTS (2000); Richard A. Nagareda, The Preexistence Principle and the Structure of the Class Action, 103 COLUM. L. REv. 149, 164 (2003).

51 See Nagareda, supra note 50, at 164.

52 FED. R. CIV. P. 23(c)(2)(v).

53 Nagareda, supra note 50, at 168-69.

54 E.g., Hon. Stanwood R. Duval, Jr., Considerations in Choosing Counsel for Multidistrict Litigation Cases and Mass Tort Cases, 74 LA. L. REV. 391, 393 (2014). 
demonstrate in this Article, settlements themselves can be designed to force them to capitulate by tying their own financial interests to defendants' ability to achieve closure. ${ }^{55}$

\section{B. Why Repeat Players are so Likely in Multidistrict Litigations}

To streamline and organize cases, transferee judges appoint a host of what we collectively term "lead lawyers": lead counsel, who head the litigation; steering and executive committees that make key decisions concerning litigation strategy and settlement; 56 liaison counsel, who disseminates information to other attorneys, calls meetings, and coordinates with counsel in related state (and sometimes bankruptcy) actions; and occasionally separate committee chairs such as discovery and trial committees. 57

Repeat players are especially likely to occupy these leadership positions for three reasons. First, by encouraging private ordering and consensus, judicial methods for selecting lead lawyers favor those who have litigated multidistrict litigations in the past. Previous players know one another, have worked together before, and are thus well positioned to take the helm. Second, the judges appointing attorneys for leadership roles stress attorneys' cooperative tendencies, which advantages lawyers with pre-existing relationships who have a track record of working well together. Finally, while all civil litigation tends to result in settlement over trial, the emphasis on settlement within multidistrict proceedings is especially pronounced. With less than three percent of cases ever returning to their court of origin and a persistent stigma of "remand-as-failure,"58 transferee judges have a strong desire to settle these cases. This suggests a need to select attorneys with experience settling complex matters over those who are relatively inexperienced. As discussed below, these three factors create fertile conditions for repeat play.

\section{Infra section III.B.1.}

56 Judges occasionally appoint a specific "negotiating committee," but lead counsel along with the steering or executive committee typically conduct settlement negotiations.

57 MANUAL FOR COMPLEX LITIGATION (FOURTH) § 10.221 (2004).

58 Eduardo C. Robreno, The Federal Asbestos Product Liability Multidistrict Litigation (MDL-875): Black Hole or New Paradigm?, 23 WIDENER L.J. 97, 144 (2013). See also Elizabeth Chamblee Burch, Remanding Multidistrict Litigation, 75 LA. L. REV. 399, 417-18 (2014) (explaining a host of factors that make settlement particularly attractive to transferee judges). 


\section{Lead Lawyer Selection Methods}

It is often impossible to determine precisely how judges select leaders. Attorney applications are rarely found on judicial dockets, judges tend not to be explicit about their actual methodology, and the attorneys' internal coordination efforts may ultimately dictate the slate. ${ }^{59}$ For example, judges may conduct an open application process, but may be given a choice between two competing consensus slates or may simply select the attorney with the most consensus support.

Still, judges typically use one of three methods: consensus methods, competitive selection, and a hybrid of those options. First, the consensus method relies on informal attorney networks to identify necessary leadership positions and select their own leaders; the judge then confirms the proposed slate. ${ }^{60}$ Second, the hybrid process allows temporary, "interim" lead counsel to apply, nominate liaison counsel and executive committee members, and appoint sub-committee members while simultaneously permitting an open application process. ${ }^{61}$ As one objector in the General Motors Ignition Switch litigation noted, however, this process "empowers [temporary lead counsel] to handpick the majority of the Executive Committee" and leaves only a few positions "open to a transparent application process." 62 Third, judges might implement competitive selection where the court invites submissions and

59 E.g., CARolyn A. Dubay, TREnds And PRoblems In the Appointment ANd CoMPENSATION OF COMMON BENEFIT COUNSEl IN COMPLEX MulTi-DisTRICT Litigation: AN EMPIRICAL STUDY OF TEN MEGA MDLs 32-33, Tbl. 3 (Oct. 2010) (unpublished manuscript, on file with authors) (identifying the procedures for appointing plaintiffs' leadership that varied substantially in levels of generality and observing "while the court may initially dictate a competition, consensus, or hybrid approach, ultimately the actions of the attorneys themselves will dictate the level of cooperation in the development of a leadership slate").

60 E.g., In re Neurontin Mktg. \& Sales Pract. \& Prods. Liab. Litig., No. 1629 (D. Mass. Dec. 14, 2004) (order granting motion to appoint counsel) (appointing plaintiffs' counsel's proposed slate); In re Genetically Modified Rice Litig., No. 1811 (E.D. Mo. Apr. 18, 2007) (appointing leadership counsel and observing that the group "most closely meets the 'private ordering' concept, because it has support of the larger number of plaintiffs and lawyers involved"). The first Manual for Complex Litigation recommended this approach, though it changed course by the second edition and advised judges to oversee the appointment process. Compare MANUAL FOR COMPLEX LITIGATION (FIRST) §§ 1.92, 4.53 (1982), with MANUAL FOR COMPLEX LITIGATION (SECOND) $§ 20.224$ (1985). Informal selection methods vary and may simply be based on a vote of attorneys invited to a particular meeting.

61 Letter to Judge Jesse M. Furman from Aaron S. Podhurst and Harley S. Tropin at 2, In re General Motors LLC Ignition Switch Litig., No. 14-md-02543 (S.D.N.Y. July 8, 2014).

62 Letter to Judge Jesse M. Furman from Steve W. Berman, Elizabeth J. Cabraser, and Mark P. Robinson, Jr. at 2, In re General Motors LLC Ignition Switch Litig., No. 14-md-02543 (S.D.N.Y. July 8, 2014). 
chooses among them. Judges might leave the vetting to special masters and law clerks, then treat the final selection as a confirmation hearing of sorts. ${ }^{63}$

In these latter two methods, judges sometimes permit competing attorneys to object to proposed nominees. Attorneys who work together frequently are likely to have superior information about one another's skills and temperament. Thus, allowing objections can impart valuable vetting information to judges and special masters. But repeat players may reveal that information only if solicited privately. When judges require attorneys to serve their objections on all counsel, ${ }^{64}$ or solicit objections in open court, 65 they are unlikely to receive candid feedback. The conditions are ripe for conformity and information cascades: the relevant plaintiffs' bar is small, lead lawyers can influence and sometimes directly control one another's attorneys' fees, lawyers must often rely on each other to form funding coalitions, and, as explained below, being dubbed "uncooperative" may render defectors ineligible for future leadership roles. ${ }^{66}$

\section{Emphasis on Factors that Favor Repeat Players}

When judges consider applicants for leadership positions, they focus on experience, cooperative tendencies, and an ability to finance the litigation ${ }^{67}$-factors that favor repeat players.

63 E.g., Special Master's Rule 23 Report Recommending Interim Plaintiff Leadership Counsel, In re Blue Cross Blue Shield Antitrust Litig., No. 2:13-cv20000-RDP (N.D. Ala. Apr. 10, 2013).

64 E.g., In re Oil Spill by the Oil Rig "Deepwater Horizon" in the Gulf of Mexico, on Apr. 20, 2010, No. 10-2179, slip op. at 14 (E.D. La. Aug. 10, 2010) (pretrial order no. 1) (setting initial conference).

65 E.g., Lithium Ion Batteries Transcript, supra note 33, at 1-28.

66 See Infra subpart IV.B; see generally CASS R. SUNSTEIN, WHY SOCIETIES NEED DISSENT 28-29 (2003) (discussing the role of group identification and conformity); ROBERT C. ELLICKSON, ORDER WITHOUT LAW 170-74 (discussing the role of sanctions for objectors/defectors in close-knit groups who aim to maximize their own welfare). But see Lithium Ion Batteries Transcript, supra note 33, at 49 (claiming that if selected, the consensus group would not exclude objectors from receiving work).

67 Dubay, supra note 59, at 39-40, Tbl. 6 ("[T]he courts with specific orders as to qualifications focused on experience in MDLs or complex litigation and the ability and resources to commit to the leadership responsibilities.”). E.g., In re Oil Spill by the Oil Rig "Deepwater Horizon" in the Gulf of Mexico, on Apr. 20, 2010, No. 10-2179, slip op. at 13-14 (E.D. La. Aug. 10, 2010) (pretrial order no. 1) (setting initial conference); In re Boston Sci. Corp., Pelvic Repair Sys. Prods. Liab. Litig., No. 2326, at 9 (S.D. W. Va. Feb. 29, 2012) (pretrial order no. 1) ("The main criteria for PSC membership will be: (a) willingness and availability to commit to a time-consuming project; (b) ability to work cooperatively with others; and (c) professional experience in this type of litigation."); Duval, supra note 54, at 393 (listing "team players," "expertise," and "financial considerations" as factors in selecting leadership). 
To gauge these criteria, judges often request short four to five page submissions, and call other judges to ask about disruptive attorneys. ${ }^{68}$ Even attorneys' submissions sometimes suggest a litany of judges who can vouch for the applicant's reputation and "proven ability to work well with others."69 When writing about selection criteria, the judge who presided over the Hurricane Katrina litigation listed "team players" as "the primary factor in choosing lead counsel, liaison counsel, or even membership on a steering committee."70

In the abstract, experience and cooperation seem like positive attributes. And experience in building the relevant infrastructure to litigate claims is critical. But in reality, emphasizing cooperation can lead to three negative effects that may dampen the advantage that experience confers. First, it may foster a need for attorneys to curry favor with one another to secure lucrative positions in future leadership hierarchies. Second, it deters dissent by implicitly labeling it as something that should not be rewarded. Yet, dissent can be particularly important during settlement.

The lack of dissent prompts a third concern over adequate representation. ${ }^{71}$ Because multidistrict litigation's authorizing statute requires that cases share only a single common question of fact, ${ }^{72}$ claimants' best interests are unlikely to be uni-

68 E.g., In re Oil Spill by the Oil Rig "Deepwater Horizon" in the Gulf of Mexico, on Apr. 20, 2010, No. 10-2179, slip op. at 14 (E.D. La. 2010) (pretrial order no. 1) (setting initial conference); Transcript of Proceedings on November 16, 2012 at 16-17, In re Biomet M2a-Magnum Hip Implant Prods. Liab. Litig., No. 12-md2391 (N.D. Ind. Nov. 16, 2012) ("I know most of the judges who have your MDLs, and so I emailed them this week, gave the list of names that had been submitted, and said, 'Tell me anybody who [sic] I should not appoint.'”).

69 Plaintiffs' Proposed Counsel Organizational Structure at 12, 25-26, In re Biomet M2a-Magnum Hip Implant Prods. Liab. Litig., No. 12-md-2391 (N.D. Ind. Nov. 16, 2012) (leadership applications of Mark Lanier and Douglass Kreis); see also Lithium Ion Batteries Transcript, supra note 33, at 25-26 (“[O]ur firm was specifically commended by both the special master and [the court] for the role we played. And I submitted the order of special master Martin Quinn where he said that we did a superb job in many important aspects of the case.").

70 Duval, supra note 54, at 393.

71 See Amchem Prods., Inc. v. Windsor, 521 U.S. 591, 625-26 (1997); Hansberry v. Lee, 311 U.S. 32, 45 (1940); Burch, supra note 20, at 87-91 (arguing that adequate representation concerns extend to multidistrict litigation); Elizabeth Chamblee Burch, Monopolies in Multidistrict Litigation, 70 VAND. L. REV. 132-33, 144 (2017) (contending that Due Process protections apply to nonclass aggregation). Monopolies in Multidistict Litigation is a solo-authored companion piece that offers normative insights based on this Article's empirical and network analysis.

7228 U.S.C. $\S 1407$ (2012). See Martin H. Redish \& Julie M. Karaba, One Size Doesn't Fit All: Multidistrict Litigation, Due Process, and the Dangers of Procedural Collectivism, 95 B.U. L. REV. 109, 141 (2015) ("The dangers of MDL from the 
form. And the claimants most likely to be disserved by nonclass multidistrict litigation-and thus most in need of dissent on their behalf-are those with unique or high-value claims. As Professor Richard Nagareda elaborated in the class context, "[M]embers with high-value claims are the ones most at risk from the sale of claims en masse by class counsel as monopolist. The greater the variance in claim value, the more fervent the effort at variance reduction through the embrace of a class settlement that dampens the prospect for variance at the high end of the damage scale . . ."73 The same logic holds true when multidistrict proceedings are resolved through mass-though not class-settlement, as is the case for most product liability and sales practice proceedings. ${ }^{74}$ But incentives to dissent are weaker.

Unlike class actions, where the defendant has reason to raise conflicting interests when battling class certification, the controlling stakeholders in nonclass multidistrict litigationplaintiffs' lead lawyers, defendants, and their attorneys-have little economic motive to raise conflicts. Lead lawyers have two income sources: contingent fees from their own clients and court ordered "taxes" from plaintiffs (and their individual counsel) who benefit from leaders' efforts. Attorneys profit from representing as many people as possible-not from recognizing divisive interests. And defendants' closure hinges not on the preclusive effect of a class-wide settlement that demands adequate representation, but on convincing claimants to accept a settlement offer. Consequently, judicial pressure toward cooperation and consensus may erode dissent and the adequate representation that follows from it.

\section{Settlement Pressure}

As is the case nationwide, in multidistrict proceedings there are far more claims than an individual judge can try in full. ${ }^{75}$ As the proceedings in our database illustrate, this creates systemic pressure to settle that is exacerbated by the continued control that key stakeholders can exert through centralization and the transferee judges' reluctance to remand

perspective of the paternalism model are exacerbated by the extremely loose connection required among the claims.").

73 Nagareda, supra note 50, at 167 (footnote omitted). This logic holds in multidistrict litigation as well.

74 See infra Figure 1 (providing an overview of how courts resolved the products-liability and sales-practices multidistrict proceedings within our dataset).

75 Galanter, supra note 25, at 25. 
cases. ${ }^{76}$ As of May 11, 2016, of the seventy-three multidistrict product-liability and sales-practice proceedings that were pending as of May 2013, parties settled thirty-one proceedings through holistic aggregate or inventory settlements, twenty through class-action settlements, one through individual settlements, and one through bankruptcy. ${ }^{77}$ Defendants successfully used Daubert motions, summary judgment, and arbitration to resolve ten proceedings, and the remaining ten proceedings are still ongoing.

Figure 1: RESOlutions WITHIN THE DATASET OF MULTIDISTRICT PRODUCTS-LiabILITY AND SALES-PRACTICE PROCEEDINGS

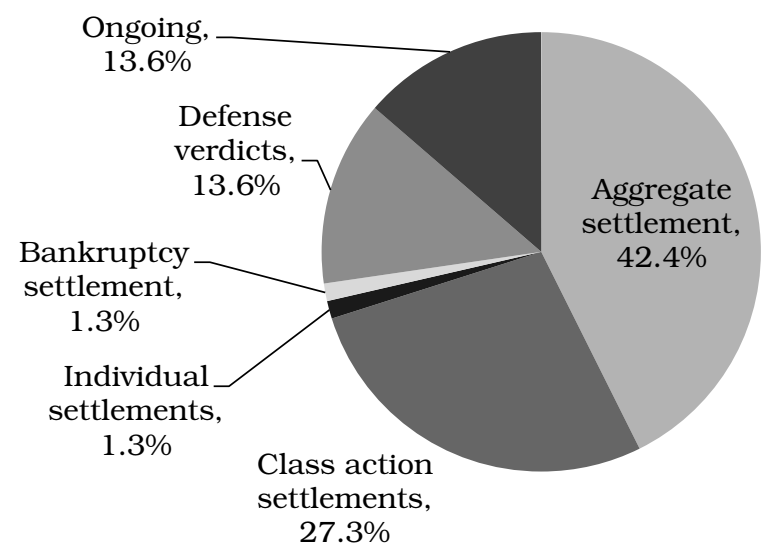

Settlement shields practices and emerging "rules" from appellate review, making change and disruption less likely. ${ }^{78}$ Settlement likewise allows repeat players to expand their power beyond the federal court's jurisdiction. As transferee judges recognize their limited authority to command parallel litigation in state courts-at least beyond informal coordination-repeat players may seize the opportunity to benefit from fees in competing state cases through settlement design. ${ }^{79}$ As lead lawyers who liaise with state counsel and bargain with the defendant, they hold substantial power to negotiate master set-

76 See Burch, supra note 58, at 410-20; Redish \& Karaba, supra note 72, at 128-29.

77 Table Al in the appendix includes the proceedings' consolidation dates.

78 Galanter, supra note 25, at 26.

79 E.g., In re Genetically Modified Rice Litig., 764 F.3d 864, 874 (8th Cir. 2014). The judge has now certified a class composed of those lead lawyers, other law firms, and clients who paid for common-benefit services and expenses that is suing objectors for unjust enrichment and quantum-meruit claims. Downing v. Goldman Phipps PLLC, 2015 WL 4255342 (E.D. Mo. July 14, 2015). 
tlement agreements that require settling plaintiffs to consent to common-benefit fees. 80

Table 1 below summarizes the ways in which repeat players gain the upper hand in multidistrict litigation, highlights opportunities for norms to enter the picture, and notes judicial deference to emerging practices and claims handling.

TABle 1: Repeat Player AdVANTAGES

\begin{tabular}{|c|c|c|c|c|}
\hline & Goals & $\begin{array}{c}\text { Institutional and rule } \\
\text { entrenchment }\end{array}$ & $\begin{array}{c}\text { Extra-legal norm } \\
\text { entrenchment and } \\
\text { enforcement }\end{array}$ & $\begin{array}{r}\text { Additional } \\
\text { advantages }\end{array}$ \\
\hline $\begin{array}{l}\text { Defendants } \\
\text { and their } \\
\text { attorneys }\end{array}$ & $\begin{array}{l}\text { Avoid liability } \\
\text { Achieve cost- } \\
\text { effective } \\
\text { finality across } \\
\text { state and } \\
\text { federal courts }\end{array}$ & $\begin{array}{l}\text { Legislation and } \\
\text { centralization pools } \\
\text { cases and creates a } \\
\text { single bargaining unit } \\
\text { (§ 1407, CAFA) } \\
\text { Transferee judges' } \\
\text { reluctance to remand } \\
\text { Judges cannot fully } \\
\text { litigate every case } \\
\text { Little appellate review }\end{array}$ & $\begin{array}{l}\text { Ability to negotiate for } \\
\text { plaintiffs' attorneys' fees } \\
\text { Settlement offer } \\
\text { withdrawal as a sanction } \\
\text { on uncooperative } \\
\text { plaintiffs' attorneys } \\
\text { (withdrawal provisions } \\
\text { in settlement) }\end{array}$ & $\begin{array}{l}\text { Specialized } \\
\text { expertise }\end{array}$ \\
\hline $\begin{array}{l}\text { Plaintiffs' } \\
\text { lead lawyers }\end{array}$ & $\begin{array}{l}\text { Bargaining } \\
\text { credibility } \\
\text { Attorneys' fees } \\
\text { (from clients } \\
\text { and } \\
\text { leadership } \\
\text { roles) } \\
\text { Future } \\
\text { leadership } \\
\text { appointments } \\
\text { Client } \\
\text { recoveries }\end{array}$ & $\begin{array}{l}\text { Judges' leadership } \\
\text { selection criteria favor } \\
\text { repeat players } \\
\text { Centralization creates } \\
\text { leadership structure } \\
\text { (§ } 1407(a) \text { ) } \\
\text { Judges cannot fully } \\
\text { litigate each case } \\
\text { Little appellate review }\end{array}$ & $\begin{array}{l}\text { Cooperative norms } \\
\text { Reciprocity concerns } \\
\text { Negotiating and work- } \\
\text { distribution authority } \\
\text { for group } \\
\text { Ability to socially and } \\
\text { financially sanction non- } \\
\text { cooperative plaintiffs' } \\
\text { lawyers }\end{array}$ & \begin{tabular}{|l} 
Specialized \\
expertise and \\
experience \\
Some judicial \\
deference to \\
claims \\
handling \\
Ability to \\
finance the \\
litigation \\
Judicial and \\
peer \\
references \\
\end{tabular} \\
\hline
\end{tabular}

\section{Costs and Benefits of Repeat Play-Why This Matters}

As Table 1 illustrates, multidistrict litigations are ripe not only for repeat players to influence, create, and change the standard practices-"rules," for short-that occur within them, but also to entrench those rules. First, appellate oversight is rare. Cases often conclude through private settlements that are not appealable; 81 interim rulings, such as those appointing lead lawyers or creating common-benefit funds, are not dispositive and are reviewable only through an extraordinary writ of mandamus or subsequent dismissal;82 and, in the unlikely event of appellate review, courts use the deferential abuse-of-

\footnotetext{
80 See infra section III.B.2.
}

81 Some judges have expressly waived parties' ability to appeal through their common-benefit fund participation agreement. E.g., In re C.R. Bard, Inc. Pelvic Repair Sys. Prods. Liab. Litig., No. 2187 (S.D. W. Va. Oct. 4, 2012) (Pretrial Order No. 54, at 5-6).

82 See Cunningham v. Hamilton Cty., 527 U.S. 198, 207 (1999); Firestone Tire \& Rubber Co. v. Risjord, 449 U.S. 368, 376-78 (1981); Redish \& Karaba, supra note 72 , at 142 . 
discretion standard.83 Second, because formal, hard-and-fast rules are scarce, transferee judges tend to look to their predecessors and peers for guidance. ${ }^{84}$ Without much external scrutiny, past practices may become best practices and experienced repeat players could cite, replicate, and improve upon procedures that benefitted them while discarding those that did not.

Repeat players can shape leadership appointments in at least three ways. First, the consensus-selection method (and even methods where the judge formally selects but defers to private ordering) allows repeat players to proffer a preordained leadership slate. ${ }^{85}$ Second, even if the transferee judge employs a competitive-selection process for key positions like lead and liaison counsel as well as the steering committee, chosen leaders can then select attorneys to perform the work or serve on sub-committees, like a discovery committee. Third, in openselection or hybrid-selection methods, repeat players may vouch for one another's cooperative abilities, providing a chorus of support-either in writing or in open court-for the unofficial consensus nominees. ${ }^{86}$

Once appointed, leaders can likewise work to maximize their common-benefit fees. Because there is no firm doctrinal ground to guide judges in awarding these fees, 87 ample opportunities exist for lead lawyers to influence their compensation. First, judges often implement leaders' proposed common-benefit orders, and defer to leaders' requests to raise fees during the proceeding. 88 Second, in some multidistrict proceedings, judges may create a fee-allocation committee comprised of the

83 E.g., In re Vioxx Prods. Liab. Litig., No. 09-30446, 388 Fed. Appx. 391 (5th Cir. July 16, 2010) (using the abuse-of-discretion standard in reviewing the allegation that the judge should have recused himself based on his dual roles as judge and Chief Administrator of the Master Settlement Agreement).

84 For example, the opinions in Zyprexa heavily influenced the oversight of Guidant and Vioxx. E.g., In re Vioxx Prods. Liab. Litig., No. 1657, 650 F. Supp. 2d 549, 560 (E.D. La. Aug. 3, 2009); In re Vioxx Prods. Liab. Litig., No. 1657, 574 F. Supp. 2d 606, 611-12 (E.D. La. Aug. 27, 2008); In re Guidant Corp. Implantable Defibrillators Prods. Liab. Litig., No. 05-1708, 2008 WL 682174, at*17-18 (D. Minn. Mar. 7, 2008).

85 For example, in the Lithium Ion Batteries Antitrust Litigation, when plaintiffs' attorneys could not reach a complete consensus as to who would represent the indirect purchasers before the court's hearing, Dan Becnel noted, "I tried towhen we came down here to-to have three [lead counsel], make a deal, and-and Mr. Berman decided not to. So the bulk of us think Mr. Cotchett and the Cabraser firm are excellent." Lithium Ion Batteries Transcript, supra note 33, at 51.

86 E.g., id. at 59 ("And we are also supporting the Cotchett, Lieff motion, but we are glad to work with all three firms.").

87 See Burch, supra note 20, at 102-09.

88 See Dubay, supra note 59, at 22-23, 54-55; infra notes 239-242 and accompanying text. 
principal lead lawyers. ${ }^{89}$ This means that at any given time, lawyers could pressure other attorneys through their influence over fees in concurrent multidistrict proceedings. Third, repeat players may understand-and perpetuate-norms about which kind of work is most beneficial (and thus most deserving of enhanced compensation), perform that work themselves, and delegate less profitable tasks to others. ${ }^{90}$ Finally, as the settlement designers, lead lawyers could insert fee provisions into settlements, negotiate their fees directly with the defendant, and contract around judicial fee orders to tax settling state-court plaintiffs via master settlement agreements. ${ }^{91}$

To be sure, repeat play can generate positive effects, too. First, repeat players capitalize on economies of scale and their acquired knowledge is imperative. It takes expertise to comprehend the science behind injuries, understand the risks of various litigation strategies, build the infrastructure that accompanies a multidistrict proceeding, and manage litigation effectively. ${ }^{92}$

Second, repeat actors are intimately familiar with the myriad layers of administrative service providers who work behind the scenes from claim initiation to resolution, but may renege on their price structuring and deliverables. These providers range from client-intake call centers and client-referral services that promise to deliver client leads through advertising ${ }^{93}$ to

89 E.g., In re Yasmin and Yaz (Drospirenone) Mktg., Sales Practices \& Prods. Liab. Litig., No. 09-md-2100 (S.D. Ill. Mar. 18, 2015) (case management order no. 71) (creating a fee committee with five of eight members appointed by co-lead and liaison counsel).

90 E.g., Special Master's Report and Recommendation Regarding the Allocation and Distribution of Common Benefit Fees and Expenses at 13-14, In re NuvaRing Prods. Liab. Litig., No. 08-md-1964 (E.D. Mo. Dec. 16, 2014) (discussing the novelty and difficulty of the questions addressed by counsel and the skill requisite to perform the legal work as factors used to distribute fees). Kristine Kraft, Paul Rheingold, Steven Blau, and Roger Denton were appointed as lead counsel in NuvaRing. In re NuvaRing Prods. Liab. Litig., No. 08-md-1964 (E.D. Mo. Oct. 8, 2008) (order appointing lead lawyers). Combined, their three firms netted \$7.4 million of a total $\$ 10,123,395.00$ of fees awarded to ten total firms. Kraft and Denton's firm, Schlicter, Bogard \& Denton LLP received \$6.9 million of the $\mathbf{\$ 7 . 4}$ million. Exhibit 1 to Special Master's Report and Recommendation Regarding the Allocation and Distribution of Common Benefit Fees and Expenses at 13-14, In re NuvaRing Prods. Liab. Litig., No. 08-md-1964 (E.D. Mo. Dec. 16, 2014).

91 See infra subsection III.C.2.b.

92 Amanda Bronstad, 'Good Ol' Boys Club' in MDL, NAT'L L.J., Sept. 28, 2015 (quoting Richard Arsenault as saying, "A lot of deference should be given to experienced plaintiffs' counsel who have been in these wars and understand what kinds of teams they need to put together.").

93 E.g., GACOVINO LAKE [https://perma.cc/Z58W-VDE7];THE SENTINEL GROUP [https://perma.cc/GZB9-8Y8R]; RELION-GROUP [https://perma.cc/2E5T-397E]. 
marketing firms, ${ }^{94}$ document repositories, and claims administrators. ${ }^{95}$ In this way, multidistrict litigation is merely one facet of a broad network of stakeholders. ${ }^{96}$ Because there is little direct judicial oversight and regulation, particularly with regard to pricing document databases and claims administration, repeat play incentivizes providers to follow through on their commitments. Yet, this also creates opportunities for service providers to conspire with repeat players in ways that disserve plaintiffs.

Third, when repeat players get involved in a multidistrict litigation, it signals to other plaintiffs' lawyers and defendants that it's a high-stakes case. Certain firms are known to intensively vet cases with experts long before filing a complaint. Consequently, their reputation may encourage others to advertise and recruit clients, and prompt cases to settle more quickly than they otherwise might. Those settlement values may likewise reflect repeat players' knowledge about previous awards, which helps prevent defendants from using information asymmetries to their advantage. ${ }^{97}$

Finally, attorneys who have worked together closely in the past will know more about one another's work habits and expertise than the judge. As lawyers form leadership groups for a particular case, they might design their team to maximize one another's strengths. Moreover, because they work together frequently, repeat players can use social and financial sanctions to enforce norms and promote efficiency beyond simplistic efficiencies such as avoiding duplicative discovery and pre-trial motions. For example, it makes sense to ostracize disorganized attorneys with poor work product, those who are inefficient time-managers with inflated billable hours, and those who cannot complete assignments on time. Yet, reciprocal relationships might likewise mean that attorneys who would otherwise

94 E.g., CONSUMER ATTORNEY MARKETING GROUP [https://perma.cc/3LWKEK3M]; ILAWYERMARKETING [https://perma.cc/23YG-EVSB].

95 E.g., BROWNGREER [https://perma.cc/2CM5-2RLR]; Garretson, [https:// perma.cc/7GB9-VT6X]; Providio [https://perma.cc/M7GH-EATM]; RUST CONSULTING [https://perma.cc/Q8X5-4YMK].

96 See KADUSHIN, supra note 19, at 123-24 (noting that any set of nodes in network theory inevitably has real-life ties to other nodes that affect the network and the flow).

97 See Samuel Issacharoff \& John Fabian Witt, The Inevitability of Aggregate Settlement: An Institutional Account of American Tort Law, 57 VAND. L. REV. 1571, 1581-84, 1599-1600 (2004). 
be excluded for their various failings may nevertheless remain if lead or liaison counsel is indebted to them. 98

Given the degree of specialization and success required to fund firms' capital contributions in multidistrict litigation, this segment of the plaintiffs' bar is relatively small; reciprocal relationships form, and an attorney's reputation matters immensely. Playing the long game may not only allow repeat players to play for rules and reap the advantages those rules provide, but also empower those attorneys to influence and control group dynamics in ways that could impinge on client representation. ${ }^{99}$

Accordingly, whether the positive gains outweigh the potential negatives remains to be seen. ${ }^{100}$ Because repeat players have so much control with so few external safeguards and so little incentive to draw attention to deals that may not favor litigants over lawyers, there is a pressing need to examine both who repeat players are and the deals they design. Consequently, we turn now to those tasks using a dataset of repeat players in products-liability and sales-practices multidistrict litigation.

II

EMPIRICALLY ASSESSING REPEAT PLAY: THE SOCIAL NETWORK

Before we can analyze repeat players' impact, we must first determine whether and the degree to which they exist. Our previous work suggests that they do, ${ }^{101}$ but the data in this Article offer some benefits not provided by past work, which focused solely on plaintiffs' attorneys. We not only include plaintiffs' lawyers in our network, but incorporate defense attorneys and law firms as well, which provides a more complete picture of repeat play. Additionally, this Article does not just focus on who appears most often; it also examines their leader-

98 Scholars have consistently claimed that social factors, and not necessarily expertise, may influence organizations and institutions. E.g., Katz \& Stafford, supra note 16 , at 459 .

99 Inadequate representation can raise due process concerns. See Amchem Prods., Inc. v. Windsor, 521 U.S. 591, 625-26 (1997); Hansberry v. Lee, 311 U.S. 32, 45 (1940); Burch, supra note 20, at 87-91 (arguing that adequate representation concerns extend to multidistrict litigation); Burch, supra note 71, at 132-33, 144 (contending that Due Process protections apply to nonclass aggregation); Redish \& Karaba, supra note 72, at 151.

100 For an important perspective that efficiency should not outweigh Constitutional due process protections such as adequate representation, see Redish \& Karaba, supra note 72 , at $146-51$.

101 Burch, supra note 20, at 95-101; Williams et al., supra note 20, at 141. 
ship positions, which helps gauge the participation and influence levels that allow attorneys to control litigation and shape settlements. After establishing who is in the repeat-player network, we then analyze the publicly available nonclass settlements that these leaders create.

\section{A. Data Description and Sample Selection}

To achieve some sense of how prevalent repeat players (individual attorneys and law firms) are in multidistrict litigation, we built an original dataset that includes all judicially appointed lead plaintiff and defense lawyers in all products-liability and sales-practices multidistrict litigations pending as of May 14, 2013. This date allows us to examine an array of resulting settlements. ${ }^{102}$ A list of these 73 proceedings appears in Appendix A1; collectively the proceedings include approximately 312,555 actions.

If repeat players exist, these proceedings should provide a representative sample for several reasons. First, products liability and sales practices constitute well over one-third of all multidistrict proceedings-the largest segment by far. ${ }^{103}$ And looking beyond the simple count of multidistrict proceedings to the actual number of actions contained in each shows that products liability comprise up to $92 \%$ of all those pending actions. ${ }^{104}$ Second, examining pending cases on a certain date includes data from cases centralized over a twenty-two-year

102 We identified the relevant proceedings using the Panel's list of pending multidistrict litigations as of May 14, 2013. Because the Deepwater Horizon Oil Spill proceeding dealt with issues similar to products liability, such as physical harm and economic loss, we also included it. One case mentioned on that May 14, 2013 list was excluded because the orders were not electronically available (In re Methyl Tertiary Butyl Ether ("MTBE") Prods. Liab. Litig., which began in 2000). Only interim counsel appointments were available in In re Plavix Marketing, Sales Practices and Products Liability Litigation and In re Toyota Motor Corp. Hybrid Brake Marketing, Sales Practices, and Products Liability Litigation. Finally, we included five separate multidistrict litigations over pelvic-repair systems transferred to the Southern District of West Virginia. The transferee judge named the same 62 attorneys as lead lawyers in four of those five cases. Coding those four litigations as one would reduce the percentage of repeat play: repeat attorneys would hold 54.9\% of all lead-lawyer positions and repeat law firms would occupy $73.2 \%$ of the available positions. Because the Panel could have created one large multidistrict case, but chose not to do so, we treat these five proceedings separately.

103 Calendar Year Statistics of the United States Judicial Panel on MultidisTRICT LITIGATION 12 (2012) (showing 34 sales practices multidistrict litigations and 72 products liability litigations out of 291 total multidistrict litigations).

104 Samuel Issacharoff, Snapshot of MDL Caseload Statistics 3, DUKE LAW CTR. FOR JUDICIAL STUDIES (2015), https://law.duke.edu/judicialstudies/conferences/ october2015/materials/ [https://perma.cc/8ZMQ-RYUR]. 
span. ${ }^{105}$ Third, to the extent possible, we included data from all orders appointing lead lawyers (plaintiffs' steering committees, plaintiffs' liaison committees, discovery committees, trial committees, defendant's lead counsel, etc.), not just lead counsel. While lead counsel has the most power in any proceeding, the additional steering or executive committee members follow them closely. Once lead lawyers negotiate a master settlement, liaison counsel also plays a vital role in marketing the deal to individual lawyers both inside and outside the multidistrict proceeding-including those attorneys litigating solely in state courts. When taken as a whole, this information should give an accurate sense of the scale of repeat play.

Our data confirmed that repeat players populate most multidistrict leadership positions. On the plaintiffs' side, repeat players (attorneys who held more than one leadership position within our dataset) held 767 out of 1,221 available leadership roles, or $62.8 \%$. Fifty attorneys were named as lead lawyers in five or more multidistrict litigations and those 50 attorneys occupied $30 \%$ of all plaintiff-side leadership positions. ${ }^{106}$ A full list of those attorneys appears in Appendix A2, and a partial list of the top 25 high-level players appears subsequently in Table 3. Repeat play among plaintiffs' law firms was even more evident. Again, even though only $40.7 \%$ of law firms were repeat players (i.e., had more than one lawyer from that firm appointed to a leadership position within the dataset), lawyers from those 70 firms occupied $78 \%$ of all available leadership positions. ${ }^{107}$ Seventy law firms had attorneys who were named to five or more leadership roles, and attorneys from those firms were appointed to well over half of all lead-lawyer positions. Put starkly, $16 \%$ of the involved law firms held nearly $54 \%$ of all leadership positions. Appendix A3 contains a list of plaintiffs'side repeat-player law firms with the greatest number of appearances.

On the defense side, repeat players held 73 of 414 leadership positions, or $17.6 \%$. Of course, defense lawyers are rarely

105 As noted in footnote 102, one older case was excluded because the orders were not available electronically, but In re Asbestos Products Liability Litigation, which began in 1991, is included.

106 This statistic does not count lawyers who occupied multiple leadership positions within the same multidistrict litigation.

107 Two judges named entire law firms as lead or liaison counsel. Where possible, only the attorneys from the named law firm who were "to be notified by the court" on PACER were included in the data. The number of available leadership positions from the law firm perspective was 1,222 , and lawyers from firms named more than once occupied 957 of those leadership positions. 
judicially appointed to leadership positions; the defendant hires the law firm directly and different partners may spearhead distinct matters. So, evidence of repeat play by those attorneys' law firms was more indicative for defendants: of the 414 available leadership positions, attorneys from repeatplayer defense firms occupied 341 , or $82.3 \%$, of those leadership roles. The 19 defense firms whose attorneys occupied five or more leadership positions claimed $41.5 \%$ of those roles. A list of defense-side repeat-player law firms with the greatest number of appearances appears subsequently in Table 4.

While this Article focuses on nonclass proceedings, information on repeat play in class-action settlements occurring within multidistrict proceedings nevertheless provides some useful comparisons. Class actions tended to have fewer leadership positions, ranging from 22 at the high end to 4 at the low end, and averaging 11.5 positions per proceeding, $43.9 \%$ of which were filled with repeat players. By contrast, plaintiffs' leadership positions in nonclass cases ranged from 62 in the pelvic-mesh cases (American Medical Systems, Ethicon, Boston Scientific, and C.R. Bard) at the high end to 3 positions (Coloplast and Zimmer Durom Hip Cup) or 1 firm (Mirapex) at the low end. ${ }^{108}$ Nonclass multidistrict litigations averaged 21.9 positions per proceeding, $75.2 \%$ of which were filled with repeat players. Excluding the unusually high number of pelvicmesh appointments (in American Medical Systems, Ethicon, Boston Scientific, and C.R. Bard) lowers the average number of positions to 15.9 , with repeat players occupying 61\%. More detailed information on the level of repeat play by proceeding appears subsequently in Table 5 .

\section{B. The Network Methodology}

We used a social network analysis to depict the connections between lawyers and multidistrict proceedings. Network analysis has long been used to study relationships between leaders such as judges and corporate board members. ${ }^{109}$ Not only does graphing the network demonstrate if there are inter-

108 The New England Compounding litigation was excluded from these calculations given its unique bankruptcy status.

109 See Katz \& Stafford, supra note 16, at 457; Garry Robins \& Malcolm Alexander, Small Worlds Among Interlocking Directors: Network Structure and Distance in Bipartite Graphs, 10 COMPUTATIONAL \& MATHEMATICAL ORG. THEORY 69, 74 (2004). This work builds on the early contributions of Jacob Moreno, who pioneered networks analysis's use in diagramming social relationships between individuals holding leadership positions. JACOB L. MOREno, Who SHALl SuRVIVE? A NEW APPROACH TO THE PROBLEM OF HUMAN INTERRELATIONS 86, 153 (1934). 
connections within data (or not), the graphs can highlight the relative importance of a set of entities to the larger group, such as particular multidistrict proceedings or attorneys within those proceedings. ${ }^{110}$

Accordingly, we built an adjacency matrix and employed a two-mode (actors and events) projection of a bipartite network, also known as an affiliation network, to graph the ties between lawyers judicially appointed to leadership positions (the actors) in multidistrict proceedings (the events). ${ }^{111}$ Bipartite networks avoid the loss-of-information problems sometimes associated with converting an affiliation matrix to one-mode data. ${ }^{112}$ As corporate boards do for corporations, lead lawyers make the full range of pretrial litigation decisions for all of the plaintiffs within the group and, because leaders are judicially appointed, we know exactly who is and is not a member, which gives the network clear boundaries (also known as edges). ${ }^{113}$

While we cannot identify friendship, cooperation, or even contrarians by looking directly at the actors, we can look at agents' ties to one another and generate hypotheses about their influence on both social connections and legal norms. ${ }^{114}$ For example, our network graphs formal affiliations based on leadership appointments, but friendships, joint ventures, and rivalries may contribute to or result from these formal appointments. ${ }^{115}$ While some social network studies anticipate linkages and hierarchies, ${ }^{116}$ we make no such assumptions about the structure of leaders at the outset. Instead, by looking at statistical measures of degree centrality (the number of connections a node-attorney or proceeding-makes), betweenness centrality (how often a node is on a path between two other nodes), and eigen values (how close one powerful node is to another), we can begin to understand how the network formed, and who is most important within it. From there

110 DAvid Knoke \& JAMEs H. KuKLINSKI, Network ANALYSIS 50-59 (1982).

111 See M. E. J. Newman, The Structure and Function of Complex Networks, 45 SOC'Y FOR INDUS. \& APPLIED MATHEMATICS REV. 167, 174, 204 (2003) (discussing the use of bipartite graphs for mapping social networks).

112 See Stephen P. Borgatti et Al., Analyzing Social Networks 239 (2013).

113 See Robins \& Alexander, supra note 109, at 74.

114 See BORGATTI ET AL., supra note 112, at 232 ("In analyzing two-mode data, we typically [assume] that attending the same event is either an indicator of an underlying social relationship between the actors or a potential opportunity for one to develop.").

115 See KADUSHIN, supra note 19, at 122-23.

116 E.g., Salmon A. Shomade \& Roger E. Hartley, The Application of Network Analysis to the Study of Trial Courts, 31 JusT. SYS. J. 144 (2010) (anticipating linkages between groups from courts' unification plans). 
we can formulate and explore hypotheses about control, influence, and power as well as theoretical propositions about information flow, norm development, and norm entrenchment. ${ }^{117}$ We provide an overview of network terminology below in Table 2.118

\section{TABLE 2: SOCIAL NETWORK TERMINOLOGY}

\begin{tabular}{|ll|}
\hline $\begin{array}{l}\text { Social } \\
\text { network term }\end{array}$ & Applied definition \\
\hline Node & An attorney or multidistrict proceeding in the network \\
\hline Centrality & $\begin{array}{l}\text { The position of a node (attorney or proceeding) in the network; } \\
\text { more central nodes have more potential to influence others, act as } \\
\text { gatekeepers, and receive "flows" such as information or financial } \\
\text { support; central actors tend to have more social capital }\end{array}$ \\
\hline $\begin{array}{l}\text { Degree } \\
\text { centrality }\end{array}$ & $\begin{array}{l}\text { Indicates how many ties one attorney or proceeding has to other } \\
\text { attorneys or proceedings within the data; nodes with high degree } \\
\text { centrality tend to be those that insiders might flag as integral to } \\
\text { complex proceedings }\end{array}$ \\
\hline $\begin{array}{l}\text { Betweenness } \\
\text { centrality }\end{array}$ & $\begin{array}{l}\text { Indicates how often a node is on the shortest path to other nodes } \\
\text { (think of a bridge, for example); nodes with high betweenness }\end{array}$ \\
$\begin{array}{l}\text { centrality tend to have a high potential for gatekeeping or toll- } \\
\text { taking and have power because they can filter, distort, or threaten } \\
\text { to stop transmitting information }\end{array}$ \\
\hline $\begin{array}{l}\text { Eigen value } \\
\text { centrality }\end{array}$ & $\begin{array}{l}\text { Indicates how close one node is to other well-connected nodes; } \\
\text { nodes with high eigen values tend to indicate popularity-they } \\
\text { connect to well-connected others }\end{array}$ \\
\hline
\end{tabular}

In the context of multidistrict proceedings, these network insights are especially important. As other studies have shown, attorneys in multidistrict litigation are repeat players. ${ }^{119}$ The more often they appear in proceedings, the more likely they are to be appointed to leadership positions, and being in leadership means having the opportunity to play for rules. As we discussed in subpart I.C, the same attorneys appearing in multiple proceedings could have advantages and disadvantages. Leadership consistency offers a number of benefits, both to the litigants who rely on experienced repeat players to win their case and net a high reward, and to judges who may have handled few, if any, multidistrict proceedings and perceive the attorneys as a reliable source of casemanagement information.

Of course, repeat players' informational advantage may also have a downside: less high-profile attorneys who have extensive experience in the trenches of discovery committees

117 See BORGATTI ET AL., supra note 112, at 164.

118 This table uses information from BORGATTI ET AL., supra note 112, at 163-75, to summarize definitional concepts.

119 Burch, supra note 20, at 96-97; Nagareda, supra note 50, at 141. 
are closed out of opportunities to gain leadership experience, leaders' perspectives and heuristics may be less diverse, and, even when privy to unique information that others lack, attorneys may not share it for fear the dominant group member will disapprove. ${ }^{120}$ Such dissent might be particularly useful in both ensuring adequate representation for "outliers" (plaintiffs with idiosyncratic injuries or circumstances) and for the group as a whole.

Knowing what the network looks like and who is key within it provides additional information to researchers examining the role of attorneys in multidistrict litigation. Before we delve into the network, however, a word of caution is in order. While our list of products-liability proceedings contains a substantial number of the cases centralized by the Panel as well as a substantial number of the attorneys in those proceedings, it is not exhaustive. Without a complete list of all proceedings, it is difficult to speculate about how important specific attorneys or litigations are to the entire world of complex litigation. As such, our discussion focuses on the importance of attorneys and proceedings in the network created with our data. The scope of the data suggests that the results are generalizable outside the realm of products liability (and indeed the results below are consistent with past work), but we cannot say with certainty that what we find is true across all proceeding types, or even for all products-liability cases for all time. Nonetheless, the importance of products-liability proceedings to the larger world of civil litigation suggests this is an appropriate starting place to examine attorneys' relationships as well as their influence.

\section{Results}

\section{The Social Network}

Using our database of 73 products-liability and sales-practices multidistrict litigations, we graphed the network among the participating lead lawyers. Our data include plaintiff and defense attorneys, the leadership roles they held, how many total appearances they make in the data, the size of the proceeding, and how many appearances the attorney's firm made. While snapshots of each of our graphs appear below, readers interested in a searchable, magnified view of the labels (which indicate individual attorneys and proceedings) in the network

120 See Cass R. Sunstein, Going to Extremes: How Like Minds Unite And Divide 28-29 (2009); Burch, supra note 20, at 98-101. 
can download the original images. ${ }^{121}$ Our look at the connections among attorneys is purely exploratory. Graphing the network among entities provides insights into data that cannot be seen in thousands of rows; it shows us what's hidden in plain sight. Still, our work is meant to generate hypotheses, not to test them per se.

FIGURE 2: LEAD LAWYER NETWORK, PRODUCTS-LIABILITY AND SALESPRACTICE MULTIDISTRICT PROCEEDINGS

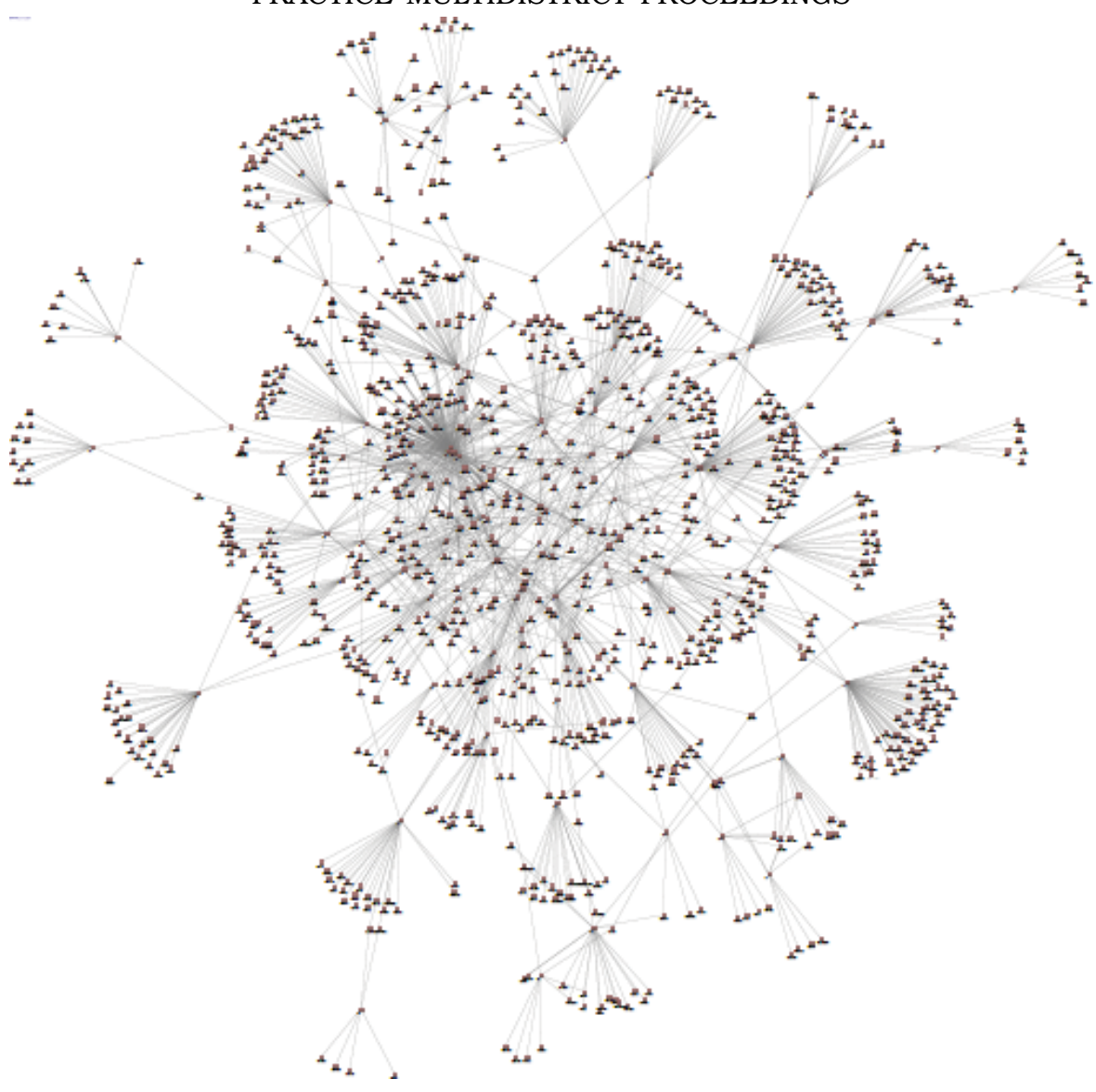

The network created among lead products-liability lawyers in our data is quite cohesive. As Figure 2 above shows, there is a single densely populated network, and two much smaller isolated networks on the periphery. The smaller networks include litigation over Porsche's plastic coolant tubes ${ }^{122}$ and the

121 Downloadable and searchable graphs are available under the "multidistrict litigation" category at https://perma.cc/CB 2X-VWG4.

122 In re Porsche Cars N. Am., Inc. Plastic Coolant Tubes Prods. Liab. Litig., No. 11-md-2233 (S.D. Ohio 2012). 
Factor VII or IX blood products litigation. ${ }^{123}$ These two litigations do not share any leadership counsel common to the rest of the larger network. Unlike many other proceedings in our data, the blood products litigation involved only three lead lawyers and contained 337 total actions, making it a relatively small proceeding in both overall size and number of leadership counsel. Porsche Cars featured the unusual event of a judge appointing an entire firm co-lead counsel. The whole proceeding encompassed only eight actions, again making it a small proceeding relative to others in our data. The size of the proceedings suggests that they are outliers as they may not present the case management challenges typical of most multidistrict products-liability proceedings.

The larger network features more of the principal productsliability proceedings that appear in the academic literature and in media coverage. Both proceedings and attorneys have key roles in the network's cohesion. Four of the pelvic-mesh cases are in the center of the network, ${ }^{124}$ and most connections radiate from this core set of proceedings. The pelvic-mesh cases comprise $55 \%$ of all cases pending in multidistrict proceedings-the largest grouping since the asbestos litigations. ${ }^{125}$ Given the number of participating attorneys and the appointment of the same 62 attorneys to leadership in four of the five pelvic-mesh proceedings, this is hardly surprising. What is interesting, however, is how these proceedings feature some but not all of the attorneys most central to the network. Looking specifically at degree centrality emphasizes this point.

123 In re Factor VIII or IX Concentrate Blood Prods. Liab. Litig., No. 986 (N.D. Ill. 1996).

124 In re Boston Sci. Corp. Pelvic Repair Sys. Prods. Liab. Litig., No. 2326 (S.D. W. Va. 2016); In re C.R. Bard, Inc. Pelvic Repair Sys. Prods. Liab. Litig., No. 2187 (S.D. W. Va. 2014); In re Ethicon, Inc. Pelvic Repair Sys. Prods. Liab. Litig., No. 2327 (S.D. W. Va. 2014); In re Am. Med. Sys., Inc. Pelvic Repair Sys. Prods. Liab. Litig., No. 2325 (J.P.M.L. 2012).

125 See Distribution of Pending MDL Dockets by District, JUDICIAL PANEL ON MULTIDISTRICT LITIG. (Oct. 15 2015) [https://perma.cc/EZ7N-QVCM]. 
FIGURE 3: LEAD LAWYER NETWORK, PRODUCTS-LIABILITY AND SALESPRACTICE MULTIDISTRICT PROCEEDINGS, DEGREE

CENTRALITY HIGHLIGHTED

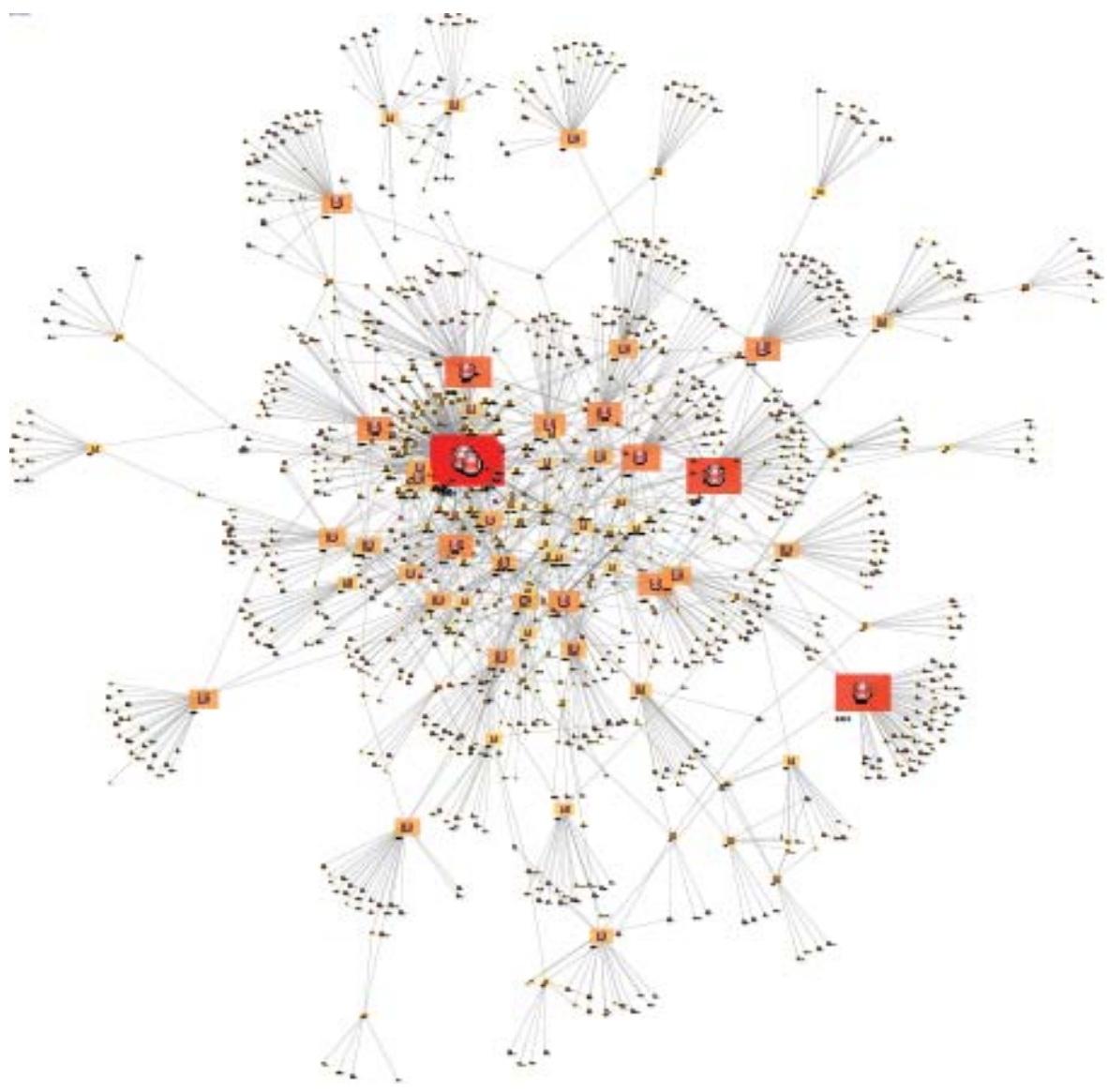

Figure 3 above highlights degree centrality. In general, the more central a node (actor or event) is to a network, the more opportunities it has to influence others and receive information and support from others in the network. ${ }^{126}$ That, in turn, gives those actors social capital; people who are more central to a network may have opportunities and advantages that those on the periphery lack. ${ }^{127}$ Higher degree centrality-the number of ties a node has to other nodes-may indicate influential insiders who are well positioned to control how information flows over the network and to spin that information in ways that benefit them. ${ }^{128}$ As such, the literature on repeat players sug-

126 See BORGATTI ET AL., supra note 112, at 164.

127 See id.

128 See id. at 164-65. 
gests that degree centrality is a particularly apt measurement: attorneys appointed as leaders in more proceedings can make more connections. ${ }^{129}$

Those events with the highest degree centrality include four of the pelvic-mesh proceedings ${ }^{130}$ and litigation against the New England Compounding Pharmacy. ${ }^{131}$ The attorneys with the highest degree centrality include Richard Arsenault, Daniel Becnel, Jr., Dianne Nast, Christopher Seeger, and Jerrold Parker. Many of these attorneys appear in a substantial number of proceedings, both generally and in our data specifically. Arsenault is featured in eighteen proceedings in our data, Seeger appears in sixteen, Becnel and Nast each appear in fourteen, and Parker appears in eleven. They are well connected, so to speak, and presumably exhibit judicially preferred characteristics of experience, cooperative tendencies, and an ability to finance the litigation.

Interestingly, however, the proceedings in which these attorneys appear are not the same. Becnel and Seeger do not appear as leaders in any of the five proceedings with the highest degree centrality: the pelvic-mesh cases against C.R. Bard, ${ }^{132}$ American Medical Systems, ${ }^{133}$ Boston Scientific, ${ }^{134}$ and Ethicon, ${ }^{135}$ or the New England Compounding Pharmacy litigation. ${ }^{136}$ In fact, what links these two lawyers with the rest of the network is their participation in Accutane. ${ }^{137}$ Of the eleven proceedings most central to the network (based on all measures of centrality) Becnel appears in only two and Seeger appears in only one. It appears that the importance of these two attorneys to this network is in linking those proceedings

129 See Williams et al., supra note 20, at 158.

130 In re Boston Sci. Corp. Pelvic Repair Sys. Prods. Liab. Litig., No. 2326 (S.D. W. Va. 2016); In re C.R. Bard, Inc., Pelvic Repair Sys. Prods. Liab. Litig., No. 2187 (S.D. W. Va. 2014); In re Ethicon, Inc. Pelvic Repair Sys. Prods. Liab. Litig., No. 2327 (S.D. W. Va. 2014); In re Am. Med. Sys., Inc. Pelvic Repair Sys. Prods. Liab. Litig., No. 2325 (J.P.M.L 2012).

131 In re New England Compounding Pharmacy, Inc. Prods. Liab. Litig., No. 1:13-md-2419 (D. Mass. 2013).

132 In re C.R. Bard, Inc., Pelvic Repair Sys. Prods. Liab. Litig., No. 2187 (S.D. W. Va. 2014).

133 In re Am. Med. Sys., Inc. Pelvic Repair Sys. Prods. Liab. Litig., No. 2325 (J.P.M.L. 2012).

134 In re Boston Sci. Corp. Pelvic Repair Sys. Prods. Liab. Litig., No. 2326 (S.D. W. Va. 2016).

135 In re Ethicon, Inc. Pelvic Repair Sys. Prods. Liab. Litig., No. 2327 (S.D. W. Va. 2014).

136 In re New England Compounding Pharmacy, Inc. Prods. Liab. Litig., No. 1:13-md-2419 (D. Mass. 2013).

137 In re Accutane (Isotrentinoin) Prods. Liab. Litig., No. 1626, No. 8:04-md2523 (M.D. Fla. 2012). 
and attorneys in the upper right portion of the network to the central nest. Extending this analysis to other types of multidistrict proceedings may show a different pattern.

\section{FIGURE 4: LEAD LAWYER NETWORK, PRODUCTS-LIABILITY AND}

SALES-PRACTICE MULTIDISTRICT PROCEEDINGS, BETWEENNESS HIGHLIGHTED

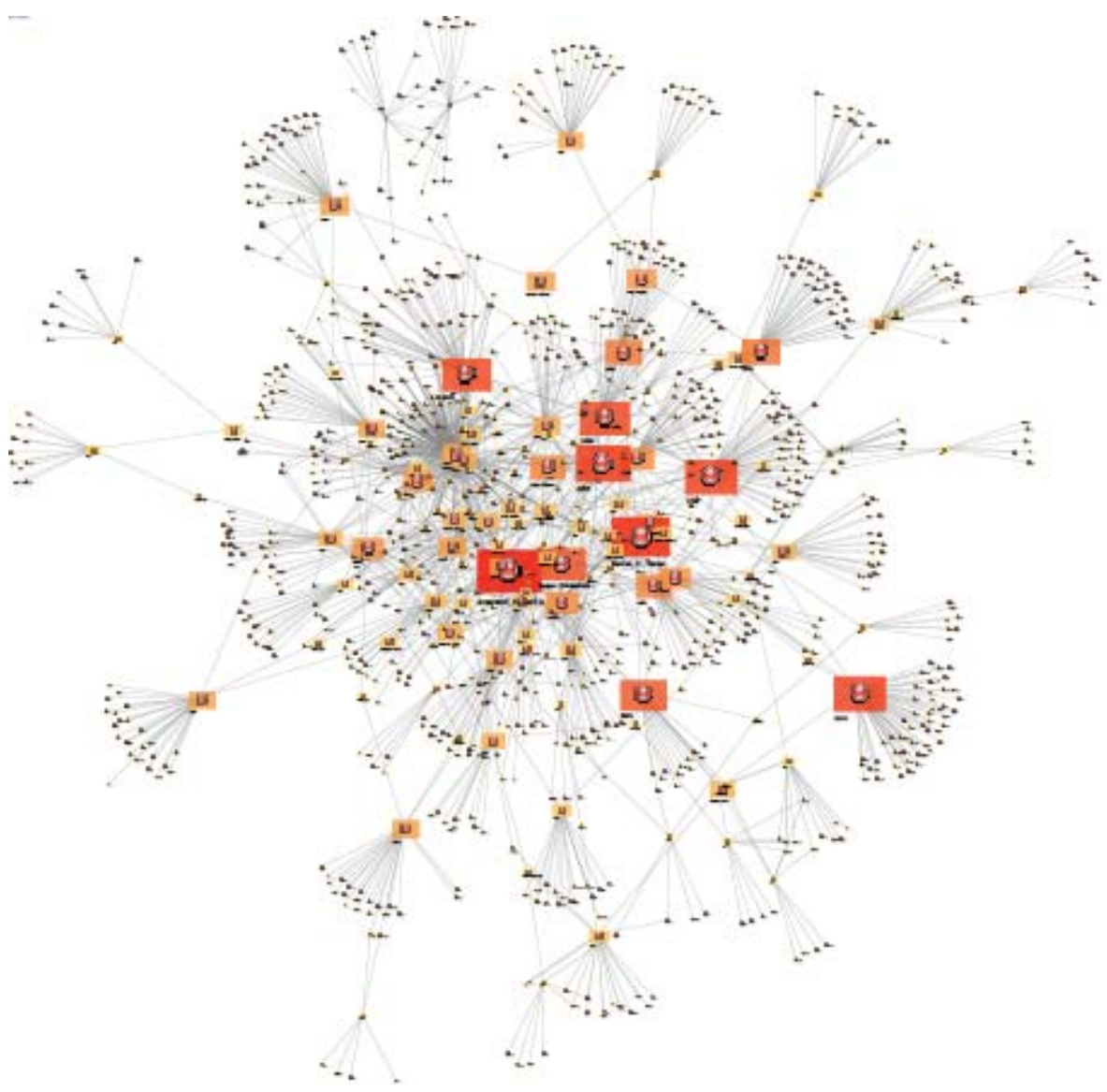

Figure 4 illustrates betweenness. Betweenness centrality measures how often a given attorney or proceeding falls along the shortest path to other attorneys or proceedings. ${ }^{138}$ It helps to identify which events or actors might play either a gatekeeping or toll-taking role, for nodes with high betweenness rank-

138 See BORGATTI ET AL., supra note 112, at 174; Katz \& Stafford, supra note 16, at 495 ("[B]etweenness centrality is often used to identify the bridges between different communities and clusters. To identify these gatekeepers, betweenness calculates the shortest paths (known as geodesics) between all pairs of vertices, identifies the frequency of each node appearing on those paths, then normalizes the statistic."). 
ings can act as information brokers-relaying, distorting, or disrupting the information they pass to others. ${ }^{139}$ When attorneys form the shortest distance from one attorney to the next, they might engage in rent extraction or gatekeeping; the efficiency of the network requires information to flow through them, which increases their power within the network. These lawyers join otherwise disparate groups. Attorneys with high betweenness rankings may likewise broker litigation financing arrangements between plaintiffs' law firms or negotiate global settlements.

Looking at the betweenness ranking, we find a list of lead attorneys similar to those in the degree centrality discussion, but a different list of proceedings. While New England Compounding Pharmacy is also on this list, ${ }^{140}$ the other proceedings are different, including Accutane, ${ }^{141}$ Fosamax, ${ }^{142}$ Propecia, ${ }^{143}$ and Yasmin/Yaz. ${ }^{144}$ Interestingly, unlike the degree centrality list (composed of the pelvic-mesh cases-involving a medical device), here we see pharmaceutical litigations. The attorney list-Richard Arsenault, Daniel Becnel, Jr., Dianne Nast, Joe Rice, and Christopher Seeger-is almost exactly the same, with the exception of Joe Rice appearing in place of Jerrold Parker. Rice makes an interesting series of connections in the network, tying the largest multidistrict litigation of all time, Asbestos, ${ }^{145}$ and litigation over BP's Deepwater Horizon Oil Spill ${ }^{146}$ to all other proceedings. Without his appearance in leadership in both proceedings, neither Deepwater Horizon nor Asbestos would connect to the rest of the nest in our data.

Overall, the network shows a strong, cohesive center, where attorneys participate in leadership in many multidistrict proceedings, and a set of attorneys with relatively few connections, both to proceedings and other lead lawyers. To clarify the center of the network, we kept the attorneys participating

139 See BORGATTI ET AL., supra note 112, at 174-75.

140 In re New England Compounding Pharmacy, Inc. Prods. Liab. Litig., No. 1:13-md-2419 (D. Mass. 2013).

141 In re Accutane (Isotrentinoin) Prods. Liab. Litig., No. 1626, No. 8:04-md2523 (M.D. Fla. 2012).

142 In re Fosamax Prods. Liab. Litig., No. 06-md-1789 (S.D.N.Y 2014).

143 In re Propecia (Finasteride) Prods. Liab. Litig., No. 12-md-02331 (E.D.N.Y. 2013).

144 In re Yasmin and Yaz (Drospirenone) Mktg., Sales Pract. \& Prods. Liab. Litig., No. 09-md-02100 (S.D. Ill. 2010).

145 In re Asbestos Prods. Liab. Litig. (No. VI), No. 875, No. 2:02-md-875 (E.D. Pa. 2013).

146 In re Oil Spill by the Oil Rig "Deepwater Horizon" in the Gulf of Mexico on April 20, 2010, No. 10-md-02179 (E.D. La. 2012). 
in leadership in two or more multidistrict litigations in our data (thereby excluding 786 attorneys, or $78 \%$ of the data) and regraphed the network, which appears below. ${ }^{147}$

FIGURE 5: ATTORNEYS WITH TWO OR MORE LEADERSHIP APPEARANCES, PRODUCTS-LIABILITY AND SALES-PRACTICES MULTIDISTRICT PROCEEDINGS

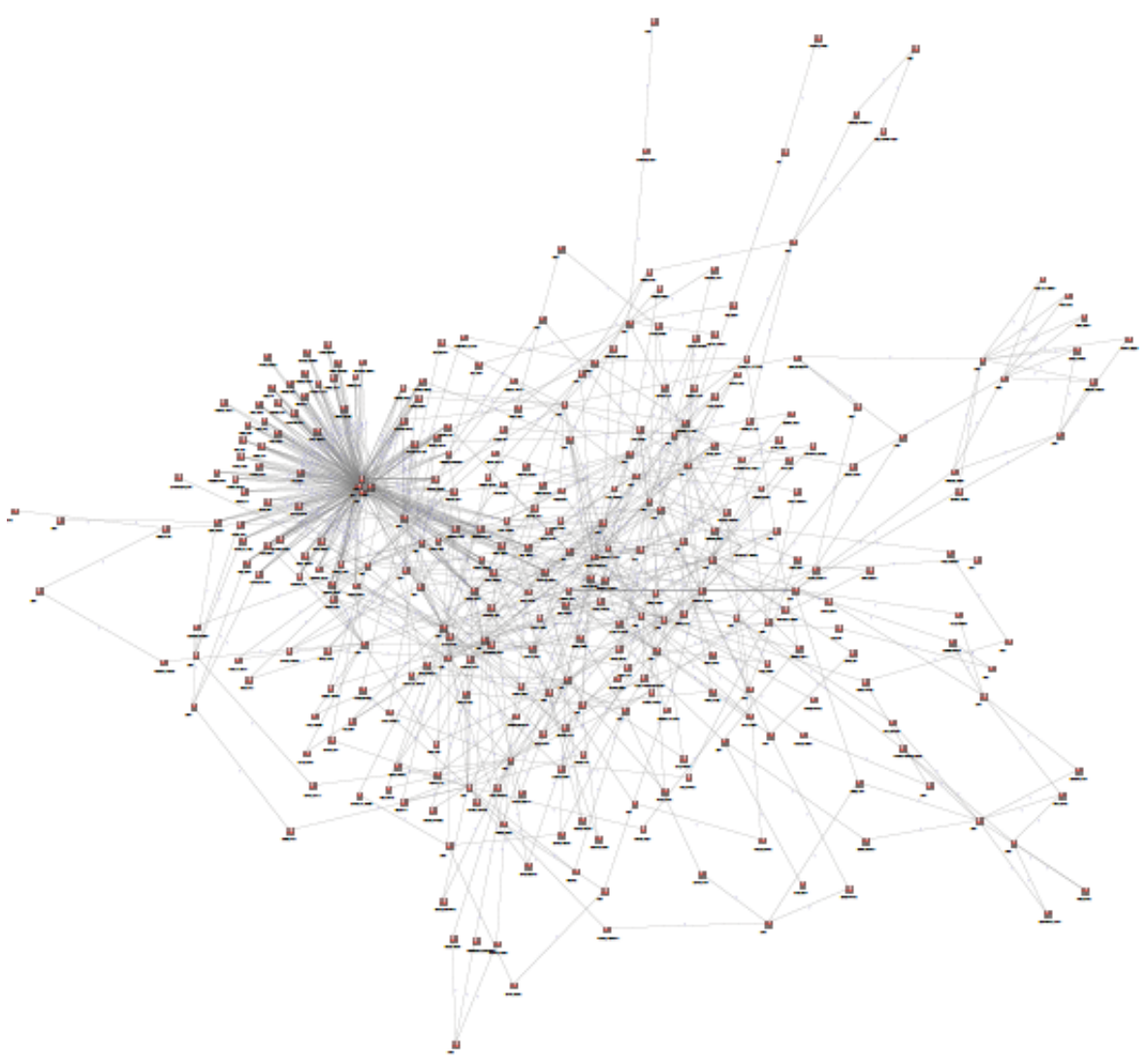

If we focus on the attorneys with at least two leadership appearances, we see a similar picture. Figure 5 above shows the same network after removing all the attorneys who appear as leaders in only one multidistrict proceeding in our data. This figure shows more clearly how closely related four of the

147 Pruning nodes is a well-established and recommended approach to analyze large networks. BORGATTI ET AL., supra note 112, at 252. 
pelvic-mesh litigations ${ }^{148}$ are to each other in terms of the participating attorneys. In fact, as Figure 6 below shows, if we look at the entities with the highest eigen values (attorneys and proceedings closest to other key attorneys and proceedings), we find that those four proceedings include all five attorneys who have the highest eigen values: Richard Arsenault, Dianne Nast, Jerrold Parker, Jane Conroy, and Michelle Parfitt.

Figure 6 illustrates how much pull those four pelvic-mesh proceedings have on the current picture of multidistrict litigation provided by our data. Highlighting eigen value indicates a way to consider an attorney's importance in a relative way: how important are the attorneys to which that attorney is connected? ${ }^{149}$ While degree centrality measures the number of connections, and betweenness measures how key an attorney is to connecting other parts of the network efficiently, eigen value considers the importance of the connections an attorney makes. It is perhaps here where the centers of power are most likely to be seen. The four pelvic-mesh proceedings, and the attorneys participating in them, are central to the network of all attorneys with a leadership role in two or more products-liability proceedings. This is likely in part because so many of the attorneys in one pelvic-mesh litigation are in another (which is why they rank so highly in degree centrality), but also because these cases involve some of the attorneys most common to all multidistrict products-liability proceedings. In other words, the related nature of the pelvic-mesh proceedings strengthens ties among lawyers who were already interacting with each other more than one would find outside the realm of complex litigation.

148 In re Am. Med. Sys., Inc. Pelvic Repair Sys. Prods. Liab. Litig., No. 2325 (J.P.M.L 2012); In re Boston Sci. Corp. Pelvic Repair Sys. Prods. Liab. Litig., No. 2326 (S.D. W. Va. 2016); In re C.R. Bard, Inc., Pelvic Repair Sys. Prods. Liab. Litig., No. 2187 (S.D. W. Va. 2014); In re Ethicon, Inc. Pelvic Repair Sys. Prods. Liab. Litig., No. 2327 (S.D. W. Va. 2014).

149 See Williams et al., supra note 20, at 158. 
FIGURE 6: ATTORNEYS WITH TWO OR MORE LEADERSHIP APPEARANCES IN PRODUCTS-LIABILITY OR SALES-PRACTICES MULTIDISTRICT LITIGATIONS, EIGEN VALUE HIGHLIGHTED

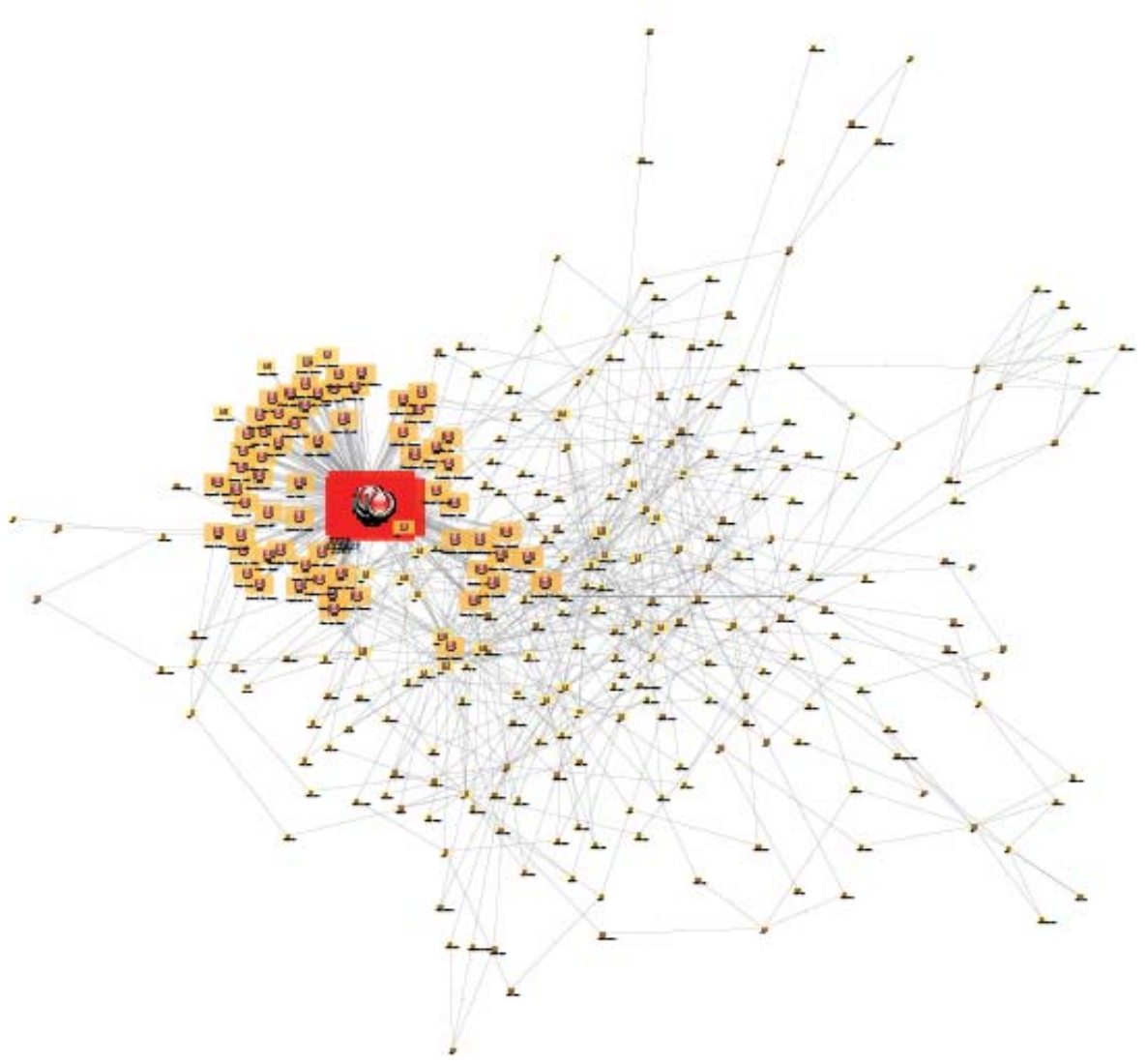

\section{Centrality's Importance to Leadership Selection}

What do these interlocking connections mean in practice and how do they affect the nature of the proceedings themselves? The relative importance of lead attorneys to the overall network only begins to tell the story of the role these repeat players have in the world of multidistrict litigation, for all kinds of things can flow through a network-money, trust, influence, information, reputations, and even sanctions. ${ }^{150}$ Each and every tie provides leaders with opportunities to influence and be influenced. And, as Professor Stanley Milgram demon- 
strated with his famous crowd experiment (where research assistants stared up at a nearby window on a city street), the more people who exhibit a particular behavior, the more likely others are to copy that behavior. ${ }^{151}$ Add to that that interconnected agents can have emergent properties-that networked people can demonstrate complicated, shared behavior without explicitly coordinating with each other-and hypotheses about the potential for norm development and entrenchment can be extensive. ${ }^{152}$

What we can determine with certainty is that attorneys with more appearances in proceedings are more likely to be appointed to leadership positions, and attorneys in leadership design master settlement agreements. If we look specifically at the type of leadership roles we can begin to separate those making the rules from those merely playing by them. All the attorneys in our network served in some leadership position within a multidistrict litigation, but even among this highly experienced group of attorneys there are those who appear more often than others. Table 3 below shows how much leadership experience the top twenty-five repeat plaintiffs-side players in our dataset have, followed by Table 4 , which illustrates the leadership experience among the defense bar by firm. ${ }^{153}$

151 CHRISTAKIS \& FOWLER, supra note 18, at 24.

152 See id. at 26 (discussing emergent properties and likening them to more than the sum of their parts-"A cake has a taste not found in any one of its ingredients").

153 Judicial appointments to leadership roles on the defense side are rare and typically used only in cases where the number of defendants requires more formal coordination. More comprehensive lists of leadership appearances by the top 50 attorneys in our data, as well as firm experience, is available in the Appendix. 
Table 3: High-Level Repeat Players - Plaintiffs' Counsel

\begin{tabular}{|c|c|c|c|c|c|c|c|}
\hline Attorney & 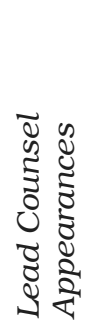 & 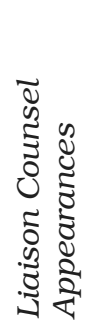 & 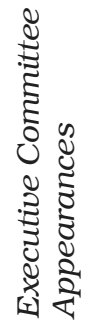 & 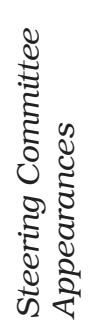 & 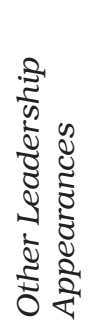 & 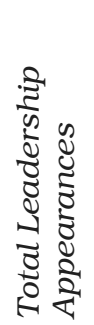 & 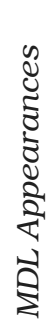 \\
\hline Arsenault, Richard & 3 & 1 & 2 & 13 & 2 & 21 & 18 \\
\hline Seeger, Christopher & 1 & 2 & 3 & 12 & 2 & 21 & 16 \\
\hline Nast, Dianne & 2 & 1 & 2 & 12 & 2 & 19 & 14 \\
\hline Becnel, Jr., Daniel & 0 & 1 & 2 & 11 & 0 & 14 & 14 \\
\hline Parker, Jerrold & 0 & 0 & 1 & 10 & 0 & 11 & 11 \\
\hline Conroy, Jayne & 1 & 1 & 1 & 8 & 1 & 12 & 10 \\
\hline Parfitt, Michelle & 0 & 1 & 2 & 8 & 0 & 11 & 10 \\
\hline Levin, Arnold & 2 & 1 & 1 & 8 & 3 & 15 & 9 \\
\hline Robinson, Jr., Mark & 2 & 1 & 2 & 7 & 2 & 14 & 10 \\
\hline London, Michael & 2 & 2 & 2 & 7 & 1 & 14 & 9 \\
\hline Crump, Martin & 0 & 0 & 1 & 7 & 0 & 8 & 8 \\
\hline DeBartolomeo, A.J. & 0 & 0 & 0 & 7 & 0 & 7 & 7 \\
\hline Flaherty, Yvonne & 0 & 0 & 0 & 7 & 0 & 7 & 7 \\
\hline Osborne, Joseph & 0 & 0 & 0 & 7 & 0 & 7 & 7 \\
\hline Thompson III, Fred & 3 & 1 & 1 & 6 & 1 & 12 & 8 \\
\hline Shkolnik, Hunter & 1 & 0 & 1 & 6 & 1 & 9 & 8 \\
\hline Restaino, John & 1 & 0 & 1 & 6 & 2 & 10 & 7 \\
\hline Cartmell, Thomas & 0 & 0 & 2 & 6 & 0 & 8 & 7 \\
\hline Dugan, II, James & 0 & 0 & 0 & 6 & 1 & 7 & 7 \\
\hline Zonies, Joseph & 0 & 0 & 1 & 6 & 0 & 7 & 6 \\
\hline Abrams, Rachel & 0 & 0 & 0 & 6 & 0 & 6 & 6 \\
\hline Blizzard, Edward & 0 & 0 & 0 & 6 & 0 & 6 & 6 \\
\hline Oliver, Alyson & 0 & 0 & 0 & 6 & 0 & 6 & 6 \\
\hline Lanier, W. Mark & 1 & 0 & 3 & 5 & 2 & 11 & 8 \\
\hline Flowers, Peter & 1 & 0 & 2 & 5 & 0 & 8 & 7 \\
\hline
\end{tabular}

Table 4: High-Level Repeat Player Defense Firms with Five OR MORE LEADERSHIP APPEARANCES

\begin{tabular}{|c|c|c|}
\hline Defense Law Firm & $\begin{array}{l}\text { Attorney MDL } \\
\text { Appearances }\end{array}$ & Multidistrict Proceedings \\
\hline Venable LLP & 23 & $\begin{array}{l}\text { Fosamax (MDL 1789) } \\
\text { Mirapex } \\
\text { Propecia (Finasteride) } \\
\text { Nexium (Esomeprazole) }\end{array}$ \\
\hline Williams \& Connolly LLP & 13 & $\begin{array}{l}\text { Prempro } \\
\text { Vioxx } \\
\text { Chantix } \\
\text { Nexium (Esomeprazole) }\end{array}$ \\
\hline Bryan Cave LLP & 12 & $\begin{array}{l}\text { Ford Motor Co. E-350 Van (No. II) } \\
\text { Fosamax (MDL 1789) } \\
\text { Bisphenol-A (BPA) Polycarbonate Plastics } \\
\text { Propecia (Finasteride) } \\
\text { Pradaxa (Dabigatran Etexilate) }\end{array}$ \\
\hline
\end{tabular}




\begin{tabular}{|c|c|c|}
\hline Defense Law Firm & $\begin{array}{l}\text { Attorney MDL } \\
\text { Appearances }\end{array}$ & Multidistrict Proceedings \\
\hline Butler Snow LLP & 12 & $\begin{array}{l}\text { Fosamax (MDL 1789) } \\
\text { Ethicon, Inc. Pelvic Repair Sys. } \\
\text { Propecia (Finasteride) } \\
\text { Tylenol (Acetaminophen) Marketing }\end{array}$ \\
\hline Ulmer \& Berne LLP & 12 & $\begin{array}{l}\text { Celexa and Lexapro } \\
\text { Yasmin and Yaz (Drospirenone) Marketing } \\
\text { Darvocet, Darvon and Propoxyphene } \\
\text { Watson Fentanyl Patch }\end{array}$ \\
\hline Covington \& Burling LLP & 10 & $\begin{array}{l}\text { Accutane (Isotrentinoin) } \\
\text { Fosamax (MDL 1789) } \\
\text { Pradaxa (Dabigatran Etexilate) } \\
\text { Nexium (Esomeprazole) }\end{array}$ \\
\hline Tucker Ellis LLP & 10 & $\begin{array}{l}\text { OrthoEvra } \\
\text { DePuy Orthopaedics Inc., ASR Hip Implant } \\
\text { Propecia (Finasteride) } \\
\text { Coloplast Corp. Pelvic Support Sys. } \\
\text { New England Compounding Pharmacy, Inc. }\end{array}$ \\
\hline Fulbright \& Jaworski LLP & 9 & $\begin{array}{l}\text { Fosamax (MDL 1789) } \\
\text { Denture Cream } \\
\text { Coloplast Corp. Pelvic Support Sys. } \\
\text { New England Compounding Pharmacy, Inc. }\end{array}$ \\
\hline McGuire Woods LLP & 7 & $\begin{array}{l}\text { ConAgra Peanut Butter } \\
\text { New England Compounding Pharmacy, Inc. }\end{array}$ \\
\hline $\begin{array}{l}\text { Skadden, Arps, Slate, } \\
\text { Meagher \& Flom LLP }\end{array}$ & 7 & $\begin{array}{l}\text { Toyota Motor Corp. Unintended Acceleration } \\
\text { Darvocet, Darvon and Propoxyphene } \\
\text { DePuy Orthopaedics, Inc., Pinnacle Hip } \\
\text { Implant } \\
\text { New England Compounding Pharmacy, Inc. }\end{array}$ \\
\hline Baker \& Daniels LLP & 6 & $\begin{array}{l}\text { Zimmer Durom Hip Cup } \\
\text { Zimmer Nexgen Knee Implant }\end{array}$ \\
\hline Ice Miller LLP & 6 & $\begin{array}{l}\text { Accutane (Isotrentinoin) } \\
\text { Darvocet, Darvon and Propoxyphene }\end{array}$ \\
\hline Jones Day & 6 & $\begin{array}{l}\text { Mentor Corp. ObTape Transobuturator Sling } \\
\text { Nexium (Esomeprazole) }\end{array}$ \\
\hline $\begin{array}{l}\text { Nelson Mullins Riley \& } \\
\text { Scarborough LLP }\end{array}$ & 6 & $\begin{array}{l}\text { FEMA Trailer Formaldehyde } \\
\text { C.R. Bard, Inc., Pelvic Repair System } \\
\text { Boston Scientific Corp Pelvic Repair Sys. } \\
\text { Whirlpool Corp. Front-Loading Washer }\end{array}$ \\
\hline Reed Smith & 6 & $\begin{array}{l}\text { Mirapex } \\
\text { Kugel Mesh Hernia Patch } \\
\text { Fosamax (Alendronate Sodium) (No. II) } \\
\text { NuvaRing } \\
\text { American Medical Systems Inc., Pelvic } \\
\text { Repair Sys. }\end{array}$ \\
\hline Drinker Biddle \& Reath LLP & 5 & $\begin{array}{l}\text { OrthoEvra } \\
\text { Levaquin } \\
\text { DePuy Orthopaedics Inc., ASR Hip Implant } \\
\text { Tylenol (Acetaminophen) Marketing } \\
\text { Propulsid }\end{array}$ \\
\hline $\begin{array}{l}\text { Halleland Lewis Nilan \& } \\
\text { Johnson }\end{array}$ & 5 & $\begin{array}{l}\text { Mirapex } \\
\text { Levaquin } \\
\text { Baycol }\end{array}$ \\
\hline McDermott, Will, \& Emery & 5 & $\begin{array}{l}\text { Diet Drugs (Phentermine/Fenfluramine/ } \\
\text { Dexfenfluramine) } \\
\text { Methyl Tertiary Butyl Ether (“MTBE”) } \\
\text { IKO Roofing Shingle }\end{array}$ \\
\hline Wheeler Trig O'Donnell LLP & 5 & $\begin{array}{l}\text { Gadolinium Contrast Dyes } \\
\text { Whirlpool Corp. Front-Loading Washer }\end{array}$ \\
\hline
\end{tabular}


Typically, highly experienced attorneys serve on a steering committee in addition to serving in one other leadership position within a proceeding. ${ }^{154}$ The attorneys shown to be central to the network above have the greatest amount of experience in leadership positions as well. Again, while these results are not surprising (more experience in these proceedings means more opportunities for leadership, and one leadership appointment makes the next leadership appointment more likely), it is important to point out that attorneys who are central to a network of products-liability proceedings are not only powerful for their connections to other attorneys, but for their leadership in conducting and shaping the proceedings. These attorneys broker the master settlements that resolve these cases. This raises the question of what their deals look like, as well as the unanswerable question about how those deals might differ if courts appointed non-central attorneys to leadership.

EMPIRICALly ASSESSING THE DEALS THOSE REPEAT PLAYERS DESIGN

How might well-connected lead lawyers' ties affect the settlements they design? As Professors Nicholas Christakis and James Fowler demonstrated, social networks can have profound effects on people's lives-they can spread joy and health and help us understand how markets and democracies function, but they can also spread things like depression, violence, and even suicide. ${ }^{155}$ They find that all social networks "tend to magnify whatever they are seeded with."156 We can only guess at the seeds in multidistrict litigation. As Part I explained, transferee judges try to select cooperative, experienced, and well-financed leaders and presumably encourage efficiency in accordance with the authorizing statute's mission. ${ }^{157}$ But, because all of these leaders are agents, we must

154 We might begin to think of this as positional inequality-the notion that some are better off based on where they are located within the network. Their situational inequality might be causally related to positional inequality, for if judges routinely select those attorneys with more financial means (situational inequality due to socioeconomics) then they are likely to be better connected positionally within the network. See CHRISTAKIS \& FOWLER, supra note 18, at 31.

155 CHRISTAKIS \& FOWLER, supra note 18, at 31.

156 Id.

15728 U.S.C. § 1407(a) (2012) (authorizing the Panel to transfer cases when doing so "will promote the just and efficient conduct of such actions"). 
also consider the possibility of a more troubling seed: an agent may better herself at her principal's expense.

To be clear, there is no way for us to reliably test what flows through our network. ${ }^{158}$ By looking at the settlements that well-connected leaders implement and the fee practices they influence, however, we can formulate better-informed hypotheses about the network's effects. Using a variety of sources (including media stories and docket entries from the proceedings), we analyzed the publicly available nonclass settlements that resulted within our dataset, the accompanying lead lawyers' common-benefit fee awards, and the attorneys in leadership roles who designed the settlements. Specifically, as indicia of advantages that repeat players might enjoy that oneshotters do not, we looked for provisions that one might argue principally benefit the lead lawyers and the defendants, and not necessarily the plaintiffs. We focused our inquiry on four main types of provisions: (1) those that induce claimants to settle and thereby generate closure for defendants; (2) those compensating lead lawyers; (3) those that allow unclaimed funds to revert to the defendant; and (4) those that reduce payout amounts to latecomers who do not have counsel as of the settlement date.

This enterprise has two notable caveats. First, settlement provisions designed to induce claimants to settle can deliver closure that unlocks gains for the settling plaintiffs that may not exist otherwise-a "peace premium." 159 Defendants, particularly those with publicly traded stock, are often eager to end lawsuits and ease shareholders' minds about future business prospects. In class actions, defendants accomplished closure through a combination of preclusion doctrines and walkaway provisions, which allowed defendants to withdraw the settlement offer if too many class members opted out. The need for finality persists even when multidistrict litigation concludes through a nonclass, aggregate settlement. But, without a certified class, closure requires more creativity in settlement design. The trouble comes both in the lack of structural assurances of adequate representation in appointing leaders on the front end, and on the back end in policing the line between acceptable settlement tactics that rational claimants should accept because the offer is too good to decline and those that

158 We do not have access to attorneys' financial assets, for example, and for reasons explored elsewhere, attorneys are unlikely to be candid if interviewed. See Burch, supra note 71, at 155-58.

159 Nagareda, supra note 50, at 162. 
claimants can't refuse in The Godfather sense-a gun to the head accompanied by assurances that either the person's signature or brains would appear on the contract. ${ }^{160}$

Second, lead lawyers may perform the lion's share of the work in any given multidistrict litigation, and they should be compensated for their performance insofar as it benefits claimants. ${ }^{161}$ But allowing lead lawyers to negotiate their fees with the defendant-either by inserting fee-related provisions within the settlement or by having the defendant pay their fees directly-is troubling. Leadership fees are big business: using a settlement agreement to contract around the initial judicial fee award in Guidant, for example, boosted lead lawyers' fees by $\$ 29.7$ million. ${ }^{162}$ And while defendants must be on board with the deal, they are not naïve; fee provisions may cost them nothing if they come from the plaintiffs' share of the funds, yet defendants receive a powerful bargaining chip that they might exchange for things like lower settlement amounts, higher participation rates, or stringent criteria to qualify for settlement money. ${ }^{163}$ Moreover, through settlement consent, lead lawyers might be able to tax state-court plaintiffs who eluded federal jurisdiction and the transferee judge's common-benefit assessment. Perhaps lead lawyers confer a benefit here as well, but the fee assessments are typically uniform and not tailored to quantum-meruit principles. ${ }^{164}$

Class settlements can include coercive provisions designed to deliver closure, too. ${ }^{165}$ In the Sulzer hip implant litigation, for example, defendant Sulzer hired Dickie Scruggs, a noted plaintiffs' attorney, to design a class settlement that minimized opt outs. ${ }^{166}$ Among other provisions, that settlement placed liens on virtually all the defendants' assets in favor of settling class members such that the opt outs would have to wait at least six years before receiving payment. ${ }^{167}$ And if Sulzer set-

160 Richard Nagareda has written about class action provisions extensively in these terms. Richard A. Nagareda, Closure in Damage Class Settlements: The Godfather Guide to Opt-Out Rights, 2003 U. CHI. LEGAL F. 141 (2003).

161 See Burch, supra note 20, at 130-35.

162 In re Guidant Corp. Implantable Defibrillators Prods. Liab. Litig., No. 05md-1708, 2008 WL 682174, at *2-4, 16 (D. Minn. Mar. 7, 2008); Burch, supra note 20 , at 81 .

163 See Silver \& Miller, supra note 11, at 134.

164 See Burch, supra note 20, at 103-09, 128-35.

165 For an in-depth overview of these provisions, see Nagareda, supra note 50, at 204-19.

166 Jess Bravin, Sulzer Medica Reaches Novel Class-Action Pact, WALL ST. J., Aug. 16, 2001, at A1.

167 In re Inter-Op Hip Prosthesis Liab. Litig., 204 F.R.D. 330, 354 (E.D. Ohio 2001). 
tled with an opt-out claimant on more favorable terms than those in the settlement, it would have to pay all participating class members more as well. ${ }^{168}$ Functioning a bit like a doomsday device that would never actually be triggered, the idea was to signal to opt-outs that they would never receive a better deal than what the settlement offered. As Scruggs described it, "[I]f anybody opts out, they still have to try their case, win their case, win their appeal, and then there would be no assets to satisfy their judgment, because they are all pledged to the class." 169

But the circumstances in multidistrict proceedings make closure and fee-related clauses even more troubling. In Sulzer, objectors (whose attorneys stood to gain fees only if their objection improved the deali70) challenged the legitimacy of those provisions on appeal, which led settlement designers to boost benefits to class members, change the deal's questionable provisions, and remove the lien-all before the Sixth Circuit could rule on the original settlement. ${ }^{171}$ Nonclass aggregate settlements, by contrast, are private deals with no appellate review to correct error or threaten change. Judges do not ensure the settlement is fair under Rule 23(e), subject lead lawyers to adequate representation scrutiny under Rule 23(a)(4), or have explicit control over attorneys' fees under Rule 23(h). As such, nonclass settlements lack key structural failsafes. Thus, clauses that appear to principally benefit the attorneys rather than their clients raise significant concerns.

Turning to the settlements themselves, of the seventy-three products-liability and sales-practices multidistrict litigations in our dataset, we were able to obtain private, nonclass settlements in ten multidistrict litigations (three of which generated two settlements each for a total of thirteen settlements), ${ }^{172}$ class settlements in twenty, and one bankruptcy-related settlement. ${ }^{173}$ One of the nonclass settlements (in the American Medical Systems litigation) is a partial settlement: it covers

168 Id.

169 Bravin, supra note 166, at Al.

170 See, e.g., Rodriguez v. Disner, 688 F.3d 645, 659-60 (9th Cir. 2012) (noting that when objectors confer a benefit on the class, they should receive attorneys' fees).

171 See Nagareda, supra note 50, at 205 n.240 (2003) ("A preliminary ruling by the Sixth Circuit did not bode well for that court's ultimate disposition of the settlement and, as such, spurred negotiations that ultimately recast the deal.").

172 Propulsid, DePuy ASR Hip Implant, and Yasmin/Yaz each generated two settlement agreements.

173 For an overview of the proceedings' resolutions, see supra Figure 1 and accompanying text. 
only the claimants represented by two law firms, not all the pending claims. Because the other settlements in that case were confidential, we could not determine whether that settlement was representative of the others. Twenty-one other multidistrict litigations in our data have also settled; however, those aggregate settlements were confidential and nonpublic.

Because this Article focuses on the practices and norms that develop outside of directly authorized judicial supervision under established class-action principles, we limited our analysis to the thirteen publicly available nonclass settlements that resulted from ten multidistrict litigations. Our analysis, while limited, nevertheless provides some interesting insights into what the settlements brokered by repeat players look like. And though the number of publicly available private settlements was relatively small, the proceedings in which those settlements occurred collectively included 64,107 total actions. ${ }^{174}$ Table 5, infra, shows the settlements in our data by settlement date, from oldest to newest. We indicate the settlements we examined using boldface type.

174 Using the most recent data available on the proceedings, the Pending MDLs by District as of July 15, 2016 (or our earlier 2013 information where the proceedings were no longer pending), the proceedings contained the following number of actions: Propulsid 474, Vioxx 10,320, Fosamax 1,141, Yasmin/Yaz 11,858, DePuy ASR 9,877, Biomet 2,607, NuvaRing 1,895, Actos 5,111, American Medical Systems 20,231, and Zimmer Durom 593. 


\section{TABle 5: AgGREgate SetTlements OCCURRING WITHIN THE Dataset By SETtlement Date (AS OF July 15, 2016)}

\begin{tabular}{|c|c|c|c|c|c|c|}
\hline $\begin{array}{l}\text { MDL } \\
\text { Number }\end{array}$ & MDL Name & 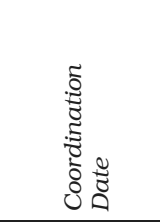 & 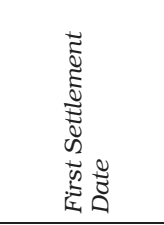 & 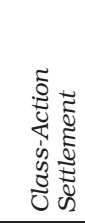 & 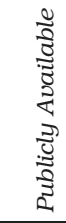 & 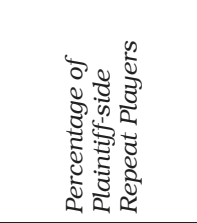 \\
\hline 875 & Asbestos & $7 / 29 / 91$ & $1980 \mathrm{~s}$ & No & No & $16 \%(2 / 12)$ \\
\hline 986 & $\begin{array}{l}\text { Factor VII or IX } \\
\text { Concentrate Blood } \\
\text { Prods. }\end{array}$ & $12 / 7 / 1993$ & $5 / 8 / 1997$ & Yes & Yes & $15 \%(2 / 13)$ \\
\hline 1203 & $\begin{array}{l}\text { Diet Drugs } \\
\text { (Phentermine, } \\
\text { Fenfluramine, } \\
\text { Dexfenfluramine) }\end{array}$ & $1 / 6 / 1998$ & $1 / 3 / 2002$ & Yes & Yes & $15 \%(2 / 13)$ \\
\hline 1355 & Propulsid & $8 / 7 / 2000$ & $4 / 30 / 2004$ & No & Yes & $90 \%(10 / 11)$ \\
\hline 1431 & Baycol & $12 / 18 / 01$ & $6 / 30 / 2005$ & No & No & $68 \%(15 / 22)$ \\
\hline 1657 & Vioxx & $2 / 16 / 2005$ & $11 / 9 / 2007$ & No & Yes & $50 \%(14 / 28)$ \\
\hline 1742 & Ortho Evra & $3 / 1 / 2006$ & $10 / 13 / 2008$ & No & No & $71 \%(15 / 21)$ \\
\hline 1836 & Mirapex & $6 / 22 / 2007$ & $2 / 29 / 2009$ & No & No & $100 \%(1 / 1$ firm $)$ \\
\hline 1909 & $\begin{array}{l}\text { Gadolinium } \\
\text { Contrast Dyes }\end{array}$ & $2 / 29 / 2008$ & $4 / 15 / 2009$ & No & No & $72 \%(13 / 18)$ \\
\hline 1845 & $\begin{array}{l}\text { ConAgra Peanut } \\
\text { Butter }\end{array}$ & $6 / 17 / 2007$ & $5 / 29 / 2009$ & No & No & $26 \%(5 / 19)$ \\
\hline 1763 & Human Tissue & $6 / 13 / 2007$ & $1 / 30 / 2010$ & No & No & $33 \%(2 / 6)$ \\
\hline 1871 & Avandia & $6 / 11 / 07$ & $6 / 01 / 2010$ & No & No & $79 \%(19 / 24)$ \\
\hline 2004 & $\begin{array}{l}\text { Mentor Corp. } \\
\text { ObTape }\end{array}$ & $12 / 3 / 08$ & $6 / 8 / 2010$ & No & No & $66 \%(4 / 6)$ \\
\hline 1928 & Trasylol & $4 / 7 / 2008$ & $7 / 6 / 2010$ & No & No & $62 \%(10 / 16)$ \\
\hline 1967 & $\begin{array}{l}\text { Bisphenol-A } \\
\text { Polycarbonate } \\
\text { Plastic }\end{array}$ & $8 / 13 / 2008$ & $1 / 3 / 2011$ & Yes & Yes & $22 \%(2 / 9)$ \\
\hline 1873 & $\begin{array}{l}\text { FEMA Trailer } \\
\text { Formaldehyde }\end{array}$ & $10 / 24 / 2007$ & $3 / 14 / 2011$ & Yes & Yes & $18 \%(2 / 11)$ \\
\hline 1842 & $\begin{array}{l}\text { Kugel Mesh Hernia } \\
\text { Patch }\end{array}$ & $6 / 22 / 2007$ & $7 / 1 / 2011$ & No & No & $75 \%(9 / 12)$ \\
\hline 1953 & Heparin & $6 / 6 / 2008$ & $12 / 1 / 2011$ & No & No & $57 \%(12 / 21)$ \\
\hline 2188 & $\begin{array}{l}\text { Apple iPhone } 4 \\
\text { Marketing \& Sales } \\
\text { Practices }\end{array}$ & $10 / 8 / 2010$ & $1 / 1 / 2012$ & Yes & Yes & $0 \%(0 / 4)$ \\
\hline 2179 & Deepwater Horizon & $8 / 10 / 2010$ & $4 / 18 / 2012$ & Yes & Yes & $36 \%(7 / 19)$ \\
\hline 2308 & $\begin{array}{l}\text { Sketchers Toning } \\
\text { Shoe }\end{array}$ & $12 / 19 / 2011$ & $5 / 02 / 2012$ & Yes & Yes & $80 \%(4 / 5)$ \\
\hline 2023 & $\begin{array}{l}\text { Bayer Corp. } \\
\text { Combination } \\
\text { Aspirin }\end{array}$ & $4 / 14 / 2009$ & $5 / 16 / 2012$ & Yes & Yes & $50 \%(6 / 12)$ \\
\hline 1507 & Prempro & $3 / 4 / 2003$ & $6 / 8 / 2012$ & No & No & $12.5 \%(3 / 24)$ \\
\hline 2047 & Chinese Drywall & $1 / 13 / 2010$ & $6 / 14 / 2012$ & Yes & Yes & $70.5 \%(12 / 17)$ \\
\hline 1958 & Zurn Pex Plumbing & $8 / 21 / 2008$ & $10 / 15 / 2012$ & Yes & Yes & $70 \%(7 / 10)$ \\
\hline 2284 & Imprelis Herbicide & $10 / 20 / 2011$ & $10 / 19 / 2012$ & Yes & Yes & $60 \%(3 / 5)$ \\
\hline 1943 & Levaquin & $6 / 13 / 2008$ & $10 / 30 / 2012$ & No & No & $62 \%(5 / 8)$ \\
\hline 2223 & $\begin{array}{l}\text { Navistar Diesel } \\
\text { Engine }\end{array}$ & $4 / 13 / 2011$ & $11 / 1 / 2012$ & Yes & Yes & $44 \%(8 / 18)$ \\
\hline 2151 & $\begin{array}{l}\text { Toyota Motor Corp. } \\
\text { Unintended } \\
\text { Acceleration }\end{array}$ & $4 / 9 / 2010$ & $12 / 26 / 2012$ & Yes & Yes & $40.9 \%(9 / 22)$ \\
\hline 2092 & $\begin{array}{l}\text { Chantix } \\
\text { (Varenicline) }\end{array}$ & $10 / 1 / 2009$ & $1 / 15 / 2013$ & No & No & $75 \%(12 / 16)$ \\
\hline
\end{tabular}




\begin{tabular}{|c|c|c|c|c|c|c|}
\hline $\begin{array}{l}\text { MDL } \\
\text { Number }\end{array}$ & MDL Name & 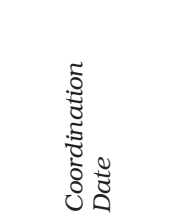 & 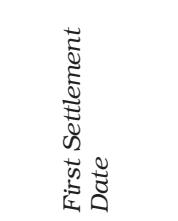 & 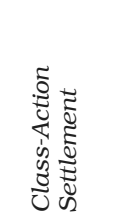 & 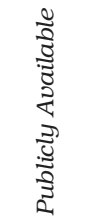 & 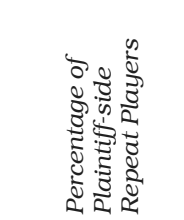 \\
\hline 2100 & $\begin{array}{l}\text { Yasmin and Yaz } \\
\text { (Drospirenone) }\end{array}$ & $10 / 1 / 2009$ & $3 / 15 / 2013$ & No & Yes & $89 \%(17 / 19)$ \\
\hline 2372 & $\begin{array}{l}\text { Watson Fentanyl } \\
\text { Patch }\end{array}$ & $8 / 7 / 2012$ & $6 / 4 / 2013$ & No & No & $0 \%(0 / 8)$ \\
\hline 2233 & $\begin{array}{l}\text { Porsche Plastic } \\
\text { Coolant Tubes }\end{array}$ & $5 / 23 / 2011$ & $7 / 26 / 2013$ & Yes & Yes & $0.07 \%(1 / 13)$ \\
\hline 2197 & $\begin{array}{l}\text { DePuy ASR Hip } \\
\text { Implant }\end{array}$ & $12 / 3 / 2010$ & $11 / 11 / 2013$ & No & Yes & $80 \%(25 / 31)$ \\
\hline 1789 & Fosamax & $11 / 21 / 2011$ & $12 / 9 / 2013$ & No & Yes & $66 \%(8 / 12)$ \\
\hline 2325 & $\begin{array}{l}\text { American Medical } \\
\text { Systems }\end{array}$ & $2 / 7 / 12$ & $4 / 30 / 2013$ & No & Semi $^{\mathrm{a}}$ & $100 \%(62 / 62)$ \\
\hline 2008 & $\begin{array}{l}\text { Land Rover LR3 } \\
\text { Tire Wear }\end{array}$ & $2 / 23 / 09$ & $5 / 30 / 2013$ & Yes & Yes & $66 \%(4 / 6)$ \\
\hline 2391 & $\begin{array}{l}\text { Biomet Magnum } \\
\text { Hip Implant }\end{array}$ & $10 / 2 / 2012$ & $1 / 31 / 2014$ & No & Yes & $58 \%(14 / 24)$ \\
\hline 1964 & NuvaRing & $8 / 22 / 2008$ & $2 / 7 / 2014$ & No & Yes & $35 \%(6 / 17)$ \\
\hline 1629 & Neurontin & $10 / 26 / 2004$ & $5 / 30 / 2014$ & Yes & Yes & $50 \%(4 / 8)$ \\
\hline 2385 & Pradaxa & $8 / 8 / 2012$ & $5 / 28 / 2014$ & No & No & $70 \%(19 / 27)$ \\
\hline 2387 & $\begin{array}{l}\text { Coloplast Corp. } \\
\text { Pelvic Support Sys. }\end{array}$ & $8 / 6 / 2012$ & $9 / 22 / 2014$ & No & No & $100 \%(3 / 3)$ \\
\hline 2333 & $\begin{array}{l}\text { MI Windows \& } \\
\text { Doors }\end{array}$ & $4 / 23 / 12$ & $12 / 24 / 2014$ & Yes & Yes & $46 \%(6 / 13)$ \\
\hline 2419 & $\begin{array}{l}\text { New England } \\
\text { Compounding } \\
\text { Pharmacy }\end{array}$ & $2 / 12 / 2013$ & $2 / 13 / 2015$ & Bankr. & Yes & $42.8 \%(3 / 7)$ \\
\hline 2283 & $\begin{array}{l}\text { Building Materials } \\
\text { Corp. of Am. }\end{array}$ & $10 / 11 / 11$ & $4 / 22 / 2015$ & Yes & Yes & $69 \%(9 / 13)$ \\
\hline 2327 & $\begin{array}{l}\text { Ethicon, Inc. Pelvic } \\
\text { Repair }\end{array}$ & $2 / 7 / 2012$ & $3 / 10 / 2015$ & No & No & $100 \%(62 / 62)$ \\
\hline 2299 & $\begin{array}{l}\text { Actos } \\
\text { (Pioglitazone) }\end{array}$ & $12 / 29 / 2011$ & $4 / 29 / 2015$ & No & Yes & $68 \%(18 / 22)$ \\
\hline 2187 & $\begin{array}{l}\text { C.R. Bard, Inc. } \\
\text { Pelvic Repair Sys. }\end{array}$ & $10 / 12 / 2010$ & $6 / 23 / 2015$ & No & No & $98 \%(62 / 63)$ \\
\hline 2326 & $\begin{array}{l}\text { Boston Scientific } \\
\text { Corp. Pelvic Repair } \\
\text { Sys. }\end{array}$ & $2 / 7 / 2012$ & $12 / 7 / 2015$ & No & No & $100 \%(62 / 62)$ \\
\hline 2316 & $\begin{array}{l}\text { Ford Motor Co. } \\
\text { Spark Plug \& 3- } \\
\text { Valve Engine }\end{array}$ & $2 / 8 / 2012$ & $1 / 26 / 2016$ & Yes & Yes & $83 \%(5 / 6)$ \\
\hline 2158 & $\begin{array}{l}\text { Zimmer Durom } \\
\text { Hip Cup }\end{array}$ & $9 / 9 / 2010$ & $2 / 11 / 2016$ & No & Yes & $100 \%(3 / 3)$ \\
\hline 2100 & $\begin{array}{l}\text { Whirlpool Corp. } \\
\text { Front Loading } \\
\text { Washer }\end{array}$ & $12 / 20 / 2008$ & $5 / 11 / 2016$ & Yes & Yes & $61 \%(8 / 13)$ \\
\hline
\end{tabular}

a This settlement was included as an exhibit to a Securities and Exchange Commission filing; some confidential parts of it were redacted. The agreement is between American Medical Systems and Freese \& Goss, PLLC and Matthews \& Associates.

b New England Compounding Pharmacy is in the midst of bankruptcy proceedings, so the settlement is a bankruptcy trust. 


\section{A. Settlement Attorneys}

Before examining these thirteen settlements, we must first confirm that the repeat players we previously discussed participated in leadership positions when these agreements were brokered. Not surprisingly, the plaintiffs' attorneys who frequently appeared as leaders in our data were key to these settlements.

The multidistrict proceedings we examined varied in terms of the number of repeat players appointed to leadership positions. Zimmer Durom Hip Cup, American Medical Systems, ${ }^{175}$ and Propulsid were at the high end, with repeat players occupying 100, 100, and 90\% of the plaintiffs' leadership positions, respectively. Yasmin/Yaz and DePuy ASR followed suit with repeat players in 89 and $80 \%$ of those positions. Actos and Fosamax had slightly fewer repeat players, with 68\% in Actos and 66\% in Fosamax. Both Biomet and Vioxx filled around half of the plaintiffs' leadership positions with repeat players-58\% in Biomet and 50\% in Vioxx. And NuvaRing contained the fewest repeat players, with $35 \%$.

What became apparent in reviewing the settlements, however, was that it was not so much the sheer number of repeat players involved in a proceeding that seemingly affected the outcome, but the influence of a relatively small cadre of highlevel, well-connected repeat players occupying the most powerful positions who actively designed and implemented those settlements. Our findings here are consistent with those in other disciplines; in research and development laboratories, for example, about six individuals act as information and technological gatekeepers, or bridges, in network terms. ${ }^{176}$ Table 6 below shows which attorneys with the highest degree centrality (to take one measure) appeared as leaders in the examined settlements.

175 The judge handling pelvic-mesh cases appointed the same sixty-two attorneys as lead lawyers in four out of the five pelvic-mesh multidistrict proceedings he was handling.

176 Thomas J. Allen \& Stephen I. Cohen, Information Flow in Research and Development Laboratories, 14 ADMIN. SCI. Q. 12, 13 (1969). 
TABle 6: PARTICIPATION IN NONCLASS SETtLEMENTS By REPEAT PlAINTIFFS' ATTORNEYS WITH THE HIGHEST

DEGREE CENTRALITY

\begin{tabular}{|c|c|c|c|c|c|c|}
\hline $\begin{array}{c}\text { MDL } \\
\text { Number }\end{array}$ & MDL Name & $\begin{array}{c}\text { Richard } \\
\text { Arsenault }\end{array}$ & $\begin{array}{c}\text { Daniel } \\
\text { Becnel, Jr. }\end{array}$ & $\begin{array}{c}\text { Dianne } \\
\text { Nast }\end{array}$ & $\begin{array}{l}\text { Jerrold } \\
\text { Parker }\end{array}$ & $\begin{array}{c}\text { Christopher } \\
\text { Seeger }\end{array}$ \\
\hline 1355 & Propulsid & Yes & Yes & No & No & Yes \\
\hline 1657 & Vioxx & Yes & No & No & No & Yes \\
\hline 1789 & Fosamax & No & No & No & No & Yes \\
\hline 2100 & $\begin{array}{l}\text { Yasmin and Yaz } \\
\text { (Drospirenone) }\end{array}$ & No & Yes & Yes & No & Yes \\
\hline 2197 & DePuy ASR Hip Implant & Yes & No & No & Yes & Yes \\
\hline 2391 & Biomet Magnum Hip Implant & Yes & No & No & No & No \\
\hline 1964 & NuvaRing & Yes & No & No & No & No \\
\hline 2299 & $\begin{array}{l}\text { Actos (Pioglitazone) } \\
\text { American Medical Sys- }\end{array}$ & Yes & No & Yes & Yes & Yes \\
\hline 2325 & tems ${ }^{177}$ & Yes & No & Yes & Yes & No \\
\hline 2158 & Zimmer Durom Hip Cup & No & No & No & No & Yes \\
\hline
\end{tabular}

\section{B. Settlement Provisions and Lead Lawyers' Fees}

Given the interconnections among these attorneys in our data, it should not be surprising to find commonality in the settlement provisions. What may be surprising, however, is how closely these settlement provisions mirror one another, beginning with the two Propulsid settlements. The Propulsid settlements were the first nonclass settlements in our data, and, as we show, they appear to be the template that repeat players sought to replicate and improve upon in future settlements. As such, we introduce these settlements in detail to highlight the means by which leaders resolved mass litigation without the class device-principally through widespread plaintiff participation requirements. As we note, these settlements not only helped end the litigation for the defendant, but paid plaintiffs' lawyers directly for doing so. The question that lingers, however, is whether these developments benefitted one-shot plaintiffs.

In the first Propulsid settlement, three provisions worked in concert to induce closure. First, the deal required $85 \%$ of those with death claims and $75 \%$ of those with injury claims to enroll in the program before the agreement took effect. ${ }^{178}$ Second, to entice plaintiffs to participate, the settlement escalated the defendant's payment amounts based on higher participa-

177 Note that we have only one of several aggregate settlements negotiated with American Medical Systems. The others are confidential.

178 MDL-1355 Term Sheet § 1.B, In re Propulsid Prods. Liab. Litig., No. 00-md1355 (E.D. La. Apr. 30, 2004) [hereinafter First Propulsid Settlement]. The plaintiffs' steering committee represented about 4,000 people, 300 of whom allegedly died from using Propulsid. Johnson \& Johnson Unit in Legal Settlement Over Propulsid Suit, DATAMONITOR INDUSTRY NEWSWIRE, Mar. 2004. 
tion percentages and included a \$4 million "bonus" if $100 \%$ of non-death claimants enrolled. ${ }^{179}$ Third, an "opt-out" form accompanied the settlement even though the settlement was not a class action and all claimants had to affirmatively "opt in." 180 Designed for plaintiffs who refused to enroll, this form explained that the client's chosen attorney was no longer permitted to represent her under the settlement's terms and authorized counsel to withdraw from the representation. ${ }^{181}$ So, the client was opting out of representation-not just declining the settlement offer.

Somewhat like arbitration, submitting claims to the settlement program extinguished them, win or lose. After four years, the panel of three physicians reviewing claims deemed only 11 of 1,356 claimants eligible for payouts. ${ }^{182}$ Still, the program could not bind absent plaintiffs as a class action does, and the first settlement did not cover 2,000 state-court plaintiffs or 5,000 claimants who had not filed as of February 1, 2004.183

Nevertheless, by using a lodestar analysis that estimated the attorney's fee from the money deposited for awards instead of the money actually paid to claimants, the court awarded the Plaintiffs' Steering Committee a fee of $\$ 22.5$ million. ${ }^{184}$ No one objected. ${ }^{185}$

At the end of the first settlement only 32 out of 4,245 plaintiffs satisfied the settlement's claims criteria and were eligible for relief. ${ }^{186}$ Collectively, those 32 plaintiffs received little more than $\$ 3.66$ million. ${ }^{187}$ The remaining settlement funds went elsewhere: two donations of more than \$8 million each

179 First Propulsid Settlement, supra note 178, § 3.B.

180 Opt Out Form for Propulsid MDL Settlement, In re Propulsid Prods. Liab.

Litig., No. 00-md-1355 (E.D. La. 2004) [http://perma.cc/72JG-APEF].

181 Id.

182 Joint Report 62 at 2, In re Propulsid Prods. Liab. Litig., No. 00-md-1355 (E.D. La. Feb. 26, 2008); Janet McConnaughey, Two Propulsid Settlements; A Handful of Checks, ASSOCIATED PRESS, Feb. 29, 2008.

183 Parties Announce New Propulsid Settlement to Resolve Remaining State, Federal Claims, BNA ClASS ACTION LITIG. RPT., Jan. 27, 2006. Earlier reports estimated that 12,000 people had not yet sued at the time of the first settlement. Johnson \& Johnson Unit in Legal Settlement, supra note 178.

184 In re Propulsid Prods. Liab. Litig., No. 00-md-1355 (E.D. La. June 2, 2005) (order); First Propulsid Settlement, supra note 177, § 19.

185 In re Propulsid Prods. Liab. Litig., No. 00-md-1355 (E.D. La. June 2, 2005) (order) ("No objections were made to the Motion.").

186 Joint Report No. 89 of Plaintiffs' and Defendants Liaison Counsel at 1-2, In re Propulsid Prods. Liab. Litig., No. 00-md-1355 (E.D. La. Feb. 22, 2011 ).

187 See Joint Report No. 97 of Plaintiffs' and Defendants' Liaison Counsel, In re Propulsid Prods. Liab. Litig., No. 00-md-1355 (E.D. La. July 31, 2012). The precise total was $\$ 3,665,167.74$. Not surprisingly, it was not included in the Joint Report but derived from numbers provided in that and previous reports. 
were awarded to Canada's Prepulsid Resolution Program and charitable organizations; ${ }^{188} \$ 40$ million reverted to defendant Johnson \& Johnson; ${ }^{189}$ and $\$ 12$ million remained in the settlement fund. 190

Given the continued need to resolve the remaining claims, in December of 2005, reportedly at the behest of counsel representing state-court plaintiffs, the federal Plaintiffs' Steering Committee and the State Liaison Committee negotiated Propulsid II. This \$15 million settlement mostly mirrored the first one, but required $90 \%$ of death claimants and $95 \%$ of personalinjury claimants to consent before becoming effective. ${ }^{191}$ This time, the physician panel found only 5 out of 1,767 claimants compensable, and Johnson \& Johnson paid slightly more than $\$ 2.85$ million from the settlement fund. ${ }^{192}$ Nevertheless, the Plaintiffs' Steering Committee requested over $\$ 4.1$ million in fees. ${ }^{193}$ Once again, no objections to that motion appeared on the docket, and the court granted the request. ${ }^{194}$ The court also granted a joint motion to revert $\$ 5$ million of the second

188 In re Propulsid Prods. Liab. Litig., No. 00-md-1355 (E.D. La. Nov. 30, 2009) (order granting joint motion for an order authorizing distribution of MDL 1 settlement fund). The money went to Louisiana Health Public Initiative, even though claimants were geographically dispersed throughout the country. Joint Report No. 95 of Plaintiffs' and Defendants' Liaison Counsel, In re Propulsid Prods. Liab. Litig., No. 00-md-1355 (E.D. La. Mar. 6, 2012).

189 Joint Report No. 95 of Plaintiffs' and Defendants' Liaison Counsel, In re Propulsid Prods. Liab. Litig., No. 00-md-1355 (E.D. La. Mar. 6, 2012). Historically, reversion clauses have served as red flags for self-dealing in class settlements. Int'l Precious Metals Corp. v. Walters, 530 U.S. 1223, 1223 (2000) (O'Connor, J., statement respecting the denial of the petition for a writ of certiorari).

190 Joint Motion and Order for Partial Disbursement of Settlement Funds to Defendant Johnson \& Johnson, In re Propulsid Prods. Liab. Litig., No. 00-md1355 (E.D. La. Dec. 14, 201 1); In re Propulsid Prods. Liab. Litig., No. 00-md-1355 (E.D. La. Dec. 19, 2011) (order).

191 Parties Announce New Propulsid Settlement, supra note 183; McConnaughey, supra note 182.

192 The exact number is 2,852,070, and it does not include the 2,059 claimants who enrolled in the program, had their claims extinguished, but did not submit claim forms. Memorandum in Support of Motion for Distribution of Attorney's Fees at 5 and Ex. B (Re: MDL Settlement Program II), In re Propulsid Prods. Liab. Litig., No. 00-md-1355 (E.D. La. 2012).

193 Memorandum in Support of Motion for Distribution of Attorney's Fees Ex. B, In re Propulsid Prods. Liab. Litig., No. 00-md-1355 (E.D. La. Aug. 1, 2012) (re: MDL Settlement Program II).

194 In re Propulsid Prods. Liab. Litig., No. 00-md-1355 (E.D. La. Aug. 22, 2012) (order). The only objections to fee requests that we found were by firms that objected not to the amount of overall fees but to that firm's cut. E.g., Zimmerman Reed P.L.L.P.'s Response in Partial Objection to the Plaintiffs' Steering Committee's Motion for the Distribution of Additional Attorneys' Fees and Reimbursement Costs, In re Propulsid Prods. Liab. Litig., No. 00-md-1355 (E.D. La. Apr. 17, 2012); Objection to the PSC's Motion for Distribution of Specific Attorney's Fees Awards 
settlement fund to the defendant, as well as the remaining balance of all settlement and administrative funds. ${ }^{195}$ As the litigation concluded, lead lawyers requested and received the additional six-percent holdback fund put in place at the beginning of the litigation for common-benefit fee awards, which taxed settlements that occurred before the master settlement agreements, and equaled \$397,860. ${ }^{196}$

The lead lawyers in Propulsid noted that their settlements were the first of their kind to globally resolve mass litigation without the class device and, as such, "promise[d] to become the template" for future cases. ${ }^{197}$ Using Propulsid as a baseline, we examined the other eleven settlements in our database for similar closure and common-benefit fee provisions. We find, overwhelmingly, that the settlement model produced in the Propulsid settlements is carried out in various respects through all other settlements in our database. The principal variations in the other settlements included how many plaintiffs had to participate in the settlement for it to take effect and whether settlement money reverted back to the defendant in the end. Table 7 below shows how the small group of attorneys negotiating, designing, and implementing future settlements in our database consistently applied, again and again, both the closure provisions and the common-benefit fee awards created in Propulsid.

and for Expenses and Reimbursements, In re Propulsid Prods. Liab. Litig., No. 00md-1355 (E.D. La. Apr. 14, 2009) (filed by Lockridge Grindal Nauen P.L.L.P.).

195 In re Propulsid Prods. Liab. Litig., No. 00-md-1355 (E.D. La. Oct. 3, 2012) (order terminating the claims of all enrollees in the Second MDL Resolution Program and authorizing return to the defendants the balance of the settlement fund and administrative fund after all payments due thereunder have been made); In re Propulsid Prods. Liab. Litig., No. 00-md-1355 (E.D. La. Dec. 19, 2011) (order).

196 Plaintiffs' Liaison Counsel's Memorandum in Support of Motion for Final Distribution of Remaining Funds, In re Propulsid Prods. Liab. Litig., No. 00-md1355 (E.D. La. Jan. 31, 2014); In re Propulsid Prods. Liab. Litig., No. 00-md-1355 (E.D. La. Feb. 3, 2014) (order).

197 Memorandum in Support of Plaintiffs' Steering Committees Motion for Award of Attorney's Fees and Reimbursement of Costs, In re Propulsid Prods. Liab. Litig., No. 00-md-1355 (E.D. La. May 3, 2005). 


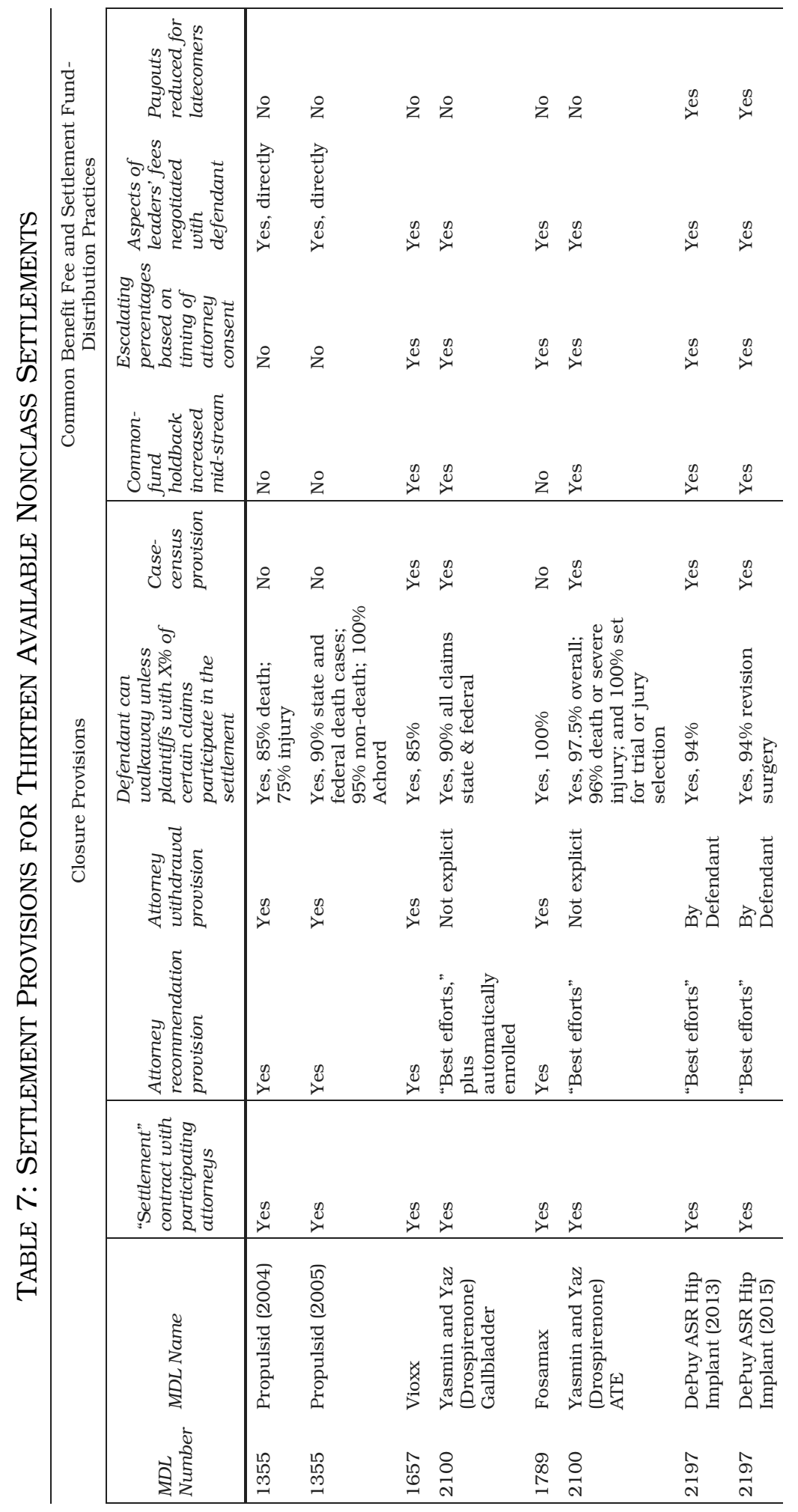




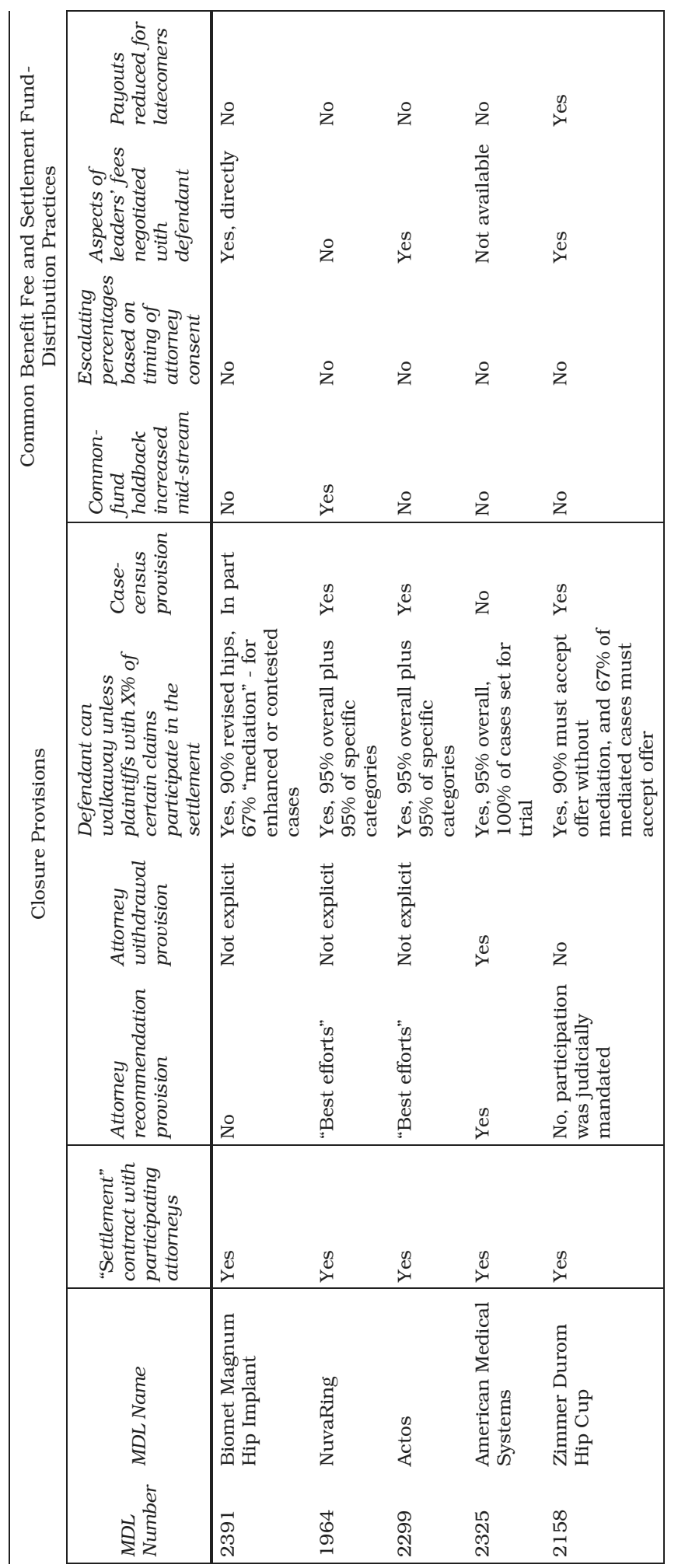


Looking closely at Table 7 above and Figure 7 below shows that even though all the settlements share and replicate certain features, some resemble one another even more closely. Take DePuy ASR, NuvaRing, Actos, and Yasmin/Yaz, for example. All employ what we call "third generation" 198 versions of both attorney-withdrawal provisions and defendant-walkaway provisions in which designers enlist judges to issue "case-census" orders that enable leaders to take stock of both pending and unfiled claims in determining whether plaintiff participation requirements are met. ${ }^{199}$ These four litigations shared a host of common lead lawyers, lead law firms, and claims administrators as Figure 7 below visually demonstrates. For instance, Richard Arsenault was a lead lawyer in DePuy ASR, NuvaRing, and Actos, and Chris Seeger and Mark Robinson, Jr. helped lead DePuy, Yaz, and Actos.

Network models share inherent limitations in depicting real-world events: "nodes" in real life have multiple flows with other nodes, like claims administrators. Figure 7 shows, for example, that BrownGreer, PLC administered all four of these settlements. 
Figure 7: LINKING COMMON ATTORNEYS, FIRMS, AND ADMINISTRATORS IN DEPUY ASR, ACTOS, NUVARING,

AND YASMIN/YAZ

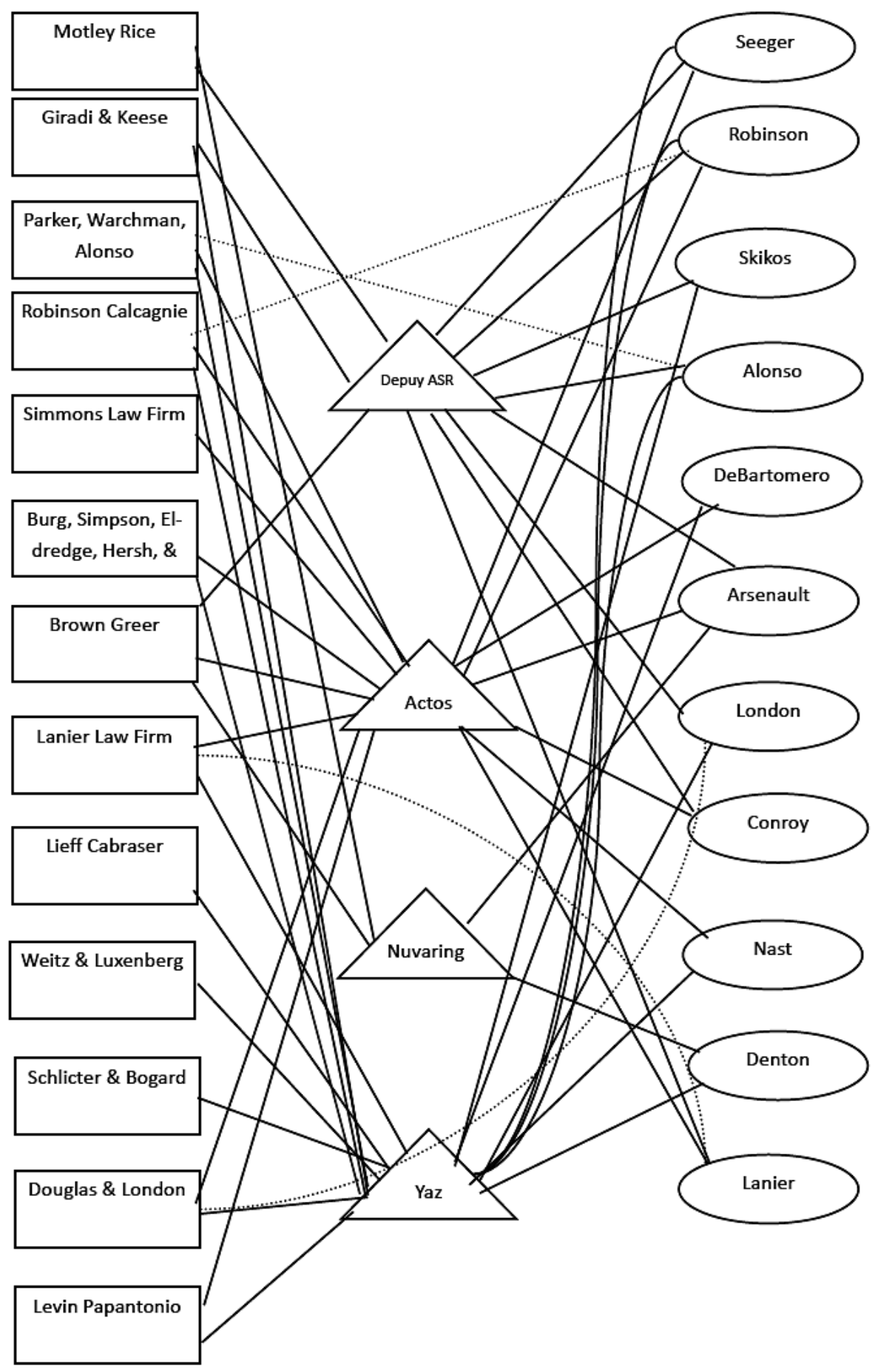




\section{Closure Provisions}

As Propulsid illustrates, without a class-action judgment's claim preclusive effect, settlement designers have experimented with a number of alternative closure devices that are sometimes used alone, and sometimes used in concert with one another. Yet, all the settlements in our database uniformly featured one key departure from conventional settlements: unlike typical settlements between plaintiffs and defendants, these deals were made between lead lawyers and the defendants, and most of them explicitly required the plaintiff's individual attorney to become a signatory if she wanted to enroll a single client in the settlement program. By shifting the dealmaking entity from the client to the lawyer, these offers leveraged the attorney-client relationship itself to achieve closure and tied plaintiffs' attorneys' financial self-interest to one another as opposed to a particular client. Put differently, we saw a uniform departure from the conventional contingent-fee model where an attorney's fees increase solely based on a particular client's outcome.

In common parlance, we refer to these interrelated closure provisions as follows: (1) walkaway provisions, which release the defendant from any contractual obligations if a certain percentage of plaintiffs do not consent to settle; (2) case-census provisions, which rely on the presiding judge to order all attorneys to register their filed and unfiled claims by a certain date such that the defendant can use that number as the denominator in calculating compliance with the walkaway percentage; (3) attorney-recommendation provisions, which require participating attorneys to recommend the deal to all of their clients, and (4) attorney-withdrawal provisions, which instruct attorneys to withdraw from representing clients who do not consent to settle.

Across all the settlements in our database, we found the most common closure provision to be the defendant's ability to walk away from its settlement offer if too few plaintiffs accepted. The threshold for the defendant to abandon the settlement varied somewhat. In Vioxx, if fewer than $85 \%$ of plaintiffs accepted, Merck could walk away and leave the plaintiffs and their attorneys with nothing. ${ }^{200}$ In Fosamax, the stakes were even higher. If a single claimant or attorney failed to sign onto the deal, Merck (again the defendant) could void the agree-

200 Master Settlement Agreement § 1.2.8.1, In re Vioxx Prods. Liab. Litig., No. 05-md-01657 (E.D. La. Feb. 17, 2005) [hereinafter Vioxx Settlement]. 
ment. ${ }^{201}$ Alternatively, Merck could reduce the settlement by however much it would have paid the non-participating claimants (as determined by the allocation committee). ${ }^{202}$ Both $\mathrm{De}$ Puy ASR settlements took a middle path, requiring 94\% of claimants to accept before the deal took effect. ${ }^{203}$

Several settlements included an overall participation threshold as well as specific levels for various claims categories. The two Yasmin/Yaz settlements set the overall walkaway percentage at $90 \%$ of all eligible gallbladder claimants, ${ }^{204}$ and $97.5 \%$ of all arterial-thromboembolic-event ("ATE”) claimants. ${ }^{205}$ But, in the ATE settlement, all plaintiffs set for jury selection or trial had to consent, as did 96\% of plaintiffs with death and severe-injury cases. ${ }^{206}$ Similarly, in American Medical Systems, plaintiffs' attorneys were required to secure releases from $95 \%$ of all claimants plus 100\% of cases set for trial. ${ }^{207}$ In Zimmer Durom Hip Cup, 90\% of all claimants had to accept the defendant's offer without mediation and $67 \%$ of those who opted for mediation had to take the offer or the defendant could terminate the settlement program at its discretion. ${ }^{208}$ Actos and NuvaRing shared nearly identical provisions that included an overall participation rate of $95 \%$ plus $95 \%$ of wrongful-death claims, and $95 \%$ of various specific categories, such as venous thromboembolism and arterial thromboembolism in NuvaRing and cystectomy in Actos. ${ }^{209}$ The thresholds were somewhat lower in Biomet. Biomet had no

201 Master Settlement Agreement II 11, In re Fosamax Prods. Liab. Litig., No. 06-md-1789 (S.D.N.Y. Mar. 24, 2014) (certification and joinder of counsel and claimant's counsel) [hereinafter Fosamax Settlement].

202 Id.

203 Settlement Agreement § 17.1, In re DePuy Orthopaedics, Inc. Hip Implant Prods. Liab. Litig., No. 10-md-2197 (N.D. Ohio Nov. 9, 2013) [hereinafter 2013 DePuy Settlement]; 2015 ASR Settlement Agreement § 17.1, In re DePuy Orthopaedics, Inc. Hip Implant Prods. Liab. Litig., No. 10-md-2197 (N.D. Ohio Mar. 2, 2015) [hereinafter 2015 DePuy Settlement].

204 Settlement Agreement \$§ 9.01, 9.02, In re Yasmin and Yaz (Dropirenone) Mktg., Sales Pract. Prods. Liab. Litig., No. 09-md-2100 (S.D. Ill. Mar. 15, 2013) [hereinafter Yaz Gallbladder Settlement].

205 ATE Master Settlement Agreement §§ 3.01, 3.02, In re Yasmin and Yaz (Dropirenone) Mktg., Sales Pract. Prods. Liab. Litig., No. 09-md-2100 (S.D. Ill. Aug. 3, 2015) [hereinafter Yaz ATE Settlement].

206 Id.

207 Master Settlement Agreement § II.H, In re Am. Med. Sys., Inc. Pelvic Repair Sys. Prods. Liab. Litig., No. 12-md-2325 (S.D. W. Va. June 14, 2013) [hereinafter American Medical Systems Settlement].

208 U.S. Durom Cup Settlement Program Agreement §§ V.A, V.B, In re Zimmer Durom Hip Cup Prods. Liab. Litig., No. 09-cv-04414 (D.N.J. Feb. 11, 2016) [hereinafter Zimmer Durom Settlement].

209 Master Settlement Agreement § 10.02, In re NuvaRing Prods. Liab., No. 08md-1964 (E.D. Mo. Feb. 7, 2014) [hereinafter NuvaRing Settlement]; Master Settle- 
funding obligations without the consent of $90 \%$ of those with revised hips who would receive a base award subject to various deductions, and $67 \%$ of the mediation cases-where one party believed it was entitled to enhanced or reduced payments. ${ }^{210}$

Case-census provisions, a relatively new development, work in concert with walkaway thresholds to create the percentage's denominator. By jointly petitioning both the transferee judge and the coordinating state-court judges, census or "registration" provisions produce case-management orders that require all attorneys who represent a single plaintiff in the issuing courts to register all claims relating to the product in which the attorney has an interest (broadly defined to include "any financial interest of any kind whatsoever") by a certain date. ${ }^{211}$ These orders cover all claims, including those that are unfiled, pending in other courts, or controlled by attorneys who decline to recommend the deal to any client. ${ }^{212}$ Failing to comply with the judicial census triggers a show-cause hearing for counsel to satisfactorily explain the noncompliance or face dismissal. The Vioxx settlement, ${ }^{213}$ both DePuy ASR settlements, ${ }^{214}$ the second Yasmin/Yaz settlement, ${ }^{215}$ the Actos settlement, ${ }^{216}$ the NuvaRing settlement, ${ }^{217}$ and the Zimmer Durom Hip Cup settlement ${ }^{218}$ all featured census provisions. ${ }^{219}$ Of these, the Zimmer Durom Hip Cup settlement is noteworthy, for the judge not only ordered all plaintiffs' attorneys to register all of their clients, but also ordered all plaintiffs to participate in the settlement and stayed the proceedings

ment Agreement § 5.02, In re Actos (Pioglitazone) Prods. Liab. Litig., No. 11-md2299 (W.D. La. Apr. 28, 2015) [hereinafter Actos Settlement].

210 Settlement Agreement Between Biomet, Inc. and Plaintiffs Executive Committee भIII 2, 3, 5, In re Biomet M2A Mangum Hip Implant Prods. Liab. Litig., No. 12-md-2391 (N.D. Ind. Jan. 31, 2014).

211 E.g., In re Actos (Pioglitazone) Prods. Liab. Litig., No. 6:11-md-2299 (W.D. La. Apr. 28, 2015) (order regarding settlement agreement and deadlines); In re NuvaRing Prods. Liab. Litig., No. 08-md-1964 (E.D. Mo. Jan. 29, 2014) (case management order of January 29, 2014 (supplemental census of claims)); In re Yasmin and Yaz (Dropirenone) Mktg., Sales Pract. Prods. Liab. Litig.), No. 3:09md-02100 (S.D. Ill. Aug. 3, 2015) (case management order no. 77 (census of claims)).

212 E.g., In re Actos (Pioglitazone) Prods. Liab. Litig., No. 11-md-2299 (W.D. La. Apr. 28, 2015) (order regarding settlement agreement and deadlines); Actos Settlement, supra note 209, § 1.02 .

213 Vioxx Settlement, supra note 200, at $1 \mathrm{I} 1.1$.

2142013 DePuy Settlement, supra note 203, at art. 3, §§ 3.1-3.3; 2015 DePuy

Settlement, supra note 203, at art. 3, §§ 3.1-3.3.

215 Yaz ATE Settlement, supra note 205, § 1.02.

216 Actos Settlement, supra note 209, § 1.02.

217 NuvaRing Settlement, supra note 209, § 1.05.

218 Zimmer Durom Settlement, supra note 208, § I.B.

219 NuvaRing Settlement, supra note 209, § 1.05. 
pending the conclusion of the settlement's mediation process. ${ }^{220}$

The attorney recommendation and attorney withdrawal provisions from Propulsid were also common across the settlements in our database, with some form of recommendation included in all but the Zimmer Durom Hip Cup and Biomet settlements, and explicit, mandatory attorney-withdrawal provisions in Vioxx, ${ }^{221}$ Fosamax, ${ }^{222}$ and American Medical Systems. $^{223}$ As in Propulsid, the recommendation and withdrawal provisions in these three proceedings worked in concert to require an attorney who had a single client who wanted to accept the settlement offer-whether in the multidistrict proceeding or state court-to recommend that all of her clients accept the deal. If a client refused to do so, the attorney had to withdraw from representing her. Essentially, these provisions tie the attorneys' desire to be paid for their services to the defendant's desire for closure. After Vioxx, commentators frequently discussed and criticized that link, ${ }^{224}$ which may have prompted settlement designers in Actos, NuvaRing, and Yasmin/Yaz to require only that the lead lawyers "use their best efforts to achieve sufficient participation to meet the participation benchmarks necessary to effectuate the Program." 225 The Yasmin/Yaz gallbladder settlement, however, contained an additional provision that automatically enrolled the plaintiffs in the settlement and required them to either affirmatively opt-out of

220 In re Zimmer Durom Hip Cup Prods. Liab. Litig., No. 09-cv-04414, IIII 1-3 (D.N.J. May 13, 2016) (case management order regarding settlement agreement). 221 Vioxx Settlement, supra note 200, § 1.2.8.1. After some plaintiffs' attorneys contended the settlement conflicted with ethical rules, it was reinterpreted to mean that the attorneys should recommend the deal only if it was in the client's best interest. See Alex Berenson, Some Lawyers Seek Changes in Vioxx Settlement, N.Y. TIMES, Dec. 21, 2007; see also In re Vioxx Prods. Liab. Litig., 388 Fed. Appx. 391, 395-97 (5th Cir. July 16, 2010) (affirming district court judge's handling of non-settling plaintiffs).

222 Fosamax Settlement, supra note 200, IIII 1-2, 5 \& Ex. C at C-15 (certification and joinder of counsel, claimant's counsel). The court subsequently granted numerous' attorneys motions to withdraw from representing non-settling claimants. E.g., In re Fosamax Prods. Liab. Litig., 06-md-1789 (S.D.N.Y. Sept. 22, 2014) (order allowing Levin, Papantonio, Thomas, Mitchell, Rafferty \& Proctor, P.A. to withdraw as counsel).

223 Even if 95\% of the claimants took the offer, the agreement still required counsel to "employ their best efforts to obtain an executed Release from 100\%," and if a client refused those overtures, counsel had to withdraw from representing that client. American Medical Systems Settlement, supra note 207, §§ II.H-I.

224 E.g., Howard M. Erichson \& Benjamin C. Zipursky, Consent Versus Closure, 96 CORNELL L. REV. 265, 266-68 (2011).

225 Each settlement uses this identical language. Yaz Gallbladder Settlement, supra note 204, § 9.01; Yaz ATE Settlement, supra note 205, § 3.01; Actos Settlement, supra note 209, § 5.01; NuvaRing Settlement, supra note 209, § 10.01. 
the arrangement (even though it was not a class action) or submit a claim package before the deadline. ${ }^{226}$

The two DePuy ASR settlements varied slightly in their recommendation and withdrawal provisions. Individual signatory attorneys-not just lead lawyers-had to "represent and warrant that they each will use their best efforts to secure all documentation required for timely enrollment and compliance with this Agreement," 227 and, subject to their professional judgment, "endorse enrollment in the U.S. Program to clients covered by this Agreement."228 Instead of requiring plaintiffs' counsel to withdraw from representing those clients who preferred not to settle, the Special Master could determine that a law firm or interested counsel "did not act in good faith in connection with the informed consent process and participation," 229 and DePuy, "at its sole option," could expel that firm's or that attorney's other clients from the settlement. ${ }^{230}$

In sum, Figure 8 below illustrates how highly connected repeat players have replicated and advanced Propulsid's closure provisions, presumably in response to feedback and deficiencies they perceived in prior settlements. Propulsid may well have been a tipping point in handling nonclass litigation. But, because it is the earliest available nonclass settlement in our data, we cannot be certain. Generally speaking, tipping points occur when innovations take off in a network, as it seems that Propulsid's closure provisions did. ${ }^{231}$ And it appears that repeat players in our network used their connections to diffuse and perfect settlement practices originating from Propulsid. ${ }^{232}$ As such, well-connected attorneys may not only lead litigations, they may also occupy roles as influential opinion leaders; individuals who are central to a network and rank highly on betweenness measures can be especially effective at transmitting and diffusing new ideas and practices. ${ }^{233}$

226 Yaz Gallbladder Settlement, supra note 204, § 1.01(A); In re Yasmin and Yaz (Dropirenone) Mktg., Sales Pract. Prods. Liab. Litig., No. 09-md-2100 (S.D. Ill. Mar. 15, 2013) (case management order no. 60 at 2).

2272015 DePuy Settlement, supra note 203, § 17.2.8; 2013 DePuy Settlement, supra note 203, § 17.2.8.

2282015 DePuy Settlement, supra note 203, § 17.2.8; 2013 DePuy Settlement, supra note 203 , § 17.2.8.

2292015 DePuy Settlement, supra note 203, § 17.2.12; 2013 DePuy Settlement, supra note 203, § 17.2.12.

2302015 DePuy Settlement, supra note 203, § 17.2.12; 2013 DePuy Settlement, supra note 203, § 17.2.12.

231 See KADUSHIN, supra note 19, at 136-43, 187.

232 Diffusion is a familiar concept-most people have caught colds (contagion) or picked up ideas from others (diffusion). KADUSHIN, supra note 19, at 135-36.

233 Id. at 145. 
Figure 8: The Evolution of Closure Provisions Stemming FROM PROPULSID

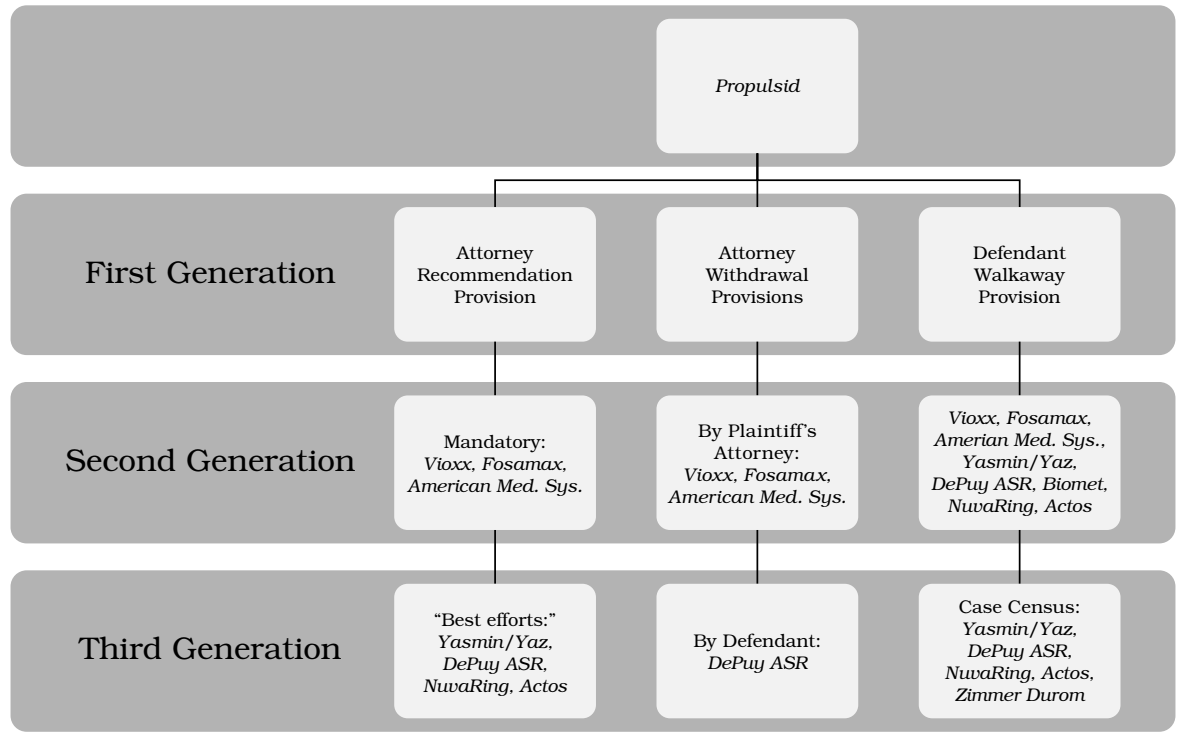

\section{Common-Benefit Fee Awards}

One such practice has evolved with regard to enhancing leaders' common-benefit fees. Transferee judges often issue an order at the beginning of litigation that establishes a commonbenefit fund to pay lead lawyers for their fees and costs by taxing the individual attorneys and their clients a specific percentage of clients' gross settlement proceeds. ${ }^{234}$ While judges have cited various rationales for their authority, ${ }^{235}$ the orders essentially create a take-it-or-leave-it proposition, where "leaving it" means referring clients to someone else or, if possible, filing suit in state court where individual attorneys may nevertheless have to contribute if their clients want to participate in a global settlement that federal leadership negotiates. While lead lawyers with clients will have to contribute to the fund too, their money will eventually transfer from one pocket to the other at the same rate, unless the judge awards that leader less of a common-benefit fee. Our analysis of the settlements and attorneys' fees found not only that common-benefit fees are typically awarded, but that they are frequently increased during the litigation when leaders request a judicially awarded raise, negotiate some aspect of their fees with the defendant

234 See Dubay, supra note 59, at 45-46; William B. Rubenstein, On What a "Common Benefit Fee" Is, Is Not, and Should Be, Class Action ATtORneY's FeE DiGEST, Mar. 2009, at 87-89.

235 Burch, supra note 20, at 102-09. 
through settlement design, or use some combination of the two.

TABle 8: COMmon-Benefit FeEs

\begin{tabular}{|c|c|c|c|c|c|}
\hline \multicolumn{3}{|c|}{ MDL Information } & \multicolumn{3}{|c|}{ Common-Benefit Fees } \\
\hline 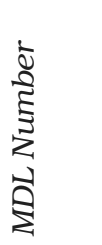 & 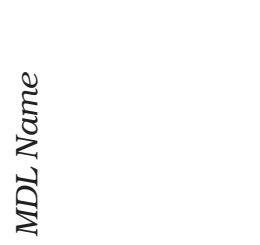 & 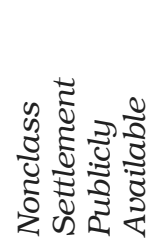 & 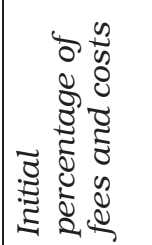 & 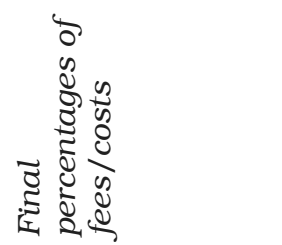 & 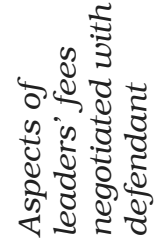 \\
\hline 1355 & Propulsid & Yes, both & $6 \%$ & $6 \%$ & Yes \\
\hline 1657 & Vioxx & Yes & $\begin{array}{l}3 \% \\
(2 / 1)\end{array}$ & $6.5 \%$ & Yes \\
\hline 1789 & Fosamax & Yes & $9 \%$ & $9 \%$ & Yes \\
\hline 1964 & NuvaRing & Yes & $\begin{array}{l}8 \% \\
(5 / 3)\end{array}$ & $15.5 \%(11 / 4.5)$ & No \\
\hline 2100 & $\begin{array}{l}\text { Yasmin and Yaz } \\
\text { (Drospirenone) }\end{array}$ & Yes, both & $\begin{array}{l}6 \% \\
(4 / 2)\end{array}$ & $\begin{array}{l}11 \% \\
(9 / 2) \text { for ATE; } \\
6 \% \\
(4 / 2) \text { for } \\
\text { gallbladder }\end{array}$ & Yes \\
\hline 2158 & $\begin{array}{l}\text { Zimmer Durom } \\
\text { Hip Cup }\end{array}$ & Yes & \begin{tabular}{|l}
$4 \%$ \\
$(2 / 2)$ \\
Federal \\
plaintiffs \\
only
\end{tabular} & $\begin{array}{l}4 \% \\
(2 / 2) \\
\text { State and federal } \\
\text { plaintiffs }\end{array}$ & Yes \\
\hline 2197 & $\begin{array}{l}\text { DePuy ASR Hip } \\
\text { Implant }\end{array}$ & Yes, both & $\begin{array}{l}4 \% \\
(3 / 1)\end{array}$ & $\begin{array}{l}6 \% \\
(5 / 1)\end{array}$ & Yes \\
\hline 2325 & $\begin{array}{l}\text { American } \\
\text { Medical } \\
\text { Systems }\end{array}$ & Semi & $5 \%$ & $5 \%$ & $\begin{array}{l}\text { Not } \\
\text { available }\end{array}$ \\
\hline 2391 & $\begin{array}{l}\text { Biomet } \\
\text { Magnum Hip } \\
\text { Implant }\end{array}$ & Yes & $\begin{array}{l}6 \% \\
(5 / 1)\end{array}$ & $3.99 \%$ & Yes \\
\hline 2299 & $\begin{array}{l}\text { Actos } \\
\text { (Pioglitazone) }\end{array}$ & Yes & None set & $8.6 \%$ & Yes \\
\hline
\end{tabular}

Midstream fee increases took a variety of forms. In DePuy $A S R$, the court initially assessed a 3\% common-benefit fee plus $1 \%$ for costs. ${ }^{236}$ But after the plaintiffs' steering committee negotiated a settlement that required each plaintiff who settled-whether in federal or state court-to consent to the transferee court's fee order, it then requested that the court md-2197 (N.D. Ohio 2011) (case management order no. 13 at 5). 
increase fees from 3 to $5 \%$, leaving $1 \%$ for costs intact. ${ }^{237}$ No one objected, and the court made the change. ${ }^{238}$ Similarly, in the Yasmin/Yaz litigation, a request from the lead lawyers increased the assessments from 4 to $9 \%,{ }^{239}$ with the court noting that no one opposed the motion and that the increase received "unanimous consent by the PSC."240 Unlike DePuy and Yaz, one attorney in the NuvaRing litigation did object to fees, but only as to his own payout as a steering committee member. ${ }^{241}$ Yet, the NuvaRing plaintiffs' steering committee was united in asking the court to raise its common-benefit assessment from $5 \%$ fees and $3 \%$ costs to $11 \%$ for attorneys' fees (to be subtracted from primary counsel's fees) and $4.5 \%$ for costs (subtracted from clients' settlement amount). ${ }^{242}$

Not only did plaintiffs' leadership request and receive fee increases midstream, but in three of the examined settlements lead lawyers negotiated their payment directly with the defendant. That practice first appeared in the tobacco litigation ${ }^{243}$ and continues now, appearing in both Propulsid settlements, and in the Biomet settlement. In the first and second Propulsid settlements, lead lawyers negotiated a \$22.5 million fee ${ }^{244}$ and a $\$ 4$ million fee, ${ }^{245}$ respectively. The court later authorized

2372013 DePuy Settlement, supra note 203, § 4.1.8; Plaintiffs' Steering Committee's Motion to Modify the Common Benefit Attorney Fee Hold Back to 5\% of the Gross Recovery Amount at 1, In re DePuy Orthopaedics, Inc. ASR Hip Implant Prods. Liab. Litig., No. 10-md-2197 (N.D. Ohio Feb. 12, 2014).

238 In re DePuy Orthopaedics, Inc. ASR Hip Implant Prods. Liab. Litig., No. 10md-2197 (N.D. Ohio Mar. 3, 2014) (order).

239 Plaintiffs' Steering Committee's Motion to Modify Case Management Order No. 14 at 1-2, In re Yasmin and Yaz (Dropirenone) Mktg., Sales Pract. Prods. Liab. Litig., No. 09-md-2100, (S.D. Ill. Apr., 23, 2014).

240 In re Yasmin and Yaz (Dropirenone) Mktg., Sales Pract. Prods. Liab. Litig., No. 3:09-md-2100 (S.D. Ill. May 16, 2014) (order granting 3315 motion for relief); In re Yasmin and Yaz (Dropirenone) Mktg., Sales Pract. Prods. Liab. Litig., No. 09md-2100 (S.D. Ill. June 23, 2014) (case management order 63 supplement to case management order no. 14).

241 Ferrer, Piorot \& Wansbrough's Objections to Special Master's Recommendation for Common Benefit Attorneys' Fees at 1-3, In re NuvaRing Prods. Liab. Litig., No. 08-md-1964 (E.D. Mo. Sept. 2, 2014).

242 In re NuvaRing Prods. Liab. Litig., No. 08-md-1964 (E.D. Mo. Dec. 9, 2009) (case management order no. 3); Motion to Amend Case Management Order No. 3 at 2-7, In re NuvaRing Prods. Liab. Litig., No. 08-md-1964 (E.D. Mo. Dec. 7, 2011); In re NuvaRing Prods. Liab. Litig., No. 08-md-1964 (E.D. Mo. Dec. 9, 2011 ) (amended case management order no. 3).

243 See Lester Brickman, Contingency-Fee Con Men, Wall St. J., Sept. 25, 2007, at A18 (describing how private attorneys "worked out a side deal with the tobacco industry for the latter to separately pay them fees well in excess of \$15 billion").

244 First Propulsid Settlement, supra note 178, § 19.

245 Second MDL Program Term Sheet § 19, In re Propulsid Prods. Liab. Litig., No. 00-md-1355 (E.D. La. Dec. 15, 2005). 
these amounts through its award, 246 and then added $\$ 397,860.00$ based on the $6 \%$ common-benefit fund it installed at the litigation's outset. ${ }^{247}$

Biomet is likewise interesting as it was the only settlement to feature a choice for those on the Plaintiffs' Steering Committee. Lead lawyers negotiated a $\$ 6$ million fee directly with the defendant via a separate agreement-contingent, of course, on fulfilling the participation percentages necessary to effectuate the master settlement agreement-as well as a 5\% attorneys' fee assessment (with an additional $1 \%$ for costs). ${ }^{248}$ But the court's order required them to accept the lesser of the two-not both. ${ }^{249}$ Leaders took the fee they negotiated directly with the defendant, which was likely far more profitable for them: it appears that lead lawyers represented the bulk of the clients (the court needed a new steering committee post-settlement since most members settled all their clients' claims), ${ }^{250}$ so the defendant may have compensated the steering committee for work they were already required to perform under their initial contingent-fee agreement. Put differently, lead lawyers likely received their full contingent fees plus a $\$ 6$ million bonus from defendants. ${ }^{251}$

Sometimes, even when lead lawyers negotiate aspects of their fees directly with the defendant, those fees come out of other plaintiffs' attorneys' fees. By inserting fee provisions into a master settlement such that claimants (and their counsel) who want to settle must also "consent" to leadership's heightened fee, lead attorneys can reach settling state-court plaintiffs

246 In re Propulsid Prods. Liab. Litig., No. 00-md-1355 (E.D. La. Aug. 22, 2012) (order); In re Propulsid Prods. Liab. Litig., No. 00-md-1355 (E.D. La. June 2, 2005) (order).

247 Plaintiffs' Liaison Counsel's Memorandum in Support of Motion for Final Distribution of Remaining Funds at 3-4, In re Propulsid Prods. Liab. Litig., No. 00md-1355 (E.D. La. Jan. 31, 2014); In re Propulsid Prods. Liab. Litig., No. 00-md1355 (E.D. La. Feb. 3, 2014) (order).

248 Motion for Payment of Common Benefit Attorneys' Fees and Expenses from the Biomet Common Benefit MDL Assessment Fund § 7, In re Biomet M2A Mangum Hip Implant Prods. Liab. Litig., No. 12-md-2391 (N.D. Ind. Aug. 7, 2015) ("Pursuant to a separately negotiated settlement agreement dated January 31, 2014, the Biomet Common Benefit Settlement Agreement (CBSA), Biomet will deposit an additional \$6 million into the Biomet Common Benefit Attorney's Fee Fund for the sole purpose of resolving the Common Benefit Attorney Fees associated with this litigation.").

249 In re Biomet M2A Mangum Hip Implant Prods. Liab. Litig. § II.B.2(c), No. 12-md-2391 (N.D. Ind. Feb. 3, 2014) (case management order establishing common benefit fee and expense funds § $2(\mathrm{c}))$.

250 In re Biomet M2A Mangum Hip Implant Prods. Liab. Litig., No. 12-md-2391 (N.D. Ind. Apr. 28, 2015) (order).

251 See supra note 248 (noting the $\$ 6$ million fee). 
who would otherwise fall outside of the transferee judge's jurisdiction. In Actos and Fosamax, lead lawyers included a provision that subjected all settling plaintiffs-including those pending in state courts-to the transferee judge's fee assessment. ${ }^{252}$ And, in Fosamax, if a lawyer waited until settlement to agree to the common-benefit tax (as many state-court attorneys would) then the court's common-benefit fund order increased the assessment from 6 to $9 \% .{ }^{253}$ Lead lawyers in Vioxx went one step further: they contracted around the court's 3\% fee cap, raised it to $8 \%$, and deducted the entire amount from individual attorneys' contingent fees. ${ }^{254}$ Yet, unlike many of the cases examined, the carte blanche revision incited numerous objections. ${ }^{255}$ Accordingly, the judge appointed a liaison counsel, who oversaw status conferences, discovery, briefing, and arguments; eventually lead lawyers agreed to reduce their fee request to $7.5 \% .{ }^{256}$ Nevertheless, the judge reduced the award to $6.5 \%$, or $\$ 315,250,000$ in fees-still a notable difference from the initial $3 \% .^{257}$

Zimmer Durom Hip Cup was notable for initially deviating from this pattern, but then following it. The judge's original common-benefit order included a $4 \%$ fee, permitted the court to adjust that percentage based on factors in the Model Rules of Professional Conduct, and expressly struck language that taxed state-court litigants. ${ }^{258}$ After the court repeatedly reduced common-benefit holdbacks in individual cases, ${ }^{259}$ the lead lawyers asked for a new order applying the holdback to all state-court plaintiffs who benefitted from their efforts. ${ }^{260}$ Citing both a lack of jurisdiction for doing so and noting that

252 Actos Settlement, supra note 209, § 10.04; Fosamax Settlement, supra note 201 , Tा 14.

253 In re Fosamax Prods. Liab. Litig., No. 06-md-1789, §§ 3-4 (S.D.N.Y. Jan. 5, 2010) (case management order no. 17).

254 Vioxx Settlement, supra note 200, § 9.2.1.

255 In re Vioxx Prods. Liab. Litig., 760 F. Supp. 2d 640, 646-47 (E.D. La. 2010); Charles Silver, The Responsibilities of Lead Lawyers and Judges in Multidistrict Litigation, 79 FORDHAM L. REV. 1985, 2001-02 (2011).

256 Vioxx, 760 F. Supp. 2d at 646-47.

257 Id. at $655,658$.

258 Case Management Order No. 3: Order Establishing Common Benefit Fund, IIII 3, 11, In re Zimmer Durom Hip Cup Prods. Liab. Litig., No. 09-cv-04414 (D.N.J. Jan. 21, 2011).

259 E.g., In re Zimmer Durom Hip Cup Prods. Liab. Litig., No. 09-cv-04414 (D.N.J. Dec. 22, 2011) (order reducing common-benefit contribution to 1\%); In re Zimmer Durom Hip Cup Prods. Liab. Litig., No. 09-cv-04414 (D.N.J. June 8, 2011) (same).

260 Plaintiffs' Motion to Modify Case Management Order No. 3 to Provide for Contribution to the Common Benefit Fund by State-Court Plaintiffs, In re Zimmer Durom Hip Cup Prods. Liab. Litig., No. 09-cv-04414 (D.N.J. Jan. 26, 2015). 
leaders had not conferred benefits on the state plaintiffs, the court refused. ${ }^{261}$ Nevertheless, when leaders negotiated a master settlement, they included a provision that unilaterally taxed all settling plaintiffs $4 \% .{ }^{262}$ The court then ordered all multidistrict plaintiffs to participate in the settlement, comply with its deadlines, or face dismissal. ${ }^{263}$ Because the settlement required all participating lawyers to register all their cases (filed or unfiled, in state or federal court), ${ }^{264}$ lead lawyers effectively used their bargaining authority with the defendant to expand the federal court's jurisdiction and their fee base.

Additionally, we observed a common practice of scaling up fee assessments based on how quickly individual counsel assented to common-benefit fees. The Fosamax fee request and order, for example, offered 3\% fees and 3\% costs for those who consented (whether in federal or state court) to the assessment agreement within 90 days, but increased the price to $5 \%$ fees and 3\% costs for latecomers; if an attorney waited to see whether the lead lawyers actually negotiated a beneficial deal for their clients, then fees and costs increased to 6 and 5, respectively. ${ }^{265}$ Likewise, the Yasmin/Yaz litigation assessed $6 \%$ initially, and $10 \%$ for latecomers. ${ }^{266}$ Plainly, the point is to incentivize early buy-in from the individual attorneys whose contingency fees will be reduced even though the increase may not align with quantum-meruit principles. ${ }^{267}$

\section{Latecomer Reductions and Reversion Clauses}

Finally, we observed two provisions that, while not as common as others, warrant increased scrutiny-latecomer reductions and reversion provisions. Settlement designers in DePuy ASR and Zimmer Durom Hip Cup experimented with a unique clause that reduced payouts to claimants who were not repre-

261 In re Zimmer Durom Hip Cup Prods. Liab. Litig., No. 09-cv-04414 (D.N.J. Apr. 30, 2015) (order on motion to modify CMO No. 3).

262 Zimmer Durom Settlement, supra note 208, § V.C.

263 In re Zimmer Durom Hip Cup Prods. Liab. Litig., No. 09-cv-04414, II 2 (D.N.J. May 13, 2016) (case management order regarding settlement agreement).

264 Zimmer Durom Settlement, supra note 208, § I.B.

265 Plaintiffs' Steering Committee's Memorandum of Authorities in Support of Motion for Creation of a Common Benefit Fund at 11, In re Fosamax Prods. Liab. Litig., No. 1:06-md-1789 (S.D.N.Y. Oct. 21, 2009) (requesting a 10\% total assessment for those who waited until settlement); In re Fosamax Prods. Liab. Litig., No. 1:06-md-1789 (S.D.N.Y. Jan. 5, 2010) (case management order no. 17 at 3-4).

266 In re Yasmin and Yaz (Drospirenone) Mktg. Sales Practices \& Prods. Liab. Litig., No. 09-md-2100, §§ 3-4 (S.D. Ill. Mar. 25, 2010) (case management order no. 14 (establishing common benefit fee and expense fund) at 3-4).

267 Burch, supra note 20, at 128-35. 
sented by counsel as of a certain date. ${ }^{268}$ The idea was to thwart the Field-of-Dreams problem for the defendant: creating a claims process can encourage attorneys and plaintiffs (often with weaker claims) to emerge at the last minute, file suit, and partake of the settlement.

To discourage this, latecomer provisions immediately reduced unrepresented claimants' awards by $29 \%$ and covered two groups of people: (1) those litigating pro se, and (2) those who retained attorneys and filed suit after the identified date. As to the former, DePuy ASR designers claimed that the reduction simply discounted pro se litigants' payout to the same amount they would have received if they had to pay attorneys' fees, but noted, "there will be an additional Court approved deduction for common benefit fees and expenses."269 The second group with counsel is even worse off, for they began with 29\% less than those who retained counsel before the date and will then have to pay their primary counsel's fees and commonbenefit fees out of that reduced award. ${ }^{270}$ These latecomer provisions help defendants by encouraging attorneys to file all of their pending cases immediately and by discouraging further attorney advertising. Plus, the provisions are mostly costless for lead lawyers who have advanced notice of the provision, can file all of their claims, and, in DePuy ASR's case, still receive latecomers' common-benefit fees.

In addition to the latecomer reductions, both DePuy ASR settlements contained reversion clauses: the 29\% taken off the top of unrepresented plaintiffs' claims reverted to DePuy, the defendant. ${ }^{271}$ Propulsid made even greater use of reversion clauses, initially reverting $\$ 40$ million of an $\$ 87$ million fund to defendant Johnson \& Johnson, 272 then $\$ 5$ million of the sec-

2682013 DePuy Settlement, supra note 203, § 4.4; 2015 DePuy Settlement, supra note 203, § 4.4; Zimmer Durom Settlement, supra note 208, § II.A.2.e.

269 ASR Settlement - Benefits Overview at 4, In re DePuy Orthopaedics, Inc. ASR Hip Implant Prods. Liab. Litig., No. 10-md-2197 (N.D. Ohio Mar. 20, 2015) [https://perma.cc/5FXT-ZZDH]; see also Zimmer Durom Settlement, supra note 208, § V.C. (reducing common-benefit fees for unrepresented claimants to $2 \%)$.

270 For an ethical analysis of this practice, see Burch, Monopolies, supra note 71 , at $104-07$.

2712013 DePuy Settlement, supra note 203, §§ 7.1.3.1, 7.1.7; 2015 DePuy Settlement, supra note 203, §§ 7.1.3.1, 7.1.7.

272 Joint Motion and Order for Partial Disbursement of Settlement Funds to Defendant Johnson \& Johnson, In re Propulsid Prods. Liab. Litig., No. 00-md1355 (E.D. La. Dec. 14, 2011); In re Propulsid Prods. Liab. Litig., No. 00-md-1355 (E.D. La. Dec. 19, 2011) (order). 
ond \$15 million fund, 273 and finally the remaining balance of all settlement and administrative funds. ${ }^{274}$ In class actions, reversion clauses have triggered additional scrutiny to determine whether the settlement's terms were detrimental to the class. ${ }^{275}$ Absent the class device, courts lack the formal authority to oversee aggregate settlements, though they retain the power to award common-benefit fees under quantum-meruit principles. ${ }^{276}$

\section{IV \\ IMPLICATIONS}

Nonclass aggregation has long fostered an uneasy union between the individual and the collective. This tension plays out among scholars, as they consistently prioritize one over the other: some want to use aggregation procedures to regulate conduct efficiently and deter wrongdoing in order to maximize social welfare, while others privilege individual autonomy and consent over the general welfare, aiming to afford individual justice to victims through their own day in court. ${ }^{277}$ While

273 In re Propulsid Prods. Liab. Litig., No. 00-md-1355 (E.D. La. Dec. 19, 2011) (order).

274 In re Propulsid Prods. Liab. Litig., No. 00-md-1355 (E.D. La. Oct. 3, 2012) (order terminating the claims of all enrollees in the second MDL resolution program and authorizing return to the defendants the balance of the settlement fund and administrative fund after all payments due thereunder have been made).

275 Int'l Precious Metals Corp. v. Walters, 530 U.S. 1223, 1223 (2000) (O'Connor, J., statement respecting the denial of the petition for a writ of certiorari); In re Bluetooth Headset Prods. Liab. Litig., 654 F.3d 935, 947-48 (9th Cir. 2011).

276 Burch, supra note 20, at 116-18, 128-38.

277 For examples of those who tend to emphasize individual autonomy, see Richard A. Epstein, The Consolidation of Complex Litigation, 10 J. L. \& CoM. 1, 32-33 (1990); Martin H. Redish \& Nathan D. Larsen, Class Actions, Litigant Autonomy, and the Foundations of Procedural Due Process, 95 CAL. L. REV. 1573, 1573-75 (2007). Echoes of autonomy exist in Supreme Court opinions as well. E.g., Ortiz v. Fibreboard Corp., 527 U.S. 815, 846 (1999); Martin v. Wilks, 490 U.S. 755, 762 (1989) (discussing the idea of one's own day in court). For examples of those adopting a collective or efficiency-based approach, see Bruce L. Hay, Asymmetric Rewards: Why Class Actions (May) Settle for Too Little, 48 HASTINGS L.J. 479, 479-84 (1997); David Rosenberg, Class Actions for Mass Torts: Doing Individual Justice by Collective Means, 62 InD. L.J. 561, 561-68 (1987); David Rosenberg, Individual Justice and Collectivizing Risk-Based Claims in Mass Exposure Cases, 71 N.Y.U. L. REV. 210, 210-16 (1996). Still others have recommendations for mitigating between these two camps to protect both individual and group interests. See, e.g., Edward H. Cooper, Rule 23: Challenges to the Rulemaking Process, 71 N.Y.U. L. REV. 13, 26-32 (1996); Richard L. Marcus, They Can't Do That, Can They? Tort Reform via Rule 23, 80 CoRNELL L. REV. 858, 858-59 (1994); Francis E. McGovern, An Analysis of Mass Torts for Judges, 73 TEX. L. REV. 1821 , 1821-22 (1995); Judith Resnik, Aggregation, Settlement, and Dismay, 80 CORNELL L. REV. 918, 918-22 (1995). Some of these demarcations come from David L. 
social networks do not ease this fundamental tension, they do allow us to consider both individuals and groups-to understand how interconnections and interactions among people and events affect attorneys' fees and claims resolution, and how those fees and results may impact individuals' perceptions about the justice system.

Mapping the network of attorneys and proceedings and then analyzing the deals that repeat players design provides us with some insight into the flow of information between connected repeat players, the replication and refinement of practices, and how well-connected leaders might use their positional influence within the network to create, disseminate, and perpetuate norms and practices that benefit their working relationships. As past work considered how these cases compared with non-aggregated litigation and how they proceeded through federal courts, ${ }^{278}$ the next logical step was to examine who shepherded these cases through the legal system and how they resolved them without Rule 23's protections. Accordingly, this Article considered who the repeat lawyers are in a sample of products-liability and sales-practices proceedings, the connections between them, the nonclass settlements they designed, and the common-benefit fees they received.

Consistent with past findings, repeat players do exist, and they serve in leadership positions that allow them to negotiate master settlements. As we elaborate in this Part, those positions likewise afford them influence. And their connectedness in the network may allow them to diffuse, adapt, and replicate practices that benefitted them financially. ${ }^{279}$ Consequently,

Shapiro, Class Actions: The Class as Party and Client, 73 NOTRE DAME L. REv. 913, 914-16 n.3-4 (1998).

278 Catherine R. Borden, Emery G. Lee III \& Margaret S. Williams, Centripetal Forces: Multidistrict Litigation and Its Parts, 75 LA. L. REv. 425, 425-27 (2014).

279 For example, Duke Law Center for Judicial Studies appointed an editorial board of six attorneys to create a "MDL Standards and Best Practices" guide. Each board member is a high-level repeat player. Chilton Varner, of King \& Spalding, is a defense attorney who litigated Fosamax and Paxil. John Beisner, of Skadden Arps, is a defense attorney who litigated Vioxx and DePuy ASR and his law firm appeared seven times on the defense side in the data. Elizabeth Cabraser, of Lieff Cabraser Heimann \& Bernstein, is a plaintiffs' attorney who was appointed as a lead lawyer six times and lawyers for her firm were appointed a total of seventeen times. Christopher Seeger, of Seeger Weiss LLP, is a plaintiffs' attorneys who was appointed as a lead lawyer fourteen times in the data and lawyers from his firm were appointed a total of twenty times. Ted Mayer, of Hughes Hubbard \& Reed, is a defense attorney who litigated Fosamax and Vioxx. Daniel Girard, of Girard Gibbs, did not appear in the data since the focus was on products-liability cases and he specializes in securities suits, but his law firm appeared on the defense team of seven product-liability cases. See also Tables 3-4, A2-A3, supra at 34-36, infra at 72-74 (listing repeat players). 
this Part begins by discussing our findings on repeat players' impact, then postulates that these repetitive interactions could add to classic principal-agent problems by desensitizing lawyers to behavior that benefits counsel more than clients. We then situate multidistrict litigation within the rich literature on other complex adaptive systems and use those core insights to suggest that future reformers would do well to consider how network connectivity affects their efforts to provoke systemic change.

\section{A. Repeat Players' Impact}

To begin to gauge repeat players' impact, we obtained and analyzed the thirteen publicly available, private nonclass settlements that occurred in ten multidistrict litigations within our dataset, which collectively covered 64,107 actions. In examining those settlements, we looked for four types of provisions: (1) those that generate closure (attorneyrecommendation, attorney-withdrawal, walkaway, and casecensus provisions); (2) those where lead lawyers negotiate some aspect of their fees with a defendant either directly or through the settlement; (3) those that reduced awards to latecomers; and (4) those that allowed the money remaining in the settlement fund to revert to defendants. Closure, latecomer, and reversion provisions benefit defendants, while common-benefit fee provisions reward lead plaintiffs' lawyers. When courts and the parties made the claims-filing data public, which was rare, we considered that information as well. ${ }^{280}$

As evidenced previously in Table 6, we found that at least one of our top five repeat players (based on degree centrality) participated directly in each settled litigation's leadership. The Propulsid settlement designers noted they were creating a template for settlement, and they were correct. Every nonclass settlement in our database after it contained some of its features and at least one closure-related provision to help end the lawsuits.

280 For an overview of what little information was available, see Burch, Monopolies, supra note 71 , at 131-32, Table 3 . 
Figure 9: SUMMARY OF PROVISIONS IN THE THIRTEEN EXAMINED SETTLEMENTS

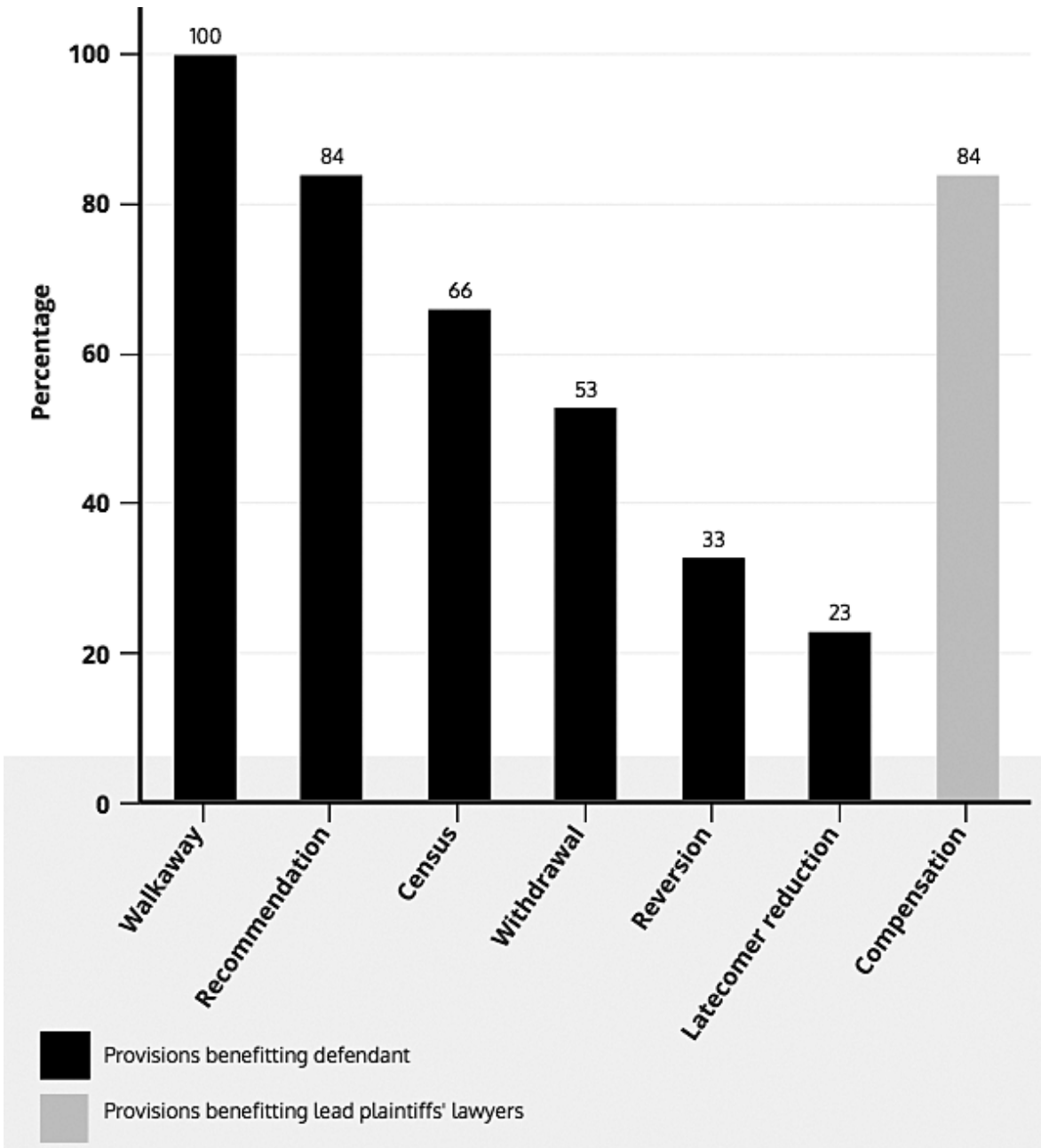

Each settlement uniformly departed from conventional deals between plaintiffs and defendants, shifting the deal-making entities to lead lawyers and defendants, and then requiring individual attorneys to either become additional signatories or recommend the deal to all of their clients if one client wanted to settle. Additionally, as Figure 9 illustrates, every settlement permitted the defendant to walk away from its funding obligations if too few claimants abandoned their right to sue in the judicial system in favor of the settlement's claims-administration process. Combined, these changes tied plaintiffs' attorneys' financial self-interest to each other, for none of them would receive fees if too few claimants accepted the settlement offer. Also like Propulsid, two settlements took the added step 
of explicitly requiring attorneys to withdraw from representing clients who refused to settle.

Common-benefit fee and settlement-fund distribution practices were remarkably similar, with plaintiffs' leadership often negotiating a fee increase for themselves at the end of a proceeding. Moreover, in two of the eleven litigations, Propulsid and Biomet, lead lawyers negotiated their fees directly with the defendant, such that the fees were not apportioned from the common fund (in accordance with a restitution theory), ${ }^{281}$ but from the defendant's coffers. In six other litigations-Vioxx, Yasmin/Yaz, DePuy ASR, Fosamax, Actos, and Zimmer Durom Hip Cup-lead lawyers included some aspect of their commonbenefit fee within the settlement, which meant negotiating their compensation with the defendant. Bargaining over attorneys' fees with one's opponent-even if subject to court approval-is a unilateral move away from contingent fees, which are designed to tie the fates of lawyer and client by increasing fees in proportion with a client's actual recovery.

Finally, both DePuy ASR settlements and the Zimmer Durom Hip Cup settlement contained latecomer reductions, which help defendants by discouraging attorney advertising and reducing payouts. And two litigations (each producing two settlements)-Propulsid and DePuy ASR-included provisions in which all or part of the remaining settlement funds reverted to the defendants. In DePuy ASR, the reversion clause worked in concert with the settlement's practice of reducing payouts to latecomers since those funds reverted to the defendant.

In sum, we found robust empirical evidence of repeatplayer attorneys on both the plaintiff and defense side as well as a multidistrict-litigation leadership network that contains a strong, cohesive center. The lack of formal rules in multidistrict proceedings allows these repeat players to shape the methods for selecting and compensating leadership, and the lack of formal judicial oversight in nonclass settlements affords repeat players considerable latitude in settlement design.

Based on the limited nonclass settlements available to us, we found reason to be concerned that when repeat players influence the practices and norms that govern multidistrict proceedings-when they "play for rules," so to speak-the practices they develop, cite, and replicate may principally benefit them at one-shot plaintiffs' expense. While we were often

281 Charles Silver, A Restitutionary Theory of Attorneys' Fees in Class Actions, 76 CORNELL L. REV. 656, 663-66 (1991). 
unable to obtain claims-rate or payout information that was filed under seal or kept private, many of the settlement provisions appear to enrich lead plaintiffs' lawyers and the defendants with whom they broker the deal-not one-shot plaintiffs. ${ }^{282}$ If claims-administration data were available, it could provide a more complete and robust picture of the benefit these practices confer on claimants.

Given the data available to us, however, over a twenty-twoyear span, we were unable to find any publicly available nonclass settlement that did not feature at least one closure provision (which benefits the defendant). And, excepting NuvaRing, where the transferee court taxed settling state-court plaintiffs directly, ${ }^{283}$ and American Medical Systems, where fees were not available, each settlement likewise contained some provision that increased lead lawyers' fees. While one could argue that we cannot claim causation with such evidence (and to be fair, we are not trying to do so), the mere fact that the same players appear in the vast majority of these cases, resulting in remarkably similar settlements that benefit the people designing them merits concern and warrants further empirical investigation. ${ }^{284}$

\section{B. Implications for Leverage, Ethics, and Collusion}

A highly concentrated plaintiff and defense bar is nothing new, nor is the disquiet about where that concentration may lead. As scholars have long recognized, repeat play tends to regress our adversarial system from its confrontational roots toward a state of cooperation. ${ }^{285}$ In the criminal context, prosecutors and public defenders routinely work together through plea bargaining, leading them toward mutual accommodation; incumbents form a primary community of interest, whereas

282 Anecdotal evidence is rife with mistrust of the deals these lawyers create. See, e.g., Barry Meier, Frustration from a Deal on Flawed Hip Implants, N.Y. TIMES, Nov. 25, 2013, at B1 ("But some patients contend that the deal's real winners are Johnson \& Johnson and the plaintiffs' lawyers. Those lawyers are set to receive about one-third of the settlement, or about $\$ 800$ million. The single biggest chunk of those fees will go to the firms most involved with developing cases against Johnson \& Johnson and negotiating the settlement; they will get a bonus of about \$160 million.”).

283 Common Benefit Order at 3-4, In re NuvaRing Prods. Liab. Litig., No. 08md-1964 (E.D. Mo. Dec. 9, 2011).

284 See Jerome H. Skolnick, Social Control in the Adversary System, 11 J. CONFLICT RESOL. 52, 53 (1967) ("[A]s in all institutions based on conflict, there is a perception of 'deviance' when actors who are supposed to be genuinely antagonistic begin to cooperate.").

285 Id. at 68-69. 
clients present secondary challenges and contingencies. ${ }^{286}$ As such, adversary features are often overshadowed by regulars' quid pro quo needs. ${ }^{287}$ As Professor Jerome Skolnick has explained, those working group relationships become a social control problem only once they reach a "tipping point where cooperation may shade off into collusion, thereby subverting the ethical basis of the system." 288

In 1995, Professor John Coffee lamented in the class context, "[t]hese circumstances supply the preconditions for collusion between defendants and a favored plaintiffs' counsel: repeat players, a single forum in which the court is eager to achieve a global settlement, and 'passive' future claimants."289 He went on to distinguish between "old" collusion, where there is an actual or implicit agreement in which defendants settle cheaply in exchange for higher plaintiffs' attorneys fees, ${ }^{290}$ and "new" collusion through inventory settlements as side deals to a settlement class, double-dipping by serving as both class counsel and individual counsel for opt-outs, and striking deals that restrict claimants' eligibility through rigorous claims criteria. ${ }^{291}$ Some of these scenarios resonate with the settlements examined, such as Propulsid's claims process, reversion clauses, and direct fee negotiation; Biomet's direct fee agreement with the defendant and potentially doubled attorneys' fees; DePuy ASR's reversion clause; and both DePuy ASR and Zimmer Durom Hip Cup's reductions for nonclient, unrepresented plaintiffs, which are similar to paying one's inventory clients more than class members-a practice the Supreme Court struck down in Amchem Products, Inc. $v$. Windsor and Ortiz v. Fibreboard Corp. ${ }^{292}$

Of course, there are some important distinctions between class and nonclass aggregation: nonclass aggregation cannot bind those not before the court as a class action can. Because plaintiffs are present and have filed suit, conventional thinking suggests that plaintiffs' consent to settle is enough; there is no need to layer in judicial supervision as there is when absent

286 Abraham S. Blumberg, The Practice of Law as a Confidence Game: Organizational Cooptation of a Profession, 1 L. \& SOC'Y REV. 15, 20-21, 24 (1967).

287 Id. at 24.

288 Skolnick, supra note 284, at 69.

289 John C. Coffee, Jr., Class Wars: The Dilemma of the Mass Tort Class Action, 95 COLUM. L. REV. 1343, 1366-67 (1995).

290 Id. at 1367.

291 Id. at $1373-78$.

292 Amchem Prods., Inc. v. Windsor, 521 U.S. 591, 599 (1997); Ortiz v. Fibreboard Corp., 527 U.S. 815, 854 (1999). 
class members' rights are at stake. But our findings suggest that attorneys' financial interests may muddy plaintiffs' consent since clients typically follow their attorney's advice. ${ }^{293}$ Lawyers' finances may be intertwined with each other not only through settlement provisions that condition the deal (and attorneys' fees) on achieving a certain plaintiff participation rate, but also through formal joint venture agreements and informal promises to distribute common-benefit work and leadership positions to allies. Longstanding principal-agent research suggests that agents' financial self-interest may color their advice to clients. ${ }^{294}$ Just as they do in the class action and criminal context, repeat players face systemic temptations to be more loyal to each other or even to defendants, than to their own clients. ${ }^{295}$

Individual plaintiffs' attorneys' lack of litigation leverage and power may compound these temptations. Ordinarily, even an out-gunned and out-manned plaintiffs' lawyer squaring off against a well-heeled defendant can threaten to take a case to trial on a shoestring budget. But multidistrict litigation takes away that bargaining chip for all but a handful of bellwether cases; transferee judges rarely remand cases for trial. ${ }^{296}$ When combined with plaintiffs' attorneys' interlaced financial interests and a tightly connected social network, that lack of leverage against defendants turns into a lack of power for individual attorneys who might otherwise act as a check on questionable settlement practices.

Repeat players' relationships with one another may likewise play a critical role in creating social norms and perpetuating practices that push ethical boundaries. Regular interaction could lead plaintiffs' attorneys to have stronger social and relational ties to each other than to one-time clients, and could prompt them to identify as a group. ${ }^{297}$ Groups tend to catalyze

293 See Jeffrey H. Goldfien \& Jennifer K. Robbennolt, What if the Lawyers Have Their Way? An Empirical Assessment of Conflict Strategies and Attitudes Toward Mediation Styles, 22 OHIO ST. J. ON DISP. RESOL. 277, 285 (2007); Gordon, supra note 32, at 30; Korobkin \& Guthrie, supra note 32, at 82; Jean R. Sternlight, Lawyers' Representation of Clients in Mediation: Using Economics and Psychology to Structure Advocacy in a Nonadversarial Setting, 14 OHIO ST. J. ON DISP. RESOL. 269, 291-97, 318-19 (1999).

294 John C. Coffee, Jr., Professional Responsibility and the Corporate Lawyer, 13 Geo. J. Legal ETHICS 331, 340-41 (2000); Charles Silver, Merging Roles: Mass Tort Lawyers as Agents and Trustees, 31 PEPP. L. REV. 301, 302 (2003).

295 See supra note 34 and accompanying text.

296 Burch, supra note 58, at 410-20.

297 See ElLICKSON, supra note 66, at 177-78 ("A group is close-knit when informal power is broadly distributed among group members and the information pertinent to informal control circulates easily among them."); Blumberg, supra 
when people work toward a common goal like prevailing against a particular defendant, share physical and social immediacy as leaders must when working together, and have overlapping common norms such as those inherent in championing citizens' rights. ${ }^{298}$ Once a group forms, research shows that members exhibit other-regarding preferencestrust, reciprocity, and altruism-toward other members. ${ }^{299}$ Enduring groups comprised of long-term friends, colleagues, and business associates tend to cooperate to achieve the best collective outcome for the group. ${ }^{300}$ And studies demonstrate that their fairness considerations can change based on whether the situation involves another group member (inclusionary concerns for other repeat actors, perhaps) or individuals outside the group (exclusionary concerns for one-time clients). ${ }^{301}$

Should members observe other members at the top of the social hierarchy (perhaps those who rank highly in degree centrality) acting unethically, then that behavior may become the descriptive norm. ${ }^{302}$ When the lines between ethical and unethical behavior are blurred, as they are in an aggregate litigation system founded on an individual dispute resolution model, ${ }^{303}$ people tend to categorize their actions positively so as to avoid impacting their own self-image. ${ }^{304}$ If group members embrace higher levels of unethical behavior, then that behavior

note 286, at 24; Daniel J. Brass et al., Relationships and Unethical Behavior: A Social Network Perspective, 23 ACAD. OF MGMT. REV. 14, 17 (1998).

298 See Albert A. Cota et al., The Structure of Group Cohesion, 21 PERSONALITY \& Soc. PSYCHOL. BULL. 572, 574, 577 (1995); R. Scott Tindale et al., Shared Cognition in Small Groups, in BLACKWELl HANDBOOK ON SOCIAL PSYCHOLOGY: GROUP PROCESSES 1, 5 (Michael A. Hoagg \& R. Scott Tindale, eds., 2001).

299 See Nancy R. Buchan et al., Let's Get Personal: An International Examination of the Influence of Communication, Culture and Social Distance on Other Regarding Preferences, 60 J. ECON. BEHAV. \& ORG. 373, 374-75 (2006) (reviewing the literature on other-regarding preferences).

300 See ElLICKSON, supra note 66, at 167 ("[M]embers of a close-knit group develop and maintain norms whose content serves to maximize the aggregate welfare that members obtain in their workaday affairs with one another."); Leigh Thompson et al., Cohesion and Respect: An Examination of Group Decision Making in Social and Escalation Dilemmas, 34 J. EXPER. SOC. PSYCHOL. 289, 291-92 (1998).

301 Tom R. Tyler \& E. Allan Lind, Intrinsic Versus Community-Based Justice Models: When Does Group Membership Matter?, 46 J. SOC. IsSUES 83, 84-86 (1990).

302 Gina et al., supra note 24, at 394, 396, 398.

303 Baker, supra note 23, at 298-304.

304 See M.E. Schwitzer \& C.K. Hsee, Stretching the Truth: Elastic Justification and Motivated Communication of Uncertain Information, 25 J. RISK \& UNCERTAINTY 185, 185-86 (2002). 
can turn into an accepted practice. ${ }^{305}$ Put simply, unethical behavior, particularly among in-group members, can be contagious. ${ }^{306}$

In-groups comprised of highly connected actors likewise tend to police themselves internally through social and financial sanctions. ${ }^{307}$ As the social network illustrates, repeat players form dyadic relationships to others, which not only allows knowledge of common settlement practices to flow freely among them, but also information about cooperative and uncooperative behaviors, and attorneys' reputations as collaborators, contrarians, or defectors. The easy flow of information may enable leaders to credibly punish and reward others for following or disregarding norms, which decreases the likelihood that information about tacit or explicit collusion would surface or that members would raise ethical concerns about settlement practices on their client's behalf. ${ }^{308}$ Our anecdotal evidence bears this out. In-group attorneys spoke with us freely only on the condition of anonymity, for defecting in one proceeding could prompt financial repercussions in concurrent and future proceedings. After all, when judges defer to attorneys to pick their own leaders through the consensus method and appoint lead lawyers to serve on fee-allocation committees, they can give repeat players substantial enforcement tools.

This leaves us with a new variant on the timeless principalagent concern that, without monitoring, agents may disserve their principals to benefit themselves: lead lawyers as agents may disserve out-group principals with whom they seldom interact to immediately benefit lead lawyers' collective interests

305 See Gina et al., supra note 24, at 393-94; see also Fehr \& Fischbacher, supra note 24 , at 186-87 (discussing the relationship between social norms and punishment).

306 See Gina et al., supra note 24, at 398.

307 E.g., ElLICKSON, supra note 66, at 208-10, 225-29, 230-33.

308 See CHRISTAKIS \& FOWLER, supra note 18, at 160-61 (noting how networks among boards of directors allow for collusion and market manipulation); Fehr \& Fischbacher, supra note 24, at 187-88 (2004) (observing that where opportunities to punish exist, "cooperation flourishes" and that punishment might occur "because [the subjects] view unilateral defection as an unfair act that violates the conditional cooperation norm and thus deserves retaliation"); Ernst Fehr \& Simon Gachter, Fairness and Retaliation: The Economics of Reciprocity, 14 J. ECON. PERSPECTIVES 159, 168-70 (2000) (finding that in situations with incomplete contracts-like those for distributing common-benefit work and common-benefit funds among multidistrict litigation attorneys-the power to behave reciprocally by rewarding cooperators and punishing defectors substantially contributes to contract enforcement). 
and to better their own, individual interests over time. ${ }^{309}$ Attorneys on the social network's periphery might further their own interests by cooperating with questionable practices; this could earn them trust from the current group leaders and position them for future leadership roles as well as the lucrative common-benefit fees that accompany them. It likewise adds insight into the path dependencies that led to Professor Coffee's conclusion that "[o]nce bent, legal rules tend to stay bent."310 Questionable practices may be entrenched and replicated not only because they benefit repeat actors, but because they might be woven into the legal, social, and ethical culture.

\section{Implications for Law Reform}

Stepping back and looking more broadly at the social network suggests that the behaviors of controlling stakeholdersplaintiffs' attorneys, defense attorneys, defendants, and even judges-cannot be understood in isolation. As social norms so aptly illustrate, each agent adjusts to feedback from a variety of sources and circumstances such as Rule 23's absence, judicial selection criteria, agents' needs, parties' desires, ethical cultures, legislation, and of course the underlying facts and law. Agents adapt. ${ }^{311}$ As the evolution of Propulsid's settlement provisions demonstrate, new practices emerge from past successes and failures. Dissecting the discrete settlements that repeat actors design and viewing them in the aggregate allows us to identify emergent properties and trends. ${ }^{312}$

Understanding how these agents interact, change, and acclimate-what, in other words, makes multidistrict litigation complex - can help us formulate more realistic and useful propositions about how we might improve the system. Of course, some existing theories already explain basic interactions. For instance, the prisoner's dilemma-where players decide whether to cooperate with one another by staying silent or to defect by giving the other player up in return for a shorter sentence-helps us understand bilateral, strategic interactions

309 See Blumberg, supra note 286, at 24 ("Close and continuing relations between the lawyer 'regular' and his former colleagues in the prosecutor's office generally overshadow the relationship between the regular and his client.").

310 Coffee, supra note 289, at 1463.

311 MiLler \& PAGE, supra note 17, at 50, 53, 178-81.

312 See id. at 46 (discussing theories of emergence); Tom De Wolf \& Tom Holvoet, Emergence Versus Self-Organisation: Different Concepts but Promising When Combined, in ENGINEERING SELF-ORGANISING SySTEMS: METHOdOLOGIES AND APPLiCATIONS 1, 3 (Sven A. Brueckner et al. eds., 2005). 
without much complexity. ${ }^{313}$ Likewise, tit-for-tat strategies in repeated situations-where players cooperate upon first interacting with someone, but retaliate when cooperation is not reciprocated-can help us understand how interconnected repeat players may profit more financially over time by working together than objecting to questionable practices. ${ }^{314}$ It can also shed light on why a one-shotter attorney may be better off defecting (by objecting when excluded from leadership or not cooperating when the usual practices diverge from her client's best interest, for example) unless she hopes to become a repeat player. ${ }^{315}$

But these traditional analytic tools tend to break down when many people interact-multiple claimants, attorneys, defendants, judges, rules committees, and legislatures. ${ }^{316}$ It is the difference between tic-tac-toe and chess. ${ }^{317}$ Unlike conventional tools, complex adaptive systems theory, the theory that underpins social network analysis, allows us to consider agents' interconnectivity.

Characterizing multidistrict litigation as a complex adaptive system alongside things like cities, stock markets, and grasslands provides a way to explore the complexity and adaptivity inherent in those proceedings. ${ }^{318}$ Across the board, these systems share characteristics that are not perfectly patterned, completely random, or entirely chaotic. Instead, they include sophisticated agents who evolve to capitalize on changing circumstances, and act strategically in ways that are sometimes rational and sometimes not. 319 Like other complex adaptive systems, multidistrict proceedings include diverse, connected, interdependent, networked agents that interact repeatedly and

313 M.A. Nowak \& R.M. May, Evolutionary Games and Spatial Chaos, 359 NATURE 826, 826 (1992); M.A. Nowak, \& R.M. May, The Spatial Dilemmas of Evolution, 3 INT'L J. BIFURCATION \& CHAOS 1, 35-36 (1993).

314 See generally R. AXELROD, THE EVOLUTION CORPORATION (1984); Fehr \& Fischbacher, supra note 24, at 186.

315 E.g., Alison Frankel, Lance Cooper Lost Big in Attack on GM Lead Counselbut Did MDL Process Win?, REUTERS, Feb. 11, 2016 (discussing non-repeat player Lance Cooper's objections to lead lawyers' conduct in litigation against General Motors); Barry Meier, Lawyer for Plaintiffs Suing G.M. Steps Up Criticism of Another, N.Y. TIMES, Feb. 7, 2016, at B4 (same).

316 See Miller \& PAGE, supra note 17, at 221.

317 See id. at 220.

318 No single definition exists, but a good working definition is as follows: "the study of systems comprised of a macroscopic, heterogeneous set of autonomous agents interacting and adapting in response to one another and to external environment inputs.” J.B. Ruhl, Law's Complexity: A Primer, 24 GA. ST. L. REv. 885, 893 (2008).

319 See Scott E. PAGE, Diversity AND CompleXity 7-8 (2011). 
generate adaptive outcomes that cannot be isolated into their component parts. ${ }^{320}$ The patterns that emerge are neither completely ordered nor totally arbitrary. Plaintiffs' lawyers do not randomly pair with one another to form coalitions (as models for considering the spread of disease often assume), nor does everyone within the plaintiffs' bar interact simultaneously with everyone else (like political models often suppose).

Complexity arises when agents like repeat players depend on each other and that dependence spurs system-wide effects. ${ }^{321}$ Take grasslands, for example. The species in that environment interact in many different ways, which builds network connectivity. Substituting one agent, say a "sit-and-wait" spider (or an experienced but less centrally networked attorney) with an "active hunting" spider (a central repeat player) can set off a chain reaction: to avoid becoming the active spider's prey, grasshoppers change their feeding strategy, which likewise alters vegetation. ${ }^{322}$ Agents adapt through feedback and produce effects beyond their bilateral interactions. Once active hunting spiders infiltrate an area as repeat players have done in multidistrict leadership, they may create a pattern that makes inroads by sit-and-wait spiders increasingly difficult, thereby establishing "path dependence."323

Path dependence isn't limited to grasslands and spiders. When Congress passed the Private Securities Litigation Reform Act (PSLRA), for example, it aimed to reform and dislodge classaction lawyers-Milberg Weiss, in particular-by creating a presumption that the most adequate plaintiff is the one with the largest financial interest. ${ }^{324}$ Congress's hope was that this would instill a sophisticated, incentivized entity to monitor plaintiffs' lawyers. But rather than displacing large plaintiffs' firms, the PSLRA entrenched them; ${ }^{325}$ one study published eight years after PSLRA's enactment showed Milberg Weiss as lead or co-lead counsel in over $50 \%$ of the cases. ${ }^{326}$ Why? To gain institutional clients with the biggest stakes, the plaintiffs'

320 See Miller \& PAGE, supra note 17, at 221; PAGE, supra note 319, at 7-8, 38; Ruhl, supra note 318 , at 889 .

321 See Miller \& PAGE, supra note 17, at 9.

322 Ruhl, supra note 318 , at 887.

323 Id. at 894.

324 S. Rep. No. 104-98, at 6, n.8 (1995) (citing William P. Barrett, I Have No Clients, ForBEs 52 (Oct. 11, 1993) (quoting William Lerach)).

325 Tamara Loomis, Milberg Weiss Stronger than Ever Despite Reform Act, THE LEGAL INTELLIGENCER, Apr. 25, 2003, at 4.

326 LaUra E. Simmons \& Ellen M. Ryan, Cornerstone RESEARCh, Post-Reform Act Securities lawsuits: Settlements Reported Through December 2003, at 14 (2003). 
bar had to spend significant resources to advertise, effectively boxing smaller firms out of the market. ${ }^{327}$ In short, the PSLRA actually benefitted larger, moneyed plaintiffs' firms like Milberg Weiss, created a concentrated bar, and established path dependence.

Likewise, when transferee judges use experience, cooperative tendencies, and an ability to finance the litigation as primary factors in selecting lead lawyers in multidistrict litigation, they entrench repeat players in leadership roles. But path dependence is not path permanence. Just as the active hunting spider might be "locked in" for now, another key feature of the complex adaptive system is "stable disequilibrium." 328 Change can constantly occur. If sit-and-wait spiders are less susceptible to harsh winters than the active hunting spider, then a particularly cold winter might prompt conditions ripe for change. ${ }^{329}$ Similarly, if non-repeat players faithfully defend their clients' best interests against their own self-interest and the self-interest of lead lawyers, then ethical clarifications and external measures that promote competition might provoke change, too. External adjustments such as the passage of the Class Action Fairness Act can upset the balance in complex litigation as well. ${ }^{330}$ Nevertheless, because of agents' adaptivity, most change is incremental-not dramatic; entrenched agents are resilient, as the PSLRA example illustrates.

What then can we learn from situating multidistrict litigation as a complex adaptive system? First, drawing from its rich interdisciplinary literature, its core ideas, and its metaphors allows us make more realistic assumptions about the social activity, information, and behaviors that are likely to occur within multidistrict litigation's social network. ${ }^{331}$ There are certain patterns that emerge and hold true across all complex adaptive systems-ecosystems, political elections, and economies, for instance. Here are two: (1) diversity typically enhances complex systems' functionality and contributes to innovation and productivity; and (2) complex systems need

327 See Howard M. Erichson, CAFA's Impact on Class Action Lawyers, 156 U. PA. L. REV. 1593, 1604-05 (2008).

328 Ruhl, supra note 318 , at 895.

329 Id.

330 Class Action Fairness Act of $2005 \S \S 2$ (a), (b), Pub. L. No. 109-2, 119 Stat. 4,5 (codified in scattered sections of 28 U.S.C.); Erichson, supra note 327, at 1604-05.

331 See Miller \& PAGE, supra note 17, at 230 (observing that "there are deep commonalities-ones that do not respect the usual academic boundaries-across the various systems we observe in the world"). 
competition to flourish and diversity drives competition. ${ }^{332}$ When the same actors work together repeatedly, their thinking tends to converge, and emphasizing cooperation can dampen competition that might otherwise serve to safeguard plaintiffs' best interests. ${ }^{333}$

Second, using social network analysis to map connections between agents in multidistrict litigation reveals links that cannot be seen by the naked eye. Those connections allow us to develop some working hypotheses about the level of repeat play and the kind of social interactions that might occur when agents encounter one another in well-defined networks. Consider three such possibilities. First, when attorneys become lead lawyers, they and their allies have the power to distribute common-benefit work, suggest fee allocations, and report uncooperative behavior to the judge-carrots and sticks, in other words. ${ }^{334}$ Second, judicial focus on experience, financial resources, and cooperation means that lead attorneys not only possess power in the current litigation, but will almost always have concurrent and future leadership opportunities to credibly punish or reward other attorneys. Finally, unlike gametheoretic computer exercises, repeat players likely have inside information about past behaviors and transactions through direct knowledge, gossip, and news reports. In short, reciprocity and reputation may prove integral to this close-knit group of lawyers: they may share information easily through their network, exercise power in future litigations, and credibly sanction and reward one another for following or disregarding norms that promote their collective interests.

Third, from there we can diagnose probable systemic dysfunctions. Multidistrict litigation is designed to promote pre-

332 See PAGE, supra note 319, at 8-9, 215-17.

333 See generally CASS R. SunSTEIN, WHY GROUPS Go TO EXTREMES (2008) (contending that deliberation among groups with diverse opinions prevents extremism); SUNSTEIN, supra note 120, at 145-47 (arguing that checks and balances in partisan politics constrains group polarization and extreme movements). Unlike group polarization and groupthink, confirmation bias is an individual bias that can be exacerbated or mollified by group decision-making. See Dieter Frey, $R e-$ cent Research on Selective Exposure to Information, in ADVANCES IN EXPERIMENTAL SOCIAL PSYCHOLOGY 41, 52-53 (Leonard Berkowitz ed., 1986); Stefan Schulz-Hardt et al., Biased Information Search in Group Decision Making, 78 J. PERSONALITY \& SOC. PSYCHOL. 655, 656-58 (2000).

334 Judges often appoint lead lawyers to fee allocation committees and solicit input on how to distribute attorneys' fees. Dubay, supra note 59, at 55-56, Tbl. 13.; see, e.g., In re Vioxx Prods. Liab. Litig., No. 05-md-1657 (E.D. La. June 13, 2012) (order appointing lead lawyers to fee allocation committee). Power need not be equal among members; they must simply have enough authority to credibly threaten to punish defectors. ELLICKSON, supra note 66, at 178-79. 
trial efficiency and consistency without altering core due process rights such as adequate representation and the right to have one's day in court. But settlements with provisions that principally benefit the attorneys or the defendant at the plaintiffs' expense might indicate that efficiency has trumped adequate representation. ${ }^{335}$ Recalibration may be in order.

Fourth, we can recognize the limited capacity to dramatically change the status quo and instead propose malleable methods that work with-not against - the inertia of a complex adaptive system. While federal rules committees and legislatures may seek changes that provoke paradigm shifts, ${ }^{336}$ the reality is that attorneys in this elite bar are adaptive, resilient, and likely to withstand these adjustments. Thus, the broader lesson is that enhancing functionality within multidistrict litigation may not hinge on top-down or external legislative reforms, but in harnessing an equally adaptive power that already lies within the system itself: competition. ${ }^{337}$ As the vast literature on collateral attacks in the class-action context illustrates, the plaintiffs' bar is highly competitive. ${ }^{338}$ But judicial selection methods and deference to repeat players may have muted open rivalry by encouraging and rewarding cooperation. Interconnected agents who benefit from the status quo are more likely to shun and ostracize objectors who threaten to disrupt their practices-particularly if that objection could derail a lucrative settlement. Consequently, the question going forward becomes how to tweak norms and design adjustments that capitalize on pre-existing competitive forces such that faithfully representing plaintiffs' interests becomes more lucrative than playing the long game. ${ }^{339}$

335 For an argument as to why Due Process protections of adequate representation should extend to nonclass multidistrict litigation in ways that are similar to class actions, see Burch, supra note 71, at 158-61, 179.

336 E.g., Class Action Fairness Act of 2005 §§ 2(a), (b), Pub. L. No. 109-2, 119 Stat. 4, 5 (codified in scattered sections of 28 U.S.C.); Advisory Committee on Civil Rules, Washington D.C., Apr. 9-10, 2015, at 39-41, available at http://www .uscourts.gov/uscourts/RulesAndPolicies/rules/Agenda\%20Books/Civil/ CV2015-04.pdf [https://perma.cc/T77P-4JU2]; Jeffrey D. Koelemay, Bill to Curb Class Suits Clears Committee; Civil Rights Plaintiffs Thrown a Bone, 16 BNA CLASS ACTION RPT. 718 (June 24, 2015).

337 For proposed reforms based on competition, see Burch, supra note 71, at 168-85.

338 E.g., Epstein v. MCA, Inc., 179 F.3d 641 (9th Cir. 1999) (prohibiting a collateral attack); Patrick Woolley, The Availability of Collateral Attack for Inadequate Representation in Class Suits, 79 TEX. L. REV. 383, 384-87 (2000).

339 Building from the insights in this Article, Monopolies in Multidistrict Litigation proposes just such a theory. Burch, supra note 71, at 135-54. 
APPENDIX

TABle A1: Multidistrict Litigation DataseT

CASE LISTS

\begin{tabular}{|c|c|c|c|c|c|}
\hline Litigation Name & $\begin{array}{l}\text { MDL } \\
\text { Number }\end{array}$ & Filed & Coordinated & Closed & District \\
\hline $\begin{array}{l}\text { In re: Asbestos Prod. Liab. } \\
\text { Litig. (No. VI) }\end{array}$ & 875 & $1 / 17 / 91$ & $7 / 29 / 91$ & pending & $\begin{array}{l}\text { E. D. } \\
\text { Penn. }\end{array}$ \\
\hline $\begin{array}{l}\text { In re: Factor VIII or IX } \\
\text { Concentrate Blood Products } \\
\text { Prod. Liab. Litig. }\end{array}$ & 986 & $7 / 13 / 93$ & $12 / 7 / 93$ & $12 / 31 / 13$ & N. D. Ill. \\
\hline $\begin{array}{l}\text { In re: Diet Drugs } \\
\text { (Phentermine/Fenfluramine/ } \\
\text { Dexfenfluramine) Prod. Liab. } \\
\text { Litig. }\end{array}$ & 1203 & $9 / 23 / 97$ & $12 / 10 / 97$ & pending & $\begin{array}{l}\text { E. D. } \\
\text { Penn. }\end{array}$ \\
\hline $\begin{array}{l}\text { In re: Propulsid Prod. Liab. } \\
\text { Litig. }\end{array}$ & 1355 & $5 / 24 / 00$ & $8 / 7 / 00$ & $10 / 21 / 13$ & E. D. La. \\
\hline $\begin{array}{l}\text { In re: Methyl Tertiary Butyl } \\
\text { Ether ("MTBE") Prod. Liab. } \\
\text { Litig. }\end{array}$ & 1358 & $6 / 6 / 00$ & $10 / 10 / 00$ & pending & S.D.N.Y \\
\hline In re: Baycol Prod. Liab. Litig. & 1431 & $8 / 21 / 01$ & $12 / 18 / 01$ & pending & D. Minn. \\
\hline $\begin{array}{l}\text { In re: Neurontin Marketing, } \\
\text { Sales Practices and Prod. } \\
\text { Liab. Litig. }\end{array}$ & 1479 & $4 / 30 / 02$ & $8 / 15 / 02$ & $12 / 18 / 14$ & D. Mass. \\
\hline $\begin{array}{l}\text { In re: Prempro Prod. Liab. } \\
\text { Litig. }\end{array}$ & 1507 & $10 / 18 / 02$ & $3 / 4 / 03$ & $3 / 11 / 16$ & $\begin{array}{l}\text { E.D. } \\
\text { Ark. }\end{array}$ \\
\hline $\begin{array}{l}\text { In re: Accutane (Isotrentinoin) } \\
\text { Prod. Liab. Litig. }\end{array}$ & 1626 & $6 / 7 / 04$ & $11 / 1 / 04$ & $8 / 4 / 15$ & M. D. Fl. \\
\hline In re: Vioxx Prod. Liab. Litig. & 1657 & $10 / 8 / 04$ & $2 / 16 / 05$ & pending & E. D. La. \\
\hline $\begin{array}{l}\text { In re: Ford Motor Co. E-350 } \\
\text { Van Prod. Liab. Litig. (No. II) }\end{array}$ & 1687 & $3 / 16 / 05$ & $6 / 16 / 05$ & $7 / 15 / 13$ & D.N.J. \\
\hline $\begin{array}{l}\text { In re: Ford Motor Co. Speed } \\
\text { Control Deactivation Switch } \\
\text { Prod. Liab. Litig. }\end{array}$ & 1718 & $7 / 15 / 05$ & $8 / 9 / 06$ & $8 / 6 / 13$ & $\begin{array}{l}\text { E. D. } \\
\text { Mich. }\end{array}$ \\
\hline $\begin{array}{l}\text { In re: Celexa and Lexapro } \\
\text { Prod. Liab. Litig. }\end{array}$ & 1736 & $11 / 9 / 05$ & $2 / 17 / 06$ & $9 / 4 / 13$ & $\begin{array}{l}\text { E. D. } \\
\text { Mo. }\end{array}$ \\
\hline $\begin{array}{l}\text { In re: OrthoEvra Prod. Liab. } \\
\text { Litig. }\end{array}$ & 1742 & $11 / 28 / 05$ & $3 / 1 / 06$ & $1 / 7 / 15$ & $\begin{array}{l}\text { N.D. } \\
\text { Ohio }\end{array}$ \\
\hline $\begin{array}{l}\text { In re: Aredia and Zometa Prod. } \\
\text { Liab. Litig. }\end{array}$ & 1760 & $1 / 27 / 06$ & $4 / 18 / 06$ & $9 / 26 / 14$ & $\begin{array}{l}\text { M.D. } \\
\text { Tenn. }\end{array}$ \\
\hline $\begin{array}{l}\text { In re: Human Tissue Prod. } \\
\text { Liab. Litig. }\end{array}$ & 1763 & $2 / 7 / 06$ & $6 / 13 / 07$ & $11 / 5 / 13$ & D.N.J. \\
\hline $\begin{array}{l}\text { In re: Fosamax Prod. Liab. } \\
\text { Litig. (MDL 1789) }\end{array}$ & 1789 & $5 / 24 / 06$ & $2 / 15 / 07$ & pending & S.D.N.Y \\
\hline $\begin{array}{l}\text { In re: Mirapex Prod. Liab. } \\
\text { Litig. }\end{array}$ & 1836 & $2 / 6 / 07$ & $6 / 22 / 07$ & pending & D. Minn. \\
\hline $\begin{array}{l}\text { In re: Kugel Mesh Hernia } \\
\text { Patch Prod. Liab. Litig. }\end{array}$ & 1842 & $2 / 28 / 07$ & $6 / 22 / 07$ & pending & $\begin{array}{l}\text { D. } \\
\text { Rhode } \\
\text { Island }\end{array}$ \\
\hline $\begin{array}{l}\text { In re: ConAgra Peanut Butter } \\
\text { Prod. Liab. Litig. }\end{array}$ & 1845 & $3 / 6 / 07$ & $6 / 17 / 07$ & $4 / 2 / 15$ & $\begin{array}{l}\text { N. D. } \\
\text { Ga. }\end{array}$ \\
\hline $\begin{array}{l}\text { In re: Avandia Marketing Sales } \\
\text { Practices and Prod. Liab. Litig. }\end{array}$ & 1871 & $6 / 11 / 07$ & $10 / 16 / 07$ & pending & $\begin{array}{l}\text { E. D. } \\
\text { Penn. }\end{array}$ \\
\hline
\end{tabular}




\begin{tabular}{|c|c|c|c|c|c|}
\hline Litigation Name & $\begin{array}{l}\text { MDL } \\
\text { Number }\end{array}$ & Filed & Coordinated & Closed & District \\
\hline $\begin{array}{l}\text { In re: FEMA Trailer } \\
\text { Formaldehyde Prod. Liab. } \\
\text { Litig. }\end{array}$ & 1873 & $6 / 12 / 07$ & $10 / 24 / 07$ & $5 / 11 / 15$ & E. D. La. \\
\hline $\begin{array}{l}\text { In re: Gadolinium Contrast } \\
\text { Dyes Prod. Liab. Litig. }\end{array}$ & 1909 & $10 / 26 / 07$ & $2 / 27 / 08$ & $4 / 30 / 15$ & $\begin{array}{l}\text { N.D. } \\
\text { Ohio }\end{array}$ \\
\hline $\begin{array}{l}\text { In re: Trasylol Prod. Liab. } \\
\text { Litig. }\end{array}$ & 1928 & $1 / 3 / 08$ & $4 / 7 / 08$ & $8 / 10 / 15$ & S. D. Fl. \\
\hline $\begin{array}{l}\text { In re: Levaquin Prod. Liab. } \\
\text { Litig. }\end{array}$ & 1943 & $2 / 19 / 08$ & $6 / 13 / 08$ & pending & D. Minn. \\
\hline $\begin{array}{l}\text { In re: Heparin Prod. Liab. } \\
\text { Litig. }\end{array}$ & 1953 & 4/4/08 & $6 / 6 / 08$ & $9 / 23 / 16$ & $\begin{array}{l}\text { N.D. } \\
\text { Ohio }\end{array}$ \\
\hline $\begin{array}{l}\text { In re: Zurn Pex Plumbing } \\
\text { Prod. Liab. Litig. }\end{array}$ & 1958 & $4 / 21 / 08$ & $8 / 21 / 08$ & $8 / 1 / 13$ & D. Minn. \\
\hline $\begin{array}{l}\text { In re: NuvaRing Prod. Liab. } \\
\text { Litig. }\end{array}$ & 1964 & $5 / 9 / 08$ & $8 / 22 / 08$ & pending & $\begin{array}{l}\text { E. D. } \\
\text { Mo. }\end{array}$ \\
\hline $\begin{array}{l}\text { In re: Bisphenol-A (BPA) } \\
\text { Polycarbonate Plastics Prod. } \\
\text { Liab. Litig. }\end{array}$ & 1967 & $5 / 23 / 08$ & $8 / 13 / 08$ & $7 / 19 / 13$ & $\begin{array}{l}\text { W. D. } \\
\text { Mo. }\end{array}$ \\
\hline $\begin{array}{l}\text { In re: Whirlpool Corp. Front- } \\
\text { Loading Washer Prod. Liab. } \\
\text { Litig. }\end{array}$ & 2001 & $9 / 26 / 08$ & $12 / 20 / 08$ & $9 / 29 / 16$ & $\begin{array}{l}\text { N.D. } \\
\text { Ohio }\end{array}$ \\
\hline $\begin{array}{l}\text { In re: Mentor Corp. ObTape } \\
\text { Transobuturator Sling Prod. } \\
\text { Liab. Litig. }\end{array}$ & 2004 & $10 / 14 / 08$ & $12 / 3 / 08$ & pending & $\begin{array}{l}\text { M. D. } \\
\text { Ga. }\end{array}$ \\
\hline $\begin{array}{l}\text { In re: Land Rover LR3 Tire } \\
\text { Wear Products Liability } \\
\text { Litigation }\end{array}$ & 2008 & $10 / 29 / 08$ & 2/23/09 & $8 / 7 / 13$ & $\begin{array}{l}\text { C. D. } \\
\text { Cal. }\end{array}$ \\
\hline $\begin{array}{l}\text { In re: Bayer Corp. } \\
\text { Combination Asprin Prod. } \\
\text { Marketing and Sales Practices } \\
\text { Litig. }\end{array}$ & 2023 & $1 / 6 / 09$ & 4/14/09 & $5 / 14 / 14$ & E.D.N.Y. \\
\hline $\begin{array}{l}\text { In re: Apple iPhone } 3 G \\
\text { Products Liability Litigation }\end{array}$ & 2045 & 3/11/09 & $7 / 1 / 09$ & $7 / 10 / 14$ & $\begin{array}{l}\text { N. D. } \\
\text { Cal. }\end{array}$ \\
\hline $\begin{array}{l}\text { In re: Chinese-Manufactured } \\
\text { Drywall Prod. Liab. Litig. }\end{array}$ & 2047 & $3 / 13 / 09$ & $6 / 15 / 09$ & pending & E. D. La. \\
\hline $\begin{array}{l}\text { In re: Denture Cream } \\
\text { Products Liab. Litig. }\end{array}$ & 2051 & $3 / 24 / 09$ & 6/9/09 & $11 / 16 / 15$ & S. D. Fl. \\
\hline In re: Chantix Prod. Liab. Litig & 2092 & $7 / 8 / 09$ & $10 / 1 / 09$ & $10 / 6 / 14$ & N.D. Al. \\
\hline $\begin{array}{l}\text { In re: Yasmin and Yaz } \\
\text { (Drospirenone) Marketing , } \\
\text { Sales Practices Prod. Liab. } \\
\text { Litig. }\end{array}$ & 2100 & $7 / 30 / 09$ & $10 / 1 / 09$ & pending & S. D. Ill. \\
\hline $\begin{array}{l}\text { In re: IKO Roofing Shingle } \\
\text { Prod. Liab. Litig. }\end{array}$ & 2104 & $8 / 12 / 09$ & $12 / 3 / 09$ & pending & C. D. Ill. \\
\hline $\begin{array}{l}\text { In re: Toyota Motor Corp. } \\
\text { Unintended Acceleration } \\
\text { Marketing, Sales Practices, } \\
\text { and Products Liab. Litig. }\end{array}$ & 2151 & $2 / 4 / 10$ & $4 / 9 / 10$ & pending & $\begin{array}{l}\text { C. D. } \\
\text { Cal. }\end{array}$ \\
\hline $\begin{array}{l}\text { In re: Zimmer Durom Hip Cup } \\
\text { Prod. Liab. Litig. }\end{array}$ & 2158 & $3 / 15 / 10$ & $6 / 9 / 10$ & pending & D.N.J. \\
\hline
\end{tabular}




\begin{tabular}{|c|c|c|c|c|c|}
\hline Litigation Name & $\begin{array}{l}\text { MDL } \\
\text { Number }\end{array}$ & Filed & Coordinated & Closed & District \\
\hline $\begin{array}{l}\text { In re: Toyota Motor Corp. } \\
\text { Hybrid Brake Marketing, Sales } \\
\text { Practices, and Products Liab. } \\
\text { Litig. }\end{array}$ & 2172 & $4 / 21 / 10$ & $8 / 17 / 10$ & $8 / 6 / 13$ & C.D Cal. \\
\hline $\begin{array}{l}\text { In re: Oil Spill by the Oil Rig } \\
\text { "Deepwater Horizon" in the } \\
\text { Gulf of Mexico, on April 20, } \\
2010\end{array}$ & 2179 & $5 / 6 / 10$ & $8 / 10 / 10$ & pending & E. D. La. \\
\hline $\begin{array}{l}\text { In re: C.R. Bard, Inc., Pelvic } \\
\text { Repair System Prod. Liab. } \\
\text { Litig. }\end{array}$ & 2187 & $7 / 15 / 10$ & $10 / 12 / 10$ & pending & $\begin{array}{l}\text { S. D. W. } \\
\text { Va. }\end{array}$ \\
\hline $\begin{array}{l}\text { In re: Apple Inc. iPhone } 4 \\
\text { Marketing, Sales Practices \& } \\
\text { Prod. Liab. Lit. }\end{array}$ & 2188 & $7 / 15 / 10$ & $10 / 8 / 10$ & $7 / 29 / 13$ & $\begin{array}{l}\text { N. D. } \\
\text { Cal. }\end{array}$ \\
\hline $\begin{array}{l}\text { In re: DePuy Orthopaedics } \\
\text { Inc., ASR Hip Implant Prod. } \\
\text { Liab. Litig. }\end{array}$ & 2197 & $9 / 3 / 10$ & $12 / 3 / 10$ & pending & $\begin{array}{l}\text { N.D. } \\
\text { Ohio }\end{array}$ \\
\hline $\begin{array}{l}\text { In re: Navistar } 6.0 \text { Diesel } \\
\text { Engine Prod. Liab. Litig. }\end{array}$ & 2223 & $12 / 10 / 10$ & $4 / 13 / 11$ & $7 / 18 / 13$ & N. D. Ill. \\
\hline $\begin{array}{l}\text { In re: Darvocet, Darvon and } \\
\text { Propoxyphene Prod. Liab. } \\
\text { Litig. }\end{array}$ & 2226 & $12 / 15 / 10$ & $8 / 16 / 11$ & $3 / 16 / 17$ & E.D. Ky. \\
\hline $\begin{array}{l}\text { In re: Porsche Cars North } \\
\text { America Inc. Plastic Coolant } \\
\text { Tubes Prod. Liab. Litig. }\end{array}$ & 2233 & $2 / 16 / 11$ & $5 / 23 / 11$ & $3 / 19 / 14$ & $\begin{array}{l}\text { S.D. } \\
\text { Ohio }\end{array}$ \\
\hline $\begin{array}{l}\text { In re: Fosamax (Alendronate } \\
\text { Sodium) Prod. Liab. Litig. (No. } \\
\text { II) }\end{array}$ & 2243 & $3 / 24 / 11$ & $2 / 3 / 12$ & pending & D.N.J. \\
\hline $\begin{array}{l}\text { In re: DePuy Orthopaedics, } \\
\text { Inc., Pinnacle Hip Implant } \\
\text { Prod. Liab. Litig. }\end{array}$ & 2244 & $3 / 28 / 11$ & $2 / 8 / 12$ & pending & $\begin{array}{l}\text { N.D. } \\
\text { Texas }\end{array}$ \\
\hline $\begin{array}{l}\text { In re: Zimmer Nexgen Knee } \\
\text { Implant Prod. Liab. Litig. }\end{array}$ & 2272 & $6 / 6 / 11$ & $8 / 8 / 11$ & pending & E. D. Ill. \\
\hline $\begin{array}{l}\text { In re: Building Materials } \\
\text { Corporation of America } \\
\text { Asphalt Roofing Shingle Prod. } \\
\text { Liab. Litig. }\end{array}$ & 2283 & $7 / 14 / 11$ & $10 / 11 / 11$ & $7 / 15 / 14$ & $\begin{array}{l}\text { D. S. } \\
\text { Carolina }\end{array}$ \\
\hline $\begin{array}{l}\text { In re: Imprelis Herbicide } \\
\text { Marketing, Sales Practice, and } \\
\text { Prod. Liab. Litig. }\end{array}$ & 2284 & $7 / 22 / 11$ & $10 / 20 / 11$ & pending & $\begin{array}{l}\text { E. D. } \\
\text { Penn. }\end{array}$ \\
\hline $\begin{array}{l}\text { In re: Actos (Pioglitazone) } \\
\text { Prod. Liab. Litig. }\end{array}$ & 2299 & $8 / 31 / 11$ & $12 / 29 / 11$ & pending & $\begin{array}{l}\text { W. D. } \\
\text { La. }\end{array}$ \\
\hline $\begin{array}{l}\text { In re: Skechers Toning Shoe } \\
\text { Prod. Liab.Litig. }\end{array}$ & 2308 & $9 / 30 / 11$ & $12 / 19 / 11$ & pending & $\begin{array}{l}\text { W. D. } \\
\text { Ky. }\end{array}$ \\
\hline $\begin{array}{l}\text { In re: Ford Motor Co. Spark } \\
\text { Plug and 3-Valve Engine Prod. } \\
\text { Liab. Litig. }\end{array}$ & 2316 & $10 / 21 / 11$ & $2 / 8 / 12$ & $2 / 5 / 16$ & $\begin{array}{l}\text { N.D. } \\
\text { Ohio }\end{array}$ \\
\hline $\begin{array}{l}\text { In re: American Medical } \\
\text { Systems Inc., Pelvic Repair } \\
\text { System, Prod. Liab. Litig. }\end{array}$ & 2325 & $11 / 23 / 11$ & $2 / 7 / 12$ & pending & $\begin{array}{l}\text { S. D. W. } \\
\text { Va. }\end{array}$ \\
\hline $\begin{array}{l}\text { In re: Boston Scientific Corp } \\
\text { Pelvic Repair Sys. Prods. Liab. }\end{array}$ & 2326 & $11 / 28 / 11$ & $2 / 7 / 12$ & pending & S.D.W.V. \\
\hline
\end{tabular}

Pelvic Repair Sys. Prods. Liab. Litig. 


\begin{tabular}{|c|c|c|c|c|c|}
\hline Litigation Name & $\begin{array}{l}\text { MDL } \\
\text { Number }\end{array}$ & Filed & Coordinated & Closed & District \\
\hline $\begin{array}{l}\text { In re: Ethicon, Inc. Pelvic } \\
\text { Repair Sys. Prods. Liab. Litig. }\end{array}$ & 2327 & $11 / 28 / 11$ & $2 / 7 / 12$ & pending & $\begin{array}{l}\text { S. D. W. } \\
\text { Va. }\end{array}$ \\
\hline $\begin{array}{l}\text { In re: Wright Medical } \\
\text { Technology, Inc., Conserve } \\
\text { Hip Implant Prod. Liab. Litig. }\end{array}$ & 2329 & $11 / 29 / 11$ & $2 / 8 / 12$ & pending & $\begin{array}{l}\text { N. D. } \\
\text { Ga. }\end{array}$ \\
\hline $\begin{array}{l}\text { In re: Propecia (Finasteride) } \\
\text { Prod. Liab. Litig. }\end{array}$ & 2331 & $12 / 6 / 11$ & $4 / 16 / 12$ & pending & E.D.N.Y \\
\hline $\begin{array}{l}\text { In re: MI Windows \& Doors, } \\
\text { Inc., Prod. Liab. Litig. }\end{array}$ & 2333 & $12 / 8 / 11$ & $4 / 23 / 12$ & $8 / 4 / 15$ & $\begin{array}{l}\text { D. S. } \\
\text { Carolina }\end{array}$ \\
\hline $\begin{array}{l}\text { In re: Zoloft (Sertraline } \\
\text { Hydrochloride) Prod. Liab. } \\
\text { Litig. }\end{array}$ & 2342 & $1 / 18 / 12$ & $4 / 17 / 12$ & pending & $\begin{array}{l}\text { E. D. } \\
\text { Penn. }\end{array}$ \\
\hline $\begin{array}{l}\text { In re: Watson Fentanyl Patch } \\
\text { Prod. Liab. Litig. }\end{array}$ & 2372 & $4 / 13 / 12$ & $8 / 7 / 12$ & $8 / 15 / 14$ & N. D. Ill. \\
\hline $\begin{array}{l}\text { In re: Pradaxa (Dabigatran } \\
\text { Etexilate) Prod. Liab. Litig. }\end{array}$ & 2385 & $5 / 30 / 12$ & $8 / 8 / 12$ & pending & S. D. Ill. \\
\hline $\begin{array}{l}\text { In re: Coloplast Corp. Pelvic } \\
\text { Support Sys. Prods. Liab. } \\
\text { Litig. }\end{array}$ & 2387 & $6 / 5 / 12$ & $8 / 6 / 12$ & pending & $\begin{array}{l}\text { S.D. W. } \\
\text { Va. }\end{array}$ \\
\hline $\begin{array}{l}\text { In re: Biomet M2a Magnum } \\
\text { Hip Implant Prod. Liab. Litig. }\end{array}$ & 2391 & $6 / 27 / 12$ & $10 / 2 / 12$ & pending & $\begin{array}{l}\text { N. D. } \\
\text { Ind. }\end{array}$ \\
\hline $\begin{array}{l}\text { In re: Nexium (Esomeprazole) } \\
\text { Products Liability Litigation }\end{array}$ & 2404 & $8 / 27 / 12$ & $12 / 6 / 12$ & $1 / 4 / 17$ & $\begin{array}{l}\text { C. D. } \\
\text { Cal. }\end{array}$ \\
\hline $\begin{array}{l}\text { In re: Plavix Marketing, Sales } \\
\text { Practices \& Prod. Liab. Litig. } \\
\text { (No. II) }\end{array}$ & 2418 & $10 / 15 / 12$ & $2 / 12 / 13$ & pending & D.N.J. \\
\hline $\begin{array}{l}\text { In re: New England } \\
\text { Compounding Pharmacy, Inc. } \\
\text { Prod. Liab. Litig. }\end{array}$ & 2419 & $10 / 16 / 12$ & $2 / 12 / 13$ & pending & D. Mass \\
\hline $\begin{array}{l}\text { In re: Fresenius } \\
\text { GranuFlo/NaturaLyte } \\
\text { Dialysate Prod. Liab. Litig. }\end{array}$ & 2428 & $12 / 12 / 12$ & $3 / 29 / 13$ & pending & D. Mass \\
\hline $\begin{array}{l}\text { In re: Mirena IUD Prod. Liab. } \\
\text { Litig. }\end{array}$ & 2434 & $1 / 16 / 13$ & $4 / 8 / 13$ & $8 / 9 / 16$ & S.D.N.Y \\
\hline $\begin{array}{l}\text { In re: Tylenol (Acetaminophen) } \\
\text { Marketing, Sales Practices and } \\
\text { Prod. Liab. Litig. }\end{array}$ & 2436 & $1 / 17 / 13$ & $4 / 1 / 13$ & pending & $\begin{array}{l}\text { E. D. } \\
\text { Penn. }\end{array}$ \\
\hline
\end{tabular}




\section{TABLE A2: TOP 50 REPEAT PlayeRS IN LEADERSHIP POSITIONS BY APPEARANCE TYPE}

\begin{tabular}{|c|c|c|c|c|c|c|c|}
\hline Attorney & 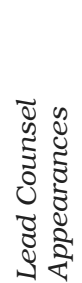 & 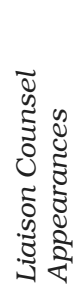 & 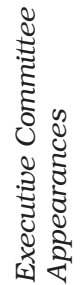 & 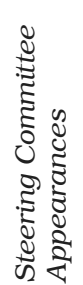 & 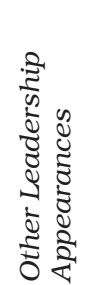 & 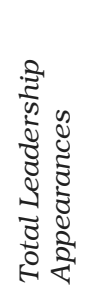 & 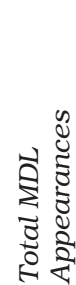 \\
\hline Arsenault, Richard & 3 & 1 & 2 & 13 & 2 & 21 & 18 \\
\hline Seeger, Christopher & 1 & 2 & 3 & 12 & 2 & 21 & 16 \\
\hline Nast, Dianne & 2 & 1 & 2 & 12 & 2 & 19 & 14 \\
\hline Becnel, Jr., Daniel & 0 & 1 & 2 & 11 & 0 & 14 & 14 \\
\hline Parker, Jerrold & 0 & 0 & 1 & 10 & 0 & 11 & 11 \\
\hline Conroy, Jayne & 1 & 1 & 1 & 8 & 1 & 12 & 10 \\
\hline Parfitt, Michelle & 0 & 1 & 2 & 8 & 0 & 11 & 10 \\
\hline Levin, Arnold & 2 & 1 & 1 & 8 & 3 & 15 & 9 \\
\hline Robinson, Jr., Mark & 2 & 1 & 2 & 7 & 2 & 14 & 10 \\
\hline London, Michael & 2 & 2 & 2 & 7 & 1 & 14 & 9 \\
\hline Crump, Martin & 0 & 0 & 1 & 7 & 0 & 8 & 8 \\
\hline DeBartolomeo, A.J. & 0 & 0 & 0 & 7 & 0 & 7 & 7 \\
\hline Flaherty, Yvonne & 0 & 0 & 0 & 7 & 0 & 7 & 7 \\
\hline Osborne, Joseph & 0 & 0 & 0 & 7 & 0 & 7 & 7 \\
\hline Thompson III, Fred & 3 & 1 & 1 & 6 & 1 & 12 & 8 \\
\hline Shkolnik, Hunter & 1 & 0 & 1 & 6 & 1 & 9 & 8 \\
\hline Restaino, John & 1 & 0 & 1 & 6 & 2 & 10 & 7 \\
\hline Cartmell, Thomas & 0 & 0 & 2 & 6 & 0 & 8 & 7 \\
\hline Dugan, II, James & 0 & 0 & 0 & 6 & 1 & 7 & 7 \\
\hline Zonies, Joseph & 0 & 0 & 1 & 6 & 0 & 7 & 6 \\
\hline Abrams, Rachel & 0 & 0 & 0 & 6 & 0 & 6 & 6 \\
\hline Blizzard, Edward & 0 & 0 & 0 & 6 & 0 & 6 & 6 \\
\hline Oliver, Alyson & 0 & 0 & 0 & 6 & 0 & 6 & 6 \\
\hline Lanier, W. Mark & 1 & 0 & 3 & 5 & 2 & 11 & 8 \\
\hline Flowers, Peter & 1 & 0 & 2 & 5 & 0 & 8 & 7 \\
\hline Matthews, David & 0 & 0 & 1 & 5 & 1 & 7 & 7 \\
\hline Meadow, Richard & 0 & 0 & 0 & 5 & 2 & 7 & 7 \\
\hline Anapol, Thomas & 1 & 0 & 0 & 5 & 1 & 7 & 6 \\
\hline Salim, Robert & 1 & 1 & 0 & 5 & 0 & 7 & 6 \\
\hline Monsour, Doug & 0 & 0 & 0 & 5 & 1 & 6 & 6 \\
\hline Garrard, III, Henry & 3 & 1 & 1 & 5 & 1 & 11 & 5 \\
\hline Chaffin, Eric & 1 & 0 & 0 & 5 & 1 & 7 & 5 \\
\hline Love, Scott & 1 & 0 & 1 & 5 & 0 & 7 & 5 \\
\hline Burnett, Jr., Riley & 1 & 0 & 0 & 5 & 0 & 6 & 5 \\
\hline Mueller, Mark & 1 & 0 & 0 & 5 & 0 & 6 & 5 \\
\hline Copeland, Erin & 0 & 0 & 0 & 5 & 0 & 5 & 5 \\
\hline Goetz, Michael & 0 & 0 & 0 & 5 & 0 & 5 & 5 \\
\hline Hauer, Stacy & 0 & 0 & 0 & 5 & 0 & 5 & 5 \\
\hline Maniatis, Victoria & 0 & 0 & 0 & 5 & 0 & 5 & 5 \\
\hline Miller, Michael & 0 & 0 & 0 & 5 & 0 & 5 & 5 \\
\hline Robins, III, Bill & 0 & 0 & 0 & 5 & 0 & 5 & 5 \\
\hline Saunders, Joseph & 0 & 0 & 0 & 5 & 0 & 5 & 5 \\
\hline Cabraser, Elizabeth & 2 & 0 & 2 & 4 & 2 & 10 & 6 \\
\hline Aylstock, Bryan & 3 & 0 & 1 & 4 & 1 & 9 & 6 \\
\hline Climaco, John & 0 & 1 & 1 & 4 & 0 & 6 & 6 \\
\hline Placitella, Christopher & 0 & 2 & 0 & 4 & 0 & 6 & 6 \\
\hline Potts, Derek & 2 & 0 & 1 & 4 & 0 & 7 & 5 \\
\hline Alonso, Andres & 1 & 0 & 1 & 4 & 0 & 6 & 5 \\
\hline Clarke, Clayton & 0 & 0 & 2 & 4 & 0 & 6 & 5 \\
\hline Grand, Jeff & 0 & 0 & 1 & 4 & 1 & 6 & 5 \\
\hline
\end{tabular}




\section{TABLE A3: LEAD LAWYER FIRM APPEARANCES ON THE PlainTIFFS' SIDE IN PRODUCTS-LIABILITY AND SALES-PRACTICES PROCEEDINGS}

\begin{tabular}{|c|c|}
\hline Firm Name & $\begin{array}{l}\text { Firm Appearances in } \\
\text { MDL Proceedings }\end{array}$ \\
\hline Neblett Beard \& Arsenault & 18 \\
\hline Lanier Law Firm & 17 \\
\hline Seeger Weiss, LLP & 16 \\
\hline Levin, Fishbein, Sedran \& Berman & 15 \\
\hline Lieff Cabraser Heimann \& Bernstein LLP & 14 \\
\hline Beasley Allen Crow Methvin Portis \& Miles P.C. & 12 \\
\hline Motley Rice & 11 \\
\hline Weitz \& Luxenberg & 9 \\
\hline Ashcraft \& Gerel, LLP & 9 \\
\hline Zimmerman Reed & 8 \\
\hline Parker Waichman Alonso LLP & 8 \\
\hline Matthews \& Associates & 8 \\
\hline Climaco, Wilcox, Peca, Tarantino \& Garofoli Co., LPA & 8 \\
\hline Wagstaff \& Cartmell & 7 \\
\hline Robinson Calcagnie \& Robinson & 7 \\
\hline Hanly Conroy Bierstein Sheridan Fisher \& Hayes LLP & 7 \\
\hline Levin, Papantonio, Thomas, Mitchell, Rafferty \& Proctor, P.A. & 7 \\
\hline Anapol Schwartz & 7 \\
\hline Cohen, Placitella \& Roth & 7 \\
\hline Restaino Law Firm & 6 \\
\hline Johnson Becker & 6 \\
\hline Monsour Law Firm & 6 \\
\hline Law Offices of Daniel E. Becnel, Jr. & 6 \\
\hline Morgan \& Morgan P.A. & 6 \\
\hline Blizzard, McCarthy \& Nabers & 6 \\
\hline Aylstock, Witkin, Kreis \& Overhotz & 6 \\
\hline Foote Meyers Mielke \& Flowers, P.C. & 6 \\
\hline Oliver Law Group & 5 \\
\hline Saunders \& Walker & 5 \\
\hline Parker Waichman, LLP & 5 \\
\hline Reilly Pozner LLP & 5 \\
\hline Mueller Law & 5 \\
\hline Napoli Bern Ripka Shkolnik, LLP & 5 \\
\hline Robinson Calcagnie Robinson Shapiro Davis Inc. & 5 \\
\hline RodaNast P.C. & 5 \\
\hline Lewis \& Roberts & 5 \\
\hline Hagens Berman Sobol Shapiro LLP & 5 \\
\hline Hersh \& Hersh & 5 \\
\hline Law Offices of Riley Burnett, Jr. & 5 \\
\hline Douglas \& London & 5 \\
\hline Bernstein Liebhard, LLP & 5 \\
\hline Aylstock, Witkin, Kreis \& Overholtz, PLLC & 5 \\
\hline Blasingame, Burch, Garrard \& Ashley, P.C. & 5 \\
\hline Audet \& Partners, LLP & 5 \\
\hline Freese \& Goss & 5 \\
\hline Becnel Law Firm LLC & 5 \\
\hline Murray Law Firm & 4 \\
\hline
\end{tabular}


